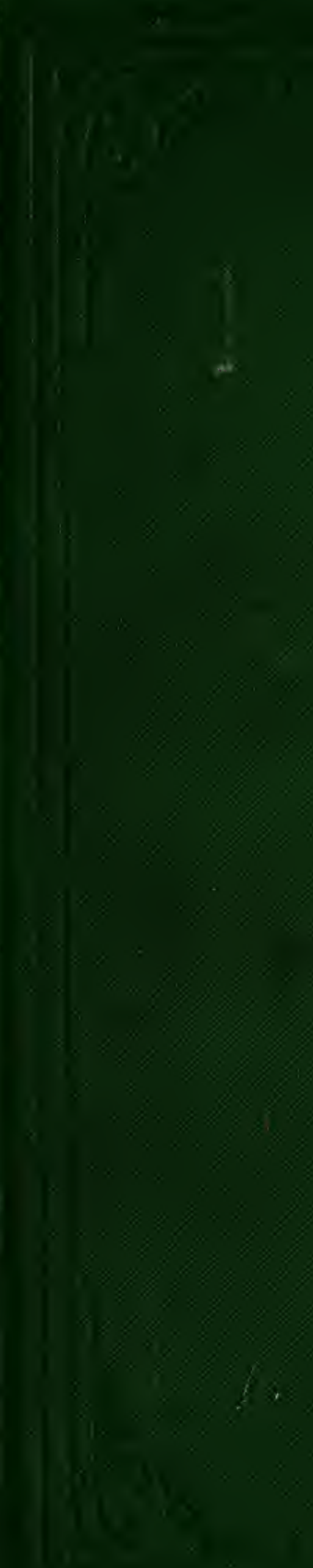




\section{$0 \times 5,85 \frac{260}{3}$}

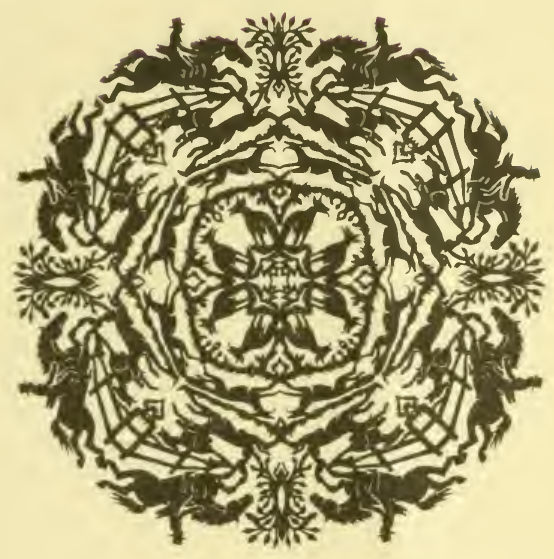

JOHN A.SEAVERNS 





\section{GUN, ROD, AND SADDLE.}

PERSONAL EXPERIENCES.

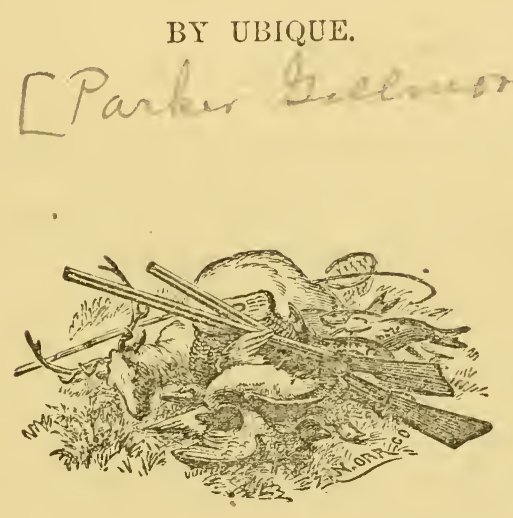

NEW YORK :

EXCELSIOR PUBLISHING HOUSE,

29 AND 3 I BeEkMAN Street, 
Entered according to act of Congress, in the year 1869 ,

BY W. A. TOWNSEND \& ADAMS,

In the Clerk's Oflice of the District Court of the United'States for the Southern District of New York. 


\section{ADVERTISEMENT}

The fondness the English gentry have for manly sports is proverbial, and this national taste has the best possible means of encouragement, in the adventurous life necessarily pursued by officers of an army which has its outposts in every part of the globe.

The author of this little volume in the course of his military service had, consequently, the opportunity and exceeding pleasure of indulging in alnost every variety of manly sport, the pursuit of which characterizes the accomplished gentleman.

His intellectual tastes led him in early life to the studies of natural history, and his field enjoyments opened wide the arcana of nature-so that he combined within himself the double satisfaction of the true sportsman and the intelligent disciple of nature.

After many years of absence he returned to London, and in the leisure courted after long ac- 
tive service, he prepared for the press the series of sketches which we present to orreader's. They were receired with great favor on their appearance by the best English and Continental authorities, and in compliance with a very decidedly expressed desire were gathered into a volume

Knowing how constantly increasing is the num. ber of "Sportsmen Naturalists" in the country, this volume is offered as affording refreshing reading and pleasing contrast to the constantly presented sensational literature that now prevailsthe publishers believing that there are charms thrilling and healthful in the wild and manly sports associated with the Gun, Rod, AND SaDdue.

The most popular and the most useful of living English naturalists was attracted by these sketches, and upon learning that it was proposed to issue a transatlantic edition, he expressed his approval in the following note:

"I much approve of MIr. Gilmore's book, and should be glad to hear that it is published in America." Fliaxk Buchlaxd.

New York, March, 1863. 


\section{P R E F A E .}

Havisg had the honor of holding Commissions under Her Most Gracious Mrajesty's Flag in two Regiments of the Line, as well as appointments in the Military Train, and in the Commissariat Departinent, I have, in the course of my professional duties, visited many parts of the world. A natural turn for observation of the habits of wild animals, and a dislike of a wanton destruction of life, has led me to make the best use of my opportunities, whether in the dense forests of Asia, the prairies of North America, the rivers of Japan, the highlands of Morocco, or the vast expanse of the mid-ocean. 
On my return to England, I became a contributor to the "Naturalist" and "Fishery" columns of "Land and Wrater." Permission has been kindly granted to me by the proprietors of that journal to republish my articles. I have, therefore, collected them into one volume, and trust that the now largely increasing class of "Sportsmen Naturalists" will derive benefit and amusement from my stories and adventures with "Gun, Rod, and Saddle." 


\section{O N T EN TS.}

Wolf Coursing........................ 11

Sharks Jumping at Food ............... 18

Seal Preserve $\ldots \ldots \ldots \ldots \ldots \ldots \ldots \ldots \ldots \ldots \ldots . . \ldots \ldots$

Otster Culture..................... 23

Auerioan Partridge (Ortex Virginiensis)....... 27

Aquatio Hare ............................ 32

SaLMon in JAPAN (Salmo Salar) ............. $3 \tilde{5}$

Wild-fowl Shooting in America............ 41 
Smooting in Batbart.................. 45

The Striped Bass .................... 48

Smooting in China .................. 53

Dudk Sirooting in America ............... 61

Ruffed Grodse (Tetrao Umbellus) $\ldots \ldots \ldots \ldots \ldots .66$

Gen for General Foreign Shooting.... ...... 74

Chinese Orsters .................... 76

Cuttle-Fish $\ldots \ldots \ldots \ldots \ldots \ldots \ldots \ldots \ldots \ldots \ldots \ldots \ldots \ldots$

The Syipe of Amerion (Scolopax Wilsonii) ...... 82

A Big Brok......................... 89

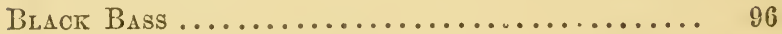

Hivts to Young Avglers................ 102

The Amerion Titorodgit-Bred............. 104

How to Capture Gray Muldet............. 115

The Prnnated Grouse (Tetrao Cupido)......... 118

Fisming at Gibraltar ................. 125 
Sporting Reminiscenses................. 129

Fisming off the Cape of Good Hope........ 134

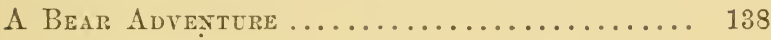

Fisinisg in Maine-Cirar or Trout.......... 142

Animal Life........................ 155

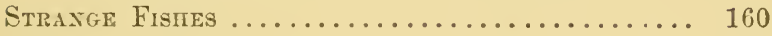

Веск-Анот.......................... 164

The Auericay Trotticg Horse ........... 167

Hists on Shootixg................. 187

A Chinese Mode of Fisming ............... 194

American Ruffed Grouse axd Partridge....... 196

The Power of a Sirark's Jaw ............. 201

Buack Bass and Meskallonge Fisming ........ 205

Liftivg the Traps.................... 213

Strange Fism ....................... 220

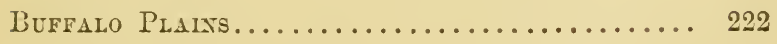


Rencounter mitr a Bear.................. 225

Ineas ox Fly-Fisimang................... 232

Strong Sпоoting ..................... 252

Ideas of Dog-Breaking ................ 254

Wilderatess Life $\ldots \ldots \ldots \ldots \ldots \ldots \ldots \ldots \ldots \ldots .269$ 


\section{GUN, ROD, AND SADDLE.}

\section{WOLF COURSING.}

Few of us have not experienced the excitement of a gallop over a good grass country, with the spotted beauties leading the way, getting over the ground at racing pace, while your mount is nearly hauling you out of the saddle with enthusiasm and inclination to make himself on still more familiar terms with the pack. By Jove, how reckless such excitement makes you feel! Fear is banished for the time being - all sense of danger is dispelled to the winds, and sooner than be thrown out, you would ride at a canal, or charge any height of timber. You may be old-yet for the time feel young: you may be blasé-you feel as buoyant as when you made your début. But it is far from the grass counties, across three thousand miles of water and fifteen hundred of land-far beyond the 
giant Mississippi, to the illimitable prairies of the Far West I wish you to travel, in thought, at least. Imagine an mbounded expanse of undulating land, covered with grass; here and there a sparse scattering of brush, with, perhaps, one or two lines of timber that mark the margin of some tributaries of some mighty river, and you have the landscape without entering into detail. What a place for a gallop! what a place for a buffalo run, or any other kind of run that will give your mettlesome nag an opportmity of showing his pluck and endurance. But take care, don't ride with a slack rein, keep your eyes open; all may look plain sailing from the distance, but on closer inspection you may come upon a densely populated dog-town, or collection of cayotte earths, each hole of which is big enough to use a Newfoundland in for a fox-terrier.

Two varieties of wolves are found numerous all over this elysium; game is abundant, and the marauder is always on its track looking out for the feeble or unfortumate. Skulking scoundrels are these members of the canine fraternity, and cunning withal; keen and successful hunters if necessary, but addicted to idleness; for if they can obtain 
their dimner at others' expense, they are always ready to sacrifice their principle, and sponge upon the first acquaintance. If you go out for pleasure, or with the desire of replenishing your larder, you are certain to be attended; you can not get away from camp withont their watchful eyes detecting you. As you rise one knoll you may observe the escort topping the last, and intently keeping all your movements under their observation. Full well do they know that if buffilo or deer fall before your rifle, on the refuse that you reject, they will find a bounteous repast; or if your hands and eyes forget their cumning, and a wounded unfortunate goes off, then the chances are that the whole carcass will fall to their share, and a gorgeons feast on tidbits ensue, for master Lupus has wonderful scenting powers, and, with the trail spiced with blood, he grudges no amount of exertion.

Again, the wolf is always in disgrace; he steals your game if deserted for a few hours to procure assistance to transport it to camp; he eats your lariat ropes, untying your animals, nibbles the flaps of your saddles, and keeps up an unearthly serenade through those hours that the tired sportsman is most disposed to rest in. Is it any wonder that 
he is unpopular, that he has no friends, and that he is considered a vermin of the first magnitude? The American wolf, although divided into many fanilies, those we have to do with are the large gray species, and the cayote or prairic varicty, the former of whom is a large, ill-looking savage, the latter less repulsire, seldom orer twenty-three inches at the shoulder, with more of the dog in his physiognomy, and a good deal of the fox in his nature. In all shooting excursions you will have itle days, a lay off for the more serions duties of the morrow, when guns are cleaned, bullets cast, powder flasks replenished, and wet or dirty clothes dried or washed. The forenoon having sufficed to perform these labors, a run with a wolf will be fonnd not a bad appetizer for your evening meal, or remorer of your little stifinesses and ailments, in the same way as a little exercise is necessary to the hunter the day after a long or hard run. To enjoy this pleasure to perfection you must be provided with logs, and there are none so suitable as the strongest stamp of greyhounds; more powerful ones that are addicted to grappling with the foe will get fearfully matuled, for the jaws of a wolf are almost as powerful as a liyena's, and consequently your limited establish- 
ment would be half the time on the sick list; with the greyhound it is different. As soon as you get a view, at him they go, and although the game is swift, still his adversaries are not long in ranging alongside, when a snap in the hams or loins immediately brings him to bay. Determined and numerous are his efforts to catch the nimble antagonists, who take precious good care to keep beyond reach. After a few moments of such skirmishing, the closer approach of the sportsman admonishes the wolf to be moving, and off he goes, best foot foremost; but his persecutors are in attendance. A hundred or two yards may be traversed, and again he is brought up standing from a similar cause; thus the game is played till the wolf is exhausted, and the sportsman gets sufficiently close to end the episode by a welldirected pistol-bullet through the grizzly marauder's cranium.

Spearing the wolf on horseback is also capital sport; but it takes a great deal out of your nag, for the scoundrel, while fiesh, will double almost as sharply as a hare, and from his wonderful lasting powers takes you over an immense distance, he invariably choosing the roughest ground. In this mode, also, you must constantly be on the qui vive, 
for if opportunity offers he will make either your horse or yourself acquainted with his grinders, and a snap from him will be a memento. In the neighborhood of Fort Rilsy an accident of this kind almost occurred to me. A large gray wolf jumped up before me, and as my horse was fresh, and the afternoon cool, I made up my mind for a run. Drawing my revolver, and taking my nag in hand, we were soon skimming the prairie at a slashing pace. After a mile of this work, I ranger along. sicle, but on sereral occasions, when about to press the trigger, the wolf wheeled sharply to the right or left, once very nearly throwing my nag on his head. More determined to draw blood from the trick practised on me, I was soon again at his tail; but the foe tried a new and quite unexpected ruse, viz., suddenly slackening his pace, and as I overshot him, making a most wicked snap at my off foot, which fortunately was protected by a heary cowhide boot; but the indentation showed that a lighter foot eover. ing would hare caused me to regret my prowess.

If ever you risit the Western Prairies you will not regret the trouble of taking with you some good strong greythounds; the rough seoteh dog I should prefer, for you will not only find them great promoters 
of your sport, wolf-hunting, but useful auxiliaries in pulling down wounded deer, as well as most watchful and trustworthy camp guardians and companions. 


\section{SHARKS JUIPING AT FOOD.}

Is "Land and Water," a correspondent who has been yachting during the summer, mentions the circumstance of a leg of mutton being lost which was hung over the side, and two blue sharks afterward making their appearance; doubtless they were there before the meat disappeared, and had an actire part in its disappearance. When cruising in the fore-and-aft schooner "Sunny South," on the Mosquito Coast, a few years since, the steward hung a roast of beef from one of the stern windows, and to his annoyance it was non est in the morning. The weather at the time was very calm, and it was consequently supposed that some forecastle hands had got down in the rudder chains and appropriated it, although how it was to be cooked withont discovery was dificult to know. Howerer, a second piece was about being hung out, which doubtless was to be well watched, when, as the piece of line was about to be maile fast, a violent pull was felt, and on the 
steward running out his head to find the thief, it was found to be a shark instead of a man; the fish had sprung at least three feet from the water to secure his prize. A friend of mine, while fishing with a deep sea-line, was néarly losing his hand through one of these blood-thirsty prowlers of the deep. The fish had not been biting rapidly, and careless from want of success, the hand in which he held the line was outside the gunwale of the boat and close to the surface; fortunately, he happened to cast his eye at the moment overboard, and just in time, for a shark, seven or eight feet long, was close to the surface, coming straight for it. On examining the head of a shark, it will be seen that from the position of the eyes, they can well see what is taking place above them, and in all instances where I have observed them take a bait, they always got underneath before seizing, turning on their side at the moment of laying hold. I never previously, till reading Mr. Buckland's remarks, saw it stated that a shark scented his prey; nevertheless, I have long thought so, and that their olfactory nerves are of the greatest acuteness and use in directing them to where it is to be found. On two occasions, once in the Southern Indian Ocean, on another, off the north 
coast of South America, near Los Rocas, although no sharks had been seen previously, they appeared about the slip soon after some of the most venturous had bathed. Again, I was on board a vessel becalmed, within sight of the volcanic rocks, St. Paul's and New Amsterdam. The captain kindly lent his gig to myself and companions to procure some specimens of Cape pigeons, Cape hens, and albatross. A great number of birds were killed, and whether it was the scent of blood or not, I can not say, but a white shark about ten feet long joined us, and remained by us till our return to the ship. He was afterward caught by using a Cape hen for bait. On examining the head of a shark, the snout will be found to project a long way over the upper jaw, and although there are no regular nostrils defined, such as will be found in the salmon or trout, there are a great number of minute orifices, doubtless intended for smelling, and which duty I am inclined to believe they most ably perform. 


\section{SEAL PRESERVE.}

Novelties are universally run after, but who will try to adopt the following? True, it is not in the power of many; still some have the facilities. We have deer parks, pheasant covers, grouse moors, and rabbit warrens; still we have no seal preserve. I can fancy I see Mr. Frank Buckland looking aghast at the proposal, and exclaiming emphatically, "What! Give a home and protection to the destruyers of my darling children Salmo salar? Such a proceeding would be worse than sacrilege, and all the other abominable erimes known, taken collectively and jumbled up into one heap." Within easy ride of San Francisco, the eapital of California, is sitnated the Ocean House-a great resort, in warm weather and holidays, of the élite of this prosperous Pacilic city, for here at all times a fresh breeze can be inhaled, and, exeepting diring a calm, the grandest, largest wares seen, lashing with impetnous fury the precipitous towering clitt's of a wild, iron-bound 
coast. Close to the Ocean House are some rocks, and on these at all hours can be beheld numbers of seals. The Legislature of the State has, I believe, passed an Act for their protection, and so well does Mastel Phoca know his safety, that I doulut if he would not dispute possession of his demesne with any representative of gemus homo that had the temerity to intrule. The Californians are very proud of these pets, and well may they be, for they form a strange and most interesting picture, reclining in all attitudes, young and old, big and little, fiec from fear and happy in their security. Many of them have been named fiom some fancied resemblance to persorrs. One, the king in stature, and most savage and repulsive in physiognomy, bears the sobriquet of Benjamin Butler, of New Orleans notoriety. An old resident informed me that he remembers this reteran seal for years, and that his conntenance was a good index of his temper. At night, from the Ocean IIonse, you can constantly hear them hellowing, and old Butler's voice, from its depth and rolume, is easily distinguished from the others. I expect that San Franciseo for many years to come will be the only eity that possesses a preserve of pet scals. 


\section{OYSTER CULTURE.}

Wirn much pleasure, both in the United States and in England since my return, I have read a number of most interesting communications from Mr. Frank Buckland, II. B. II. Commissioner of Fisheries, and others in reference to oyster culture. It has long struck me that not nearly enough attention was paid by my fellow-countrymen to this unbounded field of operations and wealth, and if they still continue to neglect their opportunities after the ability and energy with which the columns of "Land and Water" have pointed out the means of prosecuting the good work, let the onus lay on their own shoulders, for truly they deserve it. It is a well-known adage, "that one man can take a horse to water, but an unlimited number can not make him drink;" the horse might not be thirsty, and there are excuses for his refusil. But dear Old England, with her immense population, is always hungry, and has always mouths to feed, and I feel certain that with the amount of 
admirable coast that our island-home has, this description of food, which is both wholesome and nutritious, could with due attention become so cheap that it would be within the reach of both rich and poor. I do not for a moment profess to an excess of knowlelge; but while sojourning in North America, where oyster culture has been studied and practically tested for many year's, the experience of some of the most capable persons in various sections of that country I learned, and they unanimously agreed with what I have so lately seen stated in your columns, that a warm summer is the great desideratum for a productive deposit of spat. In fact, I can see no other feasible reasons to be adranced by our transatlantic cousins for their well-known success than that the warm waters of the Gulf Stream run along their coast, and that they have intense, almost tropical, heat in summer-such, in fact, as we have had during the past season.

Your accomnts manimously agree that your deposits of spat have been most abundant this year; but if the heat should be less the coming one, and should the produce only be one-hilf, I am still convinced that the returus woukl be far more than sufleient to indemnify the outlay; howerer, if a 
difference of opinion should exist, the experiment is worth trying, which, if successful, forget not to give the praise to whom it is due. Of course a great number of our fellow-countrymen know the United States; some of those may have taken interest in this subject, and possibly are better informed than I am; still there must be a great mass that know nothing about the American oyster; to those, then, I will grive the benefit of my experience. From Massachusetts to Florida, with more or less abundance, oyster fisheries have been established, not only for dredging, but for cultivating. The result is, that this delicacy can be obtained at moderate charges even in the interior towns and cities, such as St. Louis and Chicago; in fact, there is scarcely a respectable table d'hôte eastward of the Mississippi, on whose bill of fare they are not to be found. In the Dominion, where the winters are proverbially severe, they are equally abundant; New Brunswick, Nova Scotia, Prince Edward Island, and the estuary of the St. Lawrence, have long proved themselves prolific in this respect; corroborative of the fact that if you can get heat, such as we amully have, it does not matter how severe the winter may prove, for the abundant reproduction of these bivalves. 
It has struck me that the Amerienn oyster may be of a different species from the English; the shape is not the same, and the flavor (possibly many will say this is prejudice) I think, if possible, finer. If they are, could not the home-bred species be benefited by introducing the stranger? Experiment would soon elucidate this, for the American, if packed with the hollow side of the shell down, in solid masses, can be kept alive for months; in fact I have been shown them thus stowed away in cellars, when they had been built in over ten weeks; what, then, would a voyage of ten days, under such circumstances, signify? The motion of the ressel might shake ont some of their moisture (on which they subsist), but certainly not all.

The pinna fisheries of the Mediterranean some year's ago used to be most abundant; from want of culture and the improvements in dredging machirery, it has lately sadly deteriorated, almost to nil. In , enlightened England don't let us follow the example of the improvident natives of Southern Europe, who, so long as they can obtain the dinner of the day, care not and think not where to-morrow's is to come from. 


\section{$\triangle M E R I C A N$ PARTRIDGE.}

(ORTEX VIRGINIENSIS.)

IF all our countrymen who have traveled abroad or sojourned in foreign lands had done so with their eyes shut, or if not keeping their orbits closed had refused to give their countrymen the benefit of their experience, a useless lot they would have been, and England, as far as progression is concerned, would have been far behind her present adranced position. He who first introduced the idea of crossing our native horse with the foreigner, did an immense public service; he who introduced the old Spanish pointer, deserves the gratitude of every sportsman, for doubtless our present beanties, with all their speed and sagacity, have much of the blear-eyed, bad-tempered, pottering old scoundrels' blood in their veins; and still further, to foreign climes we trace the pheasant, the turkey, and so many more valuable animals, that to enumerate them would be 
tedions. However, I believe that there are quadrupeds, birds, and fishes, still strangers to our land, who but require to be known to be appreciated; and by placing the merits of any of them before the public, some one may be found sufficiently patriotic to make the attempt to natı̣ralize them.

Without more preamble, and to come at once to the point, let me say that in my humble opinion there is no bird more worthy of attention, and more deserving of the honor of introduction to our preserves, than the Virginian partridge, often misnamed in America quail. His numerous good qualities, together with bis deseription, I will to the best of my knowledge give, hoping it may be the means of yet seeing this little beauty ornamenting our fields, and adding brilliancy and rariety to the game-bags of our numerous enthusiastic sportsmen. The American partridge varies in weight from eight to ten ounces, is erect in his walk, very handsome in plumage, strong upon the wing, feeds principally upon grain, grass-seed, and ants, frequents indifferently brush, timber, or open country, is capable of standing great cold, is not quarelsome with other game, is very prolific, frequently hatching two broods in a season Moreover, an advantage which can not be too highly 
estimated, is that it never gets so wild as to rise so far from your dogs as to be out of gun-shot, a nuisance that all are so well aware of in our home-bred bird toward the end of the season. In fact, who that shoots regularly can not remember instances of our partridge disappearing over the far side of a field as soon as the sportsman had entered it? Now, in years of experience in America, I never saw an instance of this kind; up to the commencement of the close season they would remain almost as tame as they were at the termination of the previous one. A reason for this may be that they seldom pack; only once or twice have I seen more than the usual number of a covey together, and then remarked that the weather had been unusually severe and stormy.

A peculiarity, however, this bird possesses is that in wet and slushy weather he will frequently, when disturbed, take shelter on the limbs of trees, from where, if flushed, they afford the hardest possible shots. This bird in the open is by no means easy to hit, for his flight is very strong and swift, and frequently irregular, but he does not go far, so that a good marker seldom has much trouble to refind him. Some persons are under the impression that this partridge is migratory; however, this is a mistake, 
for although they may wander from their breeding place, from constant attention, I am convinced that the change of quarters is caused from scarcity of food. On the edges of the dry prairies in southern Illinois, in early autumn, this bird abounds; in winter they disappear into the neighboring thickets and brush, for why? the prairies are constantly burned at the end of the season, and consequently starvation or change of residence is their alternatives. In one section of the country that I resided in, a great portion of the prairie land was too wet to burn, and many a heavy bag I obtained late in the season, even when the roots of the grass were submerged in ice. My dogs, which I invariably broke upon them, seldom made mistakes, and never do I remember a covey departing (except the pointer or setter had run into them coming down wind) without getting at least a barrel into them. I believe these birds are equally adapted for naturalization into either England, Scotland, or Ireland, and with other varieties of game they appear to agree well, for I have on several oceasions killed this partridge with one barrel, and the ruffed grouse with the other over the same point.

As a table delicacy I know no greater; for weeks 
I have constantly had them at both breakfast and dinner, still without becoming satiated, and there are very few varieties of game could stand a more severe test. Their note or call is remarkably melodious, and in the spring or pairing time, when they are numerous, you can hear their sweet voice all day long, and in every direction. I have always regretted that no one has thought of introducing this little stranger, and nothing could afford me greater pleasure than to be the medium, for I feel perfectly confident that neither would ever have occasion for regret. 


\section{AQUATIC HARE.}

Is one of your late numbers allusion is made to a tailless hare. Of course, any new or but slightly known animals, their habits and modes of life, are subjects of great interest to both the naturalist and the sportsman; permit me, therefore, to call your attention to an aquatic member of the Lepus family, with whom I became acquainted during my sojourn in North America. A little before sunset, on a fine calm evening in March, I took my stand upon a bridge crossing a slough in the southern portion of Illinois, with the hope of killing a few wild ducks. 'The atmosphere was so clear and still that the birds were very late in visiting their feeding grounds. While impatiently trying to kill time, I saw something swimming in the water, and supposing it to be a common American musk-rat, and being desirous of a new tobacco pouch, I stealthily stole along the margin of the water, well bid in the flags, to endeavor to obtain a closer shot, for the musk-rat 
requires a tremendous deal of killing. However, having knocked over my game, in a few minutes my retriever laid it at my feet; but imagine my surprise when, instead of a rat, I found it to be a hare. I could scarcely believe my senses, but seeing is believing. Of course, I thought that the poor creature had been driven to water to avoid a foe; but before many days I shot several, and all in similar situations. The habits of this new variety I now made a study, and found that they were amphibious, sleeping in form on the edge of the morass during the heat of the day, and feeding, before sunrise and after sunset, on the different descriptions of water plants. Whether this hare was able to dive or not I did not ascertain, but that he is a most expert swimmer there can be no doubt. His size is the same as that of our common wild rabbit, but from his build being thicker he may possibly be heavier. IIis legs are short, feet large, ears small, and head very full and round; color dark-grayish brown, with scarcely any white upon the scut, and the fur exceedingly soft and fine. I frequently tested his qualities on the table, and can speak in the highest approval of the delicacy and delicious flavor of his flesh, which is much lighter in $2 *$ 
shade than that of any other of the same family with whom I am acquainted. The skin, which is rery thin, is easily removed from the carcase; but great care must be taken to prevent it getting torn. On inquiring, I found that this hare was well known by the squatters, and from them learned that it bred only once a year, generally producing two at a birth; and that the young at a very early age follow their mother in her sundry aquatic excursions in search of the delicate water plants that form their staple food. 


\section{SALMON IN JAPAN.}

(SALMO SALAR.)

No person, I am certain no gentleman, ever disputes the nobility of the salmon; he is an universal favorite with all, whether they be disciples of Isaac Walton or believers in Dr. Johnson's interpretation of the word "fisherman." As this noble fish is so universally popular, it may not be without interest to many of the readers of "Gun, Rod, and Saddle," to know that he is more universally scattered over this world than is generally supposed, and that he is a highly appreciated article of food, and of great commercial value, in countries so far distant from our island home that we may almost with safety call him a cosmopolitan of the northern hemisphere.

That the salmon was found in abundance in all rivers in America, from the Hudson River, New York, northward, all probably are aware; that he 
is extremely numerous in those rivers that flow north through the Mudson Bay territory, into the ice-bound Arctic scas, less are cognizant; but that he perfectly swarms in the streams and esturies of the North Pacific Ocean, many, I am certain, are ignorant. Yet he does swarm in those distant waters, until lately only known to whalers and fur traders, in such countless multitudes, that their arrival is looked forward to from season to season as the great event of the year-for with his coming, privations from hunger terminate, and an abundance of nutritious food is not only temporarily secured, but a hoard laid up sufficient to last through the protracted term of a rigorous northern winter.

When traveling in Japan, what was my delight to hear that salmon were numerous in these farored islands! Naturally I looked forward with avidity to the hope that I might be so situated as to obtain a day's fishing on the margin of one of its distant rivers; however, in this I was disappointed, but nevertheless had the fortune to make acquaintance with an intelligent Japanese merchant, who not only showed me numerous specimens of the genuine Salmo sular, but gave me abundant information regarding their habits, aud the method there pursued 
for their eapture. From observation, inquiry, and research, I am inclined to believe that the salmon, whether in the Atlantic or Pacific, seldom approaches nearer the Equator than the forty-first or fortysecond degree of north latitude. On the Atlantic sea-board of the State of New York, the Hudson River formerly was his southern limit; but alas, that stream is now totally deserted by these valuable visitors, the result of weirs, or the indiscriminate pollution of the stream with the débris of saw-mills, chemical filth from manufactories, \&c. On the eastern shores of the Pacific the same parallel will be found the southern boundary of this fish; while on the coast of Japan, Tartary, and Siberia, his haunts are marked by the same line of demarkation.

From the exclusive laws of the Japanese Government, I was unable to travel farther to the north than Ieddo, except it were to visit the port of Hakodadi, and consequently was prevented from obtaining a personal knowledge of the homes and resorts of the salmon; for although they are brought in immense numbers into the latter town for sale, they are not captured in the immediate vicinity. The Japanese salmon that I examined resembled more those on the Tay, in Scotland, from their 
cxcessive depth and thickness in proportion to their length. Their average weight appeared to be about twelve or fourteen pounds, yet several I saw would have turned the scales at thirty. The color of the skin was in all less brilliant than in our home acquaintances, possibly the result of transportation, the method of curing, or the shade and consistency of the water out of which they had been taken. However, the flesh was undeniably excellent, and brilliant in hue, and in no way inferior to those from our most appreciated rivers.

From my informant I found that the habits of their fish were identical with ours, and that so great were their numbers that they formed the staple article of food for the poorer residents of the northern portion of the Japanese archipelago; that they were captured principally by stake nets, set in the fluvial portion of the rivers; and that the English method of taking them with a fly (which I explained) was entirely unknown. As I could not have the honor of being the first of my countrymen to capture a Japanese salmon in the legitimate sportsman's method, I may have had the honor of tying the first artificial flies that ever were cast on a Japanese river; for so interested was my listener- 
and the Japanese are wonderfully intelligent, totally the reverse of the self-conceited, pig-headed Chinaman-that I dressed a couple of what I considered the most killing specimens, and which he promised to use, as instructed, on the first available opportunity.

An intelligent Russian officer whom I some months afterward met at Tier-tsing, in Northern China, and who had been for years stationed on the Pacific, gave me the most glowing account of the immense quantities of salmon that frequented the Amoor River and its tributaries, and his information perfectly tallied with that obtained from my Japanese friend. Now the mouth of this river, and the northern portion of the Japan group of islands, are in about the same latitude, and are only separated by about three or four hundred miles of sea, showing that most perfect credence might be given to both informants.

Fifty years ago, who would have thought of Englishmen going to Norway to fish? Possibly, as the world grows older, with the rapid strides of improvement in machinery and transportation, we may hear of fishing parties being organized for Japan and Siberia, and, in addition to the numerous 
splendid specimens of Salmo salar that now decorate Mr. Buckland's museum, we will see numerous beauties that once parted with their silver sides the blue waters of the Pacific. 


\section{WILD-FOWL SHOOTING.}

Is my protracted rambles about the world, I know no portion where this sport can be mnre thoronghly enjoyed than in America. I have always been passionately fond of wild-fowl shooting, and the bags that I have made in the United States and Canada have far exceeded those obtained elsewhere. As wild fowl are nearly all migratory by inclination, or are compelled to be so from the changes of the seasons, it is of great importance that you should visit the various haunts at the proper periods of the year. Howerer, the rule is, for successfully carrying on war against the web-footed families, go north in summer and sonth in winter. In June, July, and Angust, the wild-rice fields of the numerous labyrinth of lakes of Minnesota and the northrest territory, perfectly swarm with wild fowl, while in December and January they will be found equally numerous on the large bayous and lagoons that surround the mouth of the Mississippi. Of course, 
in the intermediate portion of country between Minnesota and the Gulf of Mexico, during the seasons of migration, splendid days' shooting can be obtained; but the stay of the birds is so short that it would not compensate for a special visit. Where thousands are to be seen to-day, not a dozen will be met to-morrow; but if you should happen in the spring and autumn to be in either of the States of Illinois, Iowa, or Indiana, when the frost and ice are breaking up in spring, or when winter makes its first appearance, you may with safety calculate on having some of the finest sport. A year or two since, when in Illinois in Norember, a sudden change took place in the weather, and although the morning was ushered in mild and warm, by noon it was snowing, with a gale of wind blowing from the north. From experience I knew that such a day was not to be wasted over the fire. I got on my shonting-ground with a very large supply of ammunition, and in two or three hours had to cease, as my stock was exhausted. My stand was in a field of Indian corn that had been gathered into shocks, from the back of one of which I took shelter from the blast as well as concealment. Never shall I forget the scene. The ducks came in thousands, 
sll flying before the wind, and if a dozen guns had been there instead of one, abundant work would have been found for all. On another occasion, in the same locality, two friends of mine killed, in two or three hours in the evening, and in an hour and a half the succeeding morning, eighty-four wild geese and thirty brace of mallard duck. In the spring of 1866, when in Iowa, the first day of thaw, I went for a stroll, scarcely expecting to find game; but when I got on the prairie land, I was perfectly astonished at the clouds of wild-fowl arriving from the South, some of the ponds being so densely covered with duck that the surface could scarcely be seen. These birds were all coming from the South, where they had passed the winter. If any of my readers intend to go in for work, and not object to roughing it, I should most decidedly say that the wild-fowl shooting is good enough to justify a Western visit; but let him not be induced to keep in the vicinity of settlements; but let him and his attendants commence housekeeping on the margin of one of the northern Minnesota lakes, if in summer (remember one that produces an abundance of wild rice); but if the reverse season should be selected, the southern tributaries of the Mississippi will afford 
him abundant sport, and any of the hospitable Southern planters will deem it a favor if you will do them the honor of making their home yours. 


\section{SHOOTING IN BARBARY.}

There are a great number of gentlemen in England who can spare the time but not the money to rent, at the present fabulous prices, shooting at home. For the benefit of such I will state that capital shooting can be obtained at Tangiers, and that the expense of going and returning, including a stay of a month, need not exceed forty pounds. Gibraltar, your first stopping-place, can be reached by one of the Peninsular and Oriental steamships from Southampton, or by one of the numerous Mediterranean steamships sailing from Liverpool. The passage money by the former, to go and return, would be about twenty pounds, by the latter fifteen. From Gibraltar, feluccas almost daily cross to Tangierstwice a week formerly, and probably still a steamboat with cattle does the same. The fare for this portion of the journey should not exceed a couple of dollars, and a good hotel will be found on arrival, where I have resided, at the rate of one dullar yer 
diem. Safely established under the guardianship of the hostess, you can obtain all desirable information, and a guide if such you deem necessary. An hour's ride from the town, going inland, will bring you upon splendid ground, either scrubby brushwood, covered slopes, or open grass and palmetto plains. The game principally found is red-legged partridge, which, contrary to our home experience of the same gentleman, here lays well to a dog. Hares are also plentiful, snipe, plover, and the lesser bustard not uncommon. Just beyond Cape Spartel there is a small river on which I have killed a great number of duck, and a mile or two farther on an immense swamp, known by the name of "the Lagoona," where snipe and wild-fowl may be killed in abundance, as well as woodcock and wild-boar. As the gates of Tangier are always locked at sunset, you have to hurry home at an inconveniently early lour, but if you do not object to roughing it, and prefer a long day and large bag to the luxury of a well-aired bed and comfortalle apartment, you can easily arrange so as to sleep at one of the numerous $A r a b$ villages or douàrs. Of course, to do this, you will require an interpreter, who should also perform both functions of cook and major-domo. But to one in- 
convenience you will have to submit, viz., fleas. They may not be the largest in the world, but for numbers and bloodthirsty proclivities I will back them against any others. The Moors are a fine, manly, handsome race, and invariably sportsmen. To a proficient with the gun they soon attach themselves. Sometimes I have been followed for hours by some of them, and a clever double shot would always elicit their admiration. However, there are some ugly stories in circulation of shipwrecked sailors and adventurous Europeans having received any thing but a hearty welcome; but this is directly in contradiction to my experience, for day after day, alone, I shot amongst them, and frequently slept in their villages with no other attendant than a youth from the hotel at Tangiers, and their conduct was uniformly kind and courteous. The weather also is delightful in autumn, and the country extremely pretty, while all around the town are abundant objects worthy of a visit on your idle days. In fact, I have little hesitation in predicting that the first visit will most probably not be the last. 


\section{THE STRIPED BASS.}

Turs fish is known the entire length of the seaboard of the United States, and is almost as popular as the salmon. There are many reasons for this; he is game in the highest sense of the word, fighting with the most determined obstinacy as long as his strength will permit, frequents alike the ocean tideway or river, taking generally with avidity the greatest rarieties of natural and artificial baits, and ultimately being fit food for the most fistidious epicure. By naturalists he is placed among the perch, and has been named Perka Labrax, an indignity which he is in no way deserving, for he is built on the beautiful lines of the salmon, possibly with a little more depth and beam, and his coloring has a nearer approach to that of the lordly Salmo salar, save that horizontally along his sides are placed several lines (generally seven) from the gills to the tail, and from which he doubtless derives his familiar name.

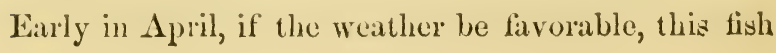


makes his appearance in the rivers en route to their spawning beds (from this date he becomes the objeet of attention to the pot-hunter, for I can not call the man who tries to capture fish in that state by the name of fisherman), where he remains for some time, probably over a couple of months. This duty performed, they return again to the coast, affording sport for a short period, then disappear to return in September and October in immense numbers, gladdening with their advent the heart of every sportsman.

Their size is so varied that they may be taken from the weight of a few ounces up to sixty and even more pounds, the heavier fish generally being captured late in the season; and woe betide the angler if unprepared he should strike his hook into one of the leviathans, for all his fishing paraphernalia will certainly receive so severe a shock as to render it for after use completely worthless, that is, the portion that is left with him. After sparning this fish does not lose its condition like the salmon, therefore his capture immediately subsequent is not nearly so reprehensible, the propagation of his species not injuring him to a noticeable extent, therefore, if he be fished for in the rivers after that 3 
duty is performed, nothing is so attractive for his capture as a gandy sea-trout fly; but the striped bass is not dainty, and many persons of experience persistently use with the greatest success a piece of white or scarlet rag tied orer their hook instead of the more complicated and expensive invention. Fishing in the sea, however, the shrimp is the most popular and gentlemanly bait, trolled along the surface after the manner of the fly, at which the fish break, similar to trout or salmon; still there are days when you can not thus allure them; and soft-shell crab, spcaring (a small transparent fish about the size of a minnow), or squid, have to be resorted to; even the spoon bait has been known to be successful when all other attractions have failed.

Although this fish amnually chooses a change from salt to fresh water, still it is not necessary for his existence, numbers having been experimented on by detaining them for years in fresh, where instear of losing flesh, they were pronouneed to have improved much both in size and condition. So exceedingly popular is the striper bass in America, that those watering-places in whose vicinity he is known to abound, receive amnually an immense influx of visitors attracted chiefly by the prospect of enjoy- 
ing this fishing. Even a club-house has been built, and a very large association formed of the principal gentlemen in and about New York, who spend a great portion of their summer vacation at this retreat, and as I have been informed by many of the members (some of them salmon fishermen of experience), that the sport they there have is only second to what they could obtain on Labrador or Canadian salmon-rivers.

I believe that this fish could be most easily intro. duced to our waters, and that he is well deserving of the effort, for he is very hardy, and I do not think so likely to be affected by the pollution that so many of our streams suffer from; they also appear to be immensely prolific, for traffic, netting, drainage, \&c., may have reduced their numbers, still they are to be found in great abundance eren in such crowded water-thoroughfares as the Bay of New York, Hudson and East rivers, that any person duly initiated in the necessary mysteries can, at the proper seasons, confidently expect a heary basket as a reward for his trouble, and that within sight of the numerous spires, store-houses, and busy thoroughfares of their handsome western metropolis.

Great and unprecedented trouble has been lately 
taken successfully to introduce salmon and trout to the southern hemisphere; with how much less difficulty could this fish be transported here; no tropic to cross, only one fourth or fifth the distance to traverse, and steamships to be found sailing almost every day of the week. Certainly this matter is worthy of consideration, for not only would thousands find amusement and health in their capture, but a wholesome and excellent article of food be provided for our immense population. 


\section{SHOOTING IN CHINA.}

"You may go to IIong Kong." This name is frequently substituted for another place currently supposed to be warmer, but at the same time in close proximity, for the soldiers used to say, on whose authority I know not, that there was only a sheet of brown paper between the two. Howerer this may be, Ilong Kong is a very warm residence during the southern monsoon, for the high hills that protect the back of the garrison at that season shut out every breath of air. For all this I never saw the thermometer over 98 deg. Fah. in the shade, so that according to statements of some of the late residents at Wimbledon, England in tropical heat can successfully compete with the world. But if the weather should be warm in this distant portion of Her Majesty's dominions during one portion of the year, the temperature is delightful when the northern monsoon sets in, and out-door amusements can by change be the more appreciated. The 
characteristic features of this island are a sucecssion of mountain peaks, in parts very rocky and barren, the balance of the hill-sides being covered with stunted brush. However, there are two valleys tolerably well corered with timber, viz., the Iappy Valley and Taytan Valley; in the former is the race-course, where annually is held a meeting, also the grave-yard, where worn-out man is deposited. A pretty spot is the Iaply Valley. The name, I think, not inappropriate, when we remember that it is the place of assembly, where crowds meet to enjoy the equine contests, or where man is laid to rest from all the troubles and ammoyances of this life when he has run his worldly course. The quantity of game to be found in the island is very limited, and consists of a few hog-deer, a few pheasants, some partridge (much resembling the black partridge of India), and at certain seasons quail and snipe; but the results are most uncertain, and half-a-dozen birds, all told, will be decmed a successful day's work. But if Hong Kong does not afford many inducements for the lover of the donble-barrel, the adjacent mainland, when you are acquainted with the localities, does; and if the reader will have patience, I will endeavor to give 
a sketch of an expedition, and the ground visited. Fancy yourself on a rattan-built wharf running into the harbor from the godowns at the back of the Danish consulate, a handsome lorcha of about sixty tons, taut-hauled up to her anchor, waiting impatiently a hundred yards from the shore for the moment of departure, while two or three sampans are incessantly plying back and forth, loaded with guns, dogs, portmanteaus, and good things for the inward man, ranging over the interval that exists between pâté de foie gras and Madame Cliquot. At last the finishing load is delivered, time is up, the blue-peter is hoisted at the fore, and at the instructions of our kind-hearted host, we descend into his gig, and are rapidly on board the larger craft. The wind, which is fresh, just suits; a few turns on the somewhat primitive capstan trips the anchor, and shaking out the immense mainsail, her head is pointed for the Cap-shee-moon Pass, the great high-road of traffic between Hong Kong and Canton.

As we leave the labyrinth of shipping and junks cf every nationality and shape, and draw farther clear of the land, our speed increases to eight knots. The pass reached, two or three tacks have to be 
made, when we stand direct for Castic Peak Bay, our destination; and what a pretty spot it is, sheltered from the cold winds: both grass and shrubs grow in luxuriance down to the elge of the water, while at the head of the bay is situated one of those quaint joss-houses, of architecture peculiarly Chinese, imbedded in a grove of banyans. The country around is a succession of rolling hills, gradually gaining height as they recele from the bay till they reach an elerated rocky ridge of most irregular outline, one portion resembling an old castellated ruin, from which, doubtless, this placid bay gains its name. When within a hundred yards of shore, "let go the anchor" was given, and we swung round and surveyed our shooting-gromed with satisfaction expressed on every countenance. The day before our party started, information had been brought by a cooly that the quail, in their regular autumnal migratory flight, had arrived; and scarcely had we progressed inland a hundred paces before the dogs were standing, and from that moment, till dark, the time for loating was eren grudged; the quantity that we brought to bag I forget, and consequently fear to make a statement; but this I know, it far exceeded our most sanguine 
expectations. The country around here appears at no late date to have been eultivated; but whether the peaceful tiller's of the soil had desisted on account of the neighborhood having obtained a very bad reputation for piracy I know not, but our experience in England tells us how fond these little migratory beauties are of haunts that the plow has ceased to turn up. Next morning our range took us farther inland, the quail still were abundant; but as we got to the upper ranges, where a dwarf palmetto flourishes, the Chinese partridge was found. This bird has a very strong resemblance to the black partridge of India in plumage, but exceeds it in size; never is found in coreys, and lies extremely close to a dog. Time after time I have walked up to a point, quartered my ground, or headed my dog; still no bird was visible; believing it to be a false alarm, I have been on the point of giving up the search, when whirr, the wily bird would rise, and go off like a thunderbolt. In all my experience, I know no other whose flushing makes such a commotion, or whose flight is so rapid.

This bird is not very abundant, and is called by the Chinese Cha-coo, doubtless from its note, which much resembles these two syllables when whistled. $3 *$ 
Four or five brace of them in a mixed bag is considered extra luck; still I have killed within the space of two hundred yards three couple, each bird flushing singly and apart. About midlay we reached a Chinese village, imbedded in trees, with a considerable cover lying backward from it. After lunch we beat it, and three splendid pheasants were our reward. The pheasant of sonthern China is truly a regal bird in comparison with our home-bred introduction. They weigh one-half more, and their flight is so rapid, that if the sportsman, in a cross shot, does not shoot well ahead, his game bag will long be kept ignorant of their weight and dimensions. Two or three times during the day I was frightfully fooled. The dogs were standing stiff as a fence-rail, and, of course, something extra was justly expected, when, what do you think? a birc that feeds on snakes and lizards, lumbering in flight, and of gross plumage, was flushed. In the south of China, this species is known as the crow pheasant, his size and long tail having doubtlessly gained the latter portion of the appellation; but on inspection, no one can help wondering at the indignity the bird of Colchis has suffered in haring such a brute bear his patronymic. For my own part, I 
think this filthy-feeding bird is of the jay family. During this day's work, sereral painted quails were baggged-a truly beautiful little bird, smaller than his namesake, but swift on the wing, and more delicate, if possible, on the table. Still they are so small, and the brilliant feathers so delicately pencilell, that I never cease to consider their death as an unnecessary slanghter.

Time flies on rapid wing; I had only three days' leave of absence, so that one day more was only left; duck and snipe shooting I have always had a passion for, so when we arose in the morning, not much refreshed with sleep (for the cowardly Chinese coolies kept constantly sounding the alarm of Lally-lunes-anglice, pirates-which kept turning out the whole party, revolver in hand), we determined to derote our last day to this sport. A wide expanse of distant marsh and paddy fields was our beat, and well it was that such a decision was come to, for we truly had some splendid shooting. Several ducks, a host of bitterns of every size and color, and innumerable snipes, composed our bag, the painted variety of the latter being very numerous. Although this is a handsome bird in appearance, he is sadly behind the common snipe in sporting requis:tes, 
being heary and slow of flight, seldom wild, and very inferior for the table. That night we beat back to Hong Kong harbor, while the stentorian lungs of one of the party, and the key-bugle notes of another, awoke the slumbering echoes of the neighboring hills, and astonished the celestial seamen, who passed on their various missions, with what "all that bobbery could be."

Castle Peak, from what I have said, can casily be found by any of the sportsmen at the distant garrison of Hong Kong; but there are numerons ather shooting-grounds as good, and scarcely farther distant, viz., the Shangmoon Valley, at the top of Pirates' Bay, the covers at the top of which always harbor pheasants; the far side of Meer's Bay, after crossing the Kowloone Ridge, have aftorded mo many days' excellent sport; and the nearest end of Llama Island to Victoria, about two or three hours' sail from the Barracks, if occasionally visited, will yield ample remuneration for a few hours' work. 


\section{DUCK SHOOTING IN AMERICA.}

IT may not be uninteresting to sportsmen to have an account of what sport they may look forward to if chance or intention should place them on the prairies of the Western Continent. It has long been my belief that Nature had strongly before her the wants of the rotaries of field sports when this farored land was constructed, for the abundance of indigenous food, the variety of corer, the distribution of water, and the salubrity of the climate are such, that probably in no other portion of the globe similar happy combinations ean be found; and, as a result, the abundance of game falls not one iota behind what might be expected. In wild-fowl shooting there are two desiderata on which success depends: first, suitable weather; secondly, the gunner being clothed in surtable colors. Faring both the abore advantages, please to imagine yourselves, on a cold, blustering afternoon, a few flakes of snow falling, and a strong presentiment of a severe frost before 
morning, situated among the withered leaves of a persimuon bush, on the elge of an interminable slough, in the eenter of one of the western prairies. In every direction that you cast your eyes, ducks will be seen, flock upon flock, while single birds, like an army of skirmishers, dart here, there, and everywhere. Mrving arranged your shot, powler, caps, and loading-stick, as most convenient-that is, provided you shoot with the muzzle-loader, and I am still old-fahioned enough to believe it the hardest hitter-for every moment is of value, look out; you will not be kept long waiting ere such work commences as you selitom or never previously enjoyed. Your situation, half up to your knees in slush and water, may not be conducive to health, but all the inconvenience is more than overbalanced by the excitement of the moment; and what will not a man endure, if possessed with true sporting proclivities, to gratify his passion, and does he not consider himself more than rewarded by the possession of a heary bag, alike evidence of his skill and hardihood.

On the afternoon of November-_ I started for my blind; the weather was such as clearly foretold the sport to be anticipated. My hardy mustang soon brought me to the scene of operations, and, 
after attending to his creature comforts, I was stationed in my blind, a few corn-stalks and grass having been alded to the withered foliage of the bush I had selected, the better to screen me; further, I had ticd a bunch of prairie grass around my cap, to assimilate it more to the color of the cheerless landscape; at my feet was an old and true friend, a setter, whose perfections in the hunting-field, or retrieving by water I nerer saw excelled. At first the sport was but languid, only an occasional duck passing within range, so that after an hour only four or five mallards had been brought to bag, but as the day adranced and the weather became more inclement, I had less leisure to ruminate and take note of the passage of time. By four, P. x., the ball had opened in earnest; if I had had two gurs and an attendant to load, still they would not have been idle. First come half a dozen mallards sweeping along in front of the blast, the pace terrific ; about forty yards off they pass to the left; with intuitive knowledge the gun comes to the shoulder and eye, and at the correct moment the triggers are pressed; good two yards in fiont have I to shoot, and my judgment is correct, for a bird topples over to each report, while the survirors rush upward with unaltered speed, take a 
sweep round to find from whence comes the danger, and, disliking the neighborhood, start for parts unknown and less to be dreaded.

As I hastily sent home my wads orer my shot, keeping an eye all the time to windward, what is that ever-changing cloud I see, reminding one of the reflected light that glances off the backs of a flight of gray plovers? By Jove, they are bluewinged teal! On, on they come, occasionally rising or swooping downward as fincy directs, In a moment they will be here-for your life don't move; even depress your eyes so that the rim of your hat will prevent the leaders secing them. At last they are within range, and each barrel's course is marked by a lane of birds, whom the shot has caused to alter their forward movement. As night approaches, the pintail and butter ducks put in an appearance, and without cessation your gun plays its part, the pile of game at your feet is becoming enormous, and Beau is never idle for a moment. As darkness increases, you think of going home, still linger for one or two more shots. Now you can only see the birds on the wing that are between your sight and some clear spot in the sky, but around you on the water are thousands. As every arrival is greeted 
with a lond quack, quack, frequently so close at hand that you start, almost believing that one of your victims has come to life. But hark! what is that honk! honk! Geese! I can't go till I dust some of their jackets. As none of all the webfooted tribe are so wary, extra precaution is necessary. At length you see a massive dark line against the sole clear portion of northern sky remaining. Would that heavier shot were in my gun. Onward they come, slowly and eantionsly; waiting till they are nearly perpendicular, I play my part, and the heary splash on one side and thud on the other clearly states that two are down, one in the water and the other on shore. With such a finale you cease, nor is it too soon, for I really believe that if you were to remain after darkness you might receive an injury, as the birds, no longer dreading a foe, rush about in the most reckless way, that I have felt quite a relief at getting out of the marsh without a mallard going at express speed coming in contact with my cranium. On the night in question twenty-eight brace of ducks, two geese, and three brant was the bag-good sport, as all must agree, for three or fuur hours' shooting. 


\title{
RUFFE GROUSE.
}

\author{
(TETRAO UMBELLUS.)
}

Is "Land and Water" of May 30th, I have advocated the introduction into England of the American partridge (Ortex Virginiensis), having perfect confidence in their being most suitable birds for naturalization, knowing them to be almost perfection in sporting qualities, and very superior as additions to the larder; but with all my partiality for that little beauty, I will presume upon your space and good-nature by mentioning the claims of one of the grouse family, that equaily deserves honorable notice and the attention of those persons who may be desirous of having a greater variety of feathered game than at present is to be foml. The ruffed gronse (Tetrao umbellus) must not, however, be confused with the pinnated grouse (Tetran cuppicts), for although both have a great similarity in appearance and size, their modes of life and 
choice of quarters are totally dissimilar, the former being found among timber or brush, or in its immediate vicinity, while the latter chooses the open grass-covered prairies, perching upon trees only when the winter is very severe and the ground covered with snow, and. then making use of such trees as are always to be found standing alone, and sparsely sprinkled along the margin of these immense western savanuas. Both these varieties are splendid birds, but the characteristics of the ruffed grouse make him much better adapted for a residence here, and so strongly am I disposed in their faror, that I believe if once introduced they wonld as soon as known outrival the pheasant in popularity, being much hardier, swifter on the wing, lying better to dogs, disinclined to run before flushing, requiring the quickest and straightest aim to bring them to bag, nor are they much inferior to the oriental favorite in beauty of plumage.

The ruffed grouse a little exceeds the red grouse in size, being almost eighteen inches in length, is very handsome and upright in form, of a beautiful rich chestnut-brown color, variegated with gray and dark spots, and pencilings on the back, breast, and neck. The tail is gray, with a black bar across it 
near its termination, and is generally carried open like a fan. On the top of the head there is a slight crest, and down each side of the neck are curious fan-shaped tufts of glossy, black, velvet-looking feathers. In April these birds pair, but I should imagine from the seasons. in the northern portion of the United States and Canada being more backward than ours, if they were introdnced here they would do so a month earlier. They lay from ten to sixteen eggs, their nest, which is a very primitive one, being generally secreted in brush or under the shelter of a fallen log. They are most affectionate parents, and use the same artifices as the wild duck to draw away the intruders from the vicinity of their youthful progeny. This grouse has two distinct calls, one a soft, mellow, prolonged note, genevally used in gathering after the covey has been broken up; the other an extraordinary drumming sound made by the cocks in pairing season, and capable of being heard in still weather a great distance. The latter noise is eaused by the rapid vibration of the wings when the male is perched on a fallen tree or stump. Indiscriminately they live on a great variety of food-ants, şrubs, alder-berries, wild cherries, and grain being their farorite diet. Early 
in autumn, when the weather is fine, particularly in the morning and evening, they will be found in the open cultiration, more especially if there be rough ground with brush in the vicinity; but as severe weather approaches the woods will become their constant resort. In shooting the rufled grouse, great difficulty is always experienced in marking them. The flight, as I have previously said, is wonderfully rapid, and they have a method of donbling back in the reverse direction in which they started; howerer, as they do not generally go far (about three or four hundred yards), with patience, and a selection of the nearest irregular ground which has young timber upon it, or the densest brush that is in the vicinity, a second opportunity will probably be again found of bringing more of the family to bag. All over the United States and Canadia they are to be found, being generally known by the misnomers of partridge and pheasant. Where the country is wide and sparsely settled, they are sometimes stupidly tame, almost permitting themselves to be knocked down with a stick. Frequently, when trout-fishing in the wilds of the State of Maine, I have come suddenly upon them, when they would rise into the nearest tree, 
and remain with unconecrn watehing you, when, from evident curiosity, they would streteh their necks, and get into all kinds of grotesque attitudes, ancl so little would they then regard the report of a gun, that I have known pot-hunters kill quite a number of the same family by always shooting the lowest birds first. But when the ruffed grouse becones familiar with man, he is perfectly cognizant of the danger of being in his proximity, for although they lie close enough to shoot at, their color harmonizes so well with that of the ground that it is next to impossible to see them before they are on the wing, when such is their impetuosity that the timid, nervous, pottering shot, or the poacher with all his devices, would find it next to impossible to kill a single specimen.

In the undergrowth which springs up in that portion of the country where the timber has been destroyed by fire, in the States of Maine, New IIampshire, and Vermont, I found them very abundint, it being almost impossible to wander half a mile from camp or settlement without flushing a covey. Now the winters here are particularly long and rigorous, far exceeding in severity those of Scotland; still, the birl's natural hardiness prevents his suffering. In the Alleghanies and all the sontlern ranges of hills 
of the United States he is also abundant, where, if the winters are less serere, the heat in summer is sometimes excessive, proving that the ruffed grouse is capable of enduring great varieties of climate. The palate of the most fastidious epicure can not fail to be gratified with his appearance on the table, the flesh being extremely delicate, with a strong flavor of our red grouse. I have eaten them cooked in every conceivable manner, and whether it be simply roasted over a camp fire or forming a portion of an omnium-gatherum stew, they will be found alike acceptable. Although scarcity of food may compel this grouse to change his beat, still they are not migratory, as stated by some naturalists. This supposition has arisen from their being found in great numbers during summer and autumn on the scrub barren land, which they leave as soon as the more serere weather commences, for the shelter of the dense timber. A family of these birds I was acquainted with for a year. On their range there was an abundance of food and water, and during that period I could always find them, their home being a little hilly island in the prairie covered with timber and brush, and detached from any irregular land by several miles of grass. 
Some authorities have placed woodcock shooting first in the list, and called it the fox-hunting of those pleasures in which the $\operatorname{dog}$ and gun form the chicf accessories. As far as present British field-sports are concerned, I believe they are correct, but should the ruffed grouse be introduced, and they once experienced the suddenness of their rise, the velocity and irregularity of their flight, the uncertainty of their morements, and the beanty and size of this game when bagged, they would assuredly insert a saving clanse, or change their opinions in toto. Much as I have said in fivor of the American partridge, with equal ferror I can advance the claims of the ruffed grouse; still, they both are very different, but the nearest explanation I can at present think of, is that the former is essentially adapted to the requirement of the veteran sportsman, while the pursuit of the latter will tax all the strength of limb and impetuous ardor of our -younger enthusiasts; the one is game that will afford the most delightful pastime, similar to hare-hunting with beagles, while the other will demand in its snecessful pursuit all the energy of the highly bred, dashing, conrageous fox-hound. I doubt not many, I believe all, of the warm admirers of shooting, will agree with me, that there is a supe. 
rior pleasure in making a mixed bag, now a mallard, next a woodcock, perchance thirdly, a partridge, and so forth-loading your discharged barrel, scarcely knowing at what description of game it will be used. Xes, truly, constant novelty and change is a great additional attraction even in field sports, and with our demesnes, parks, and forests, inhabited by a goodly number of both these varieties, the ruffed grouse and American partridge, in addition to their present tenants, the cravings of the most insatiable ought to be satisfied; and at a very trifling expense and trouble these introductions could be accomplished. 


\section{GUN FOR GENERAL FOREIGN SHOOTING.}

Tuere is no gun so generally useful for all deseriptions of shooting on the Ameriean Continent, in my humble opinion, as one of the following dimensions: viz., twenty-six inches long in the barrel, ten bore, and weighing about eight pounds. These dimensions are those of my constant and well-tricd old companion, and I have never met with a gun that could perform better. $\Lambda$ gun-maker in New Tork, who has deservedly a good reputation, told me that the best-shooting guns he had ever made were of these dimensions. If any intend ordering a $\mathrm{gun}$ for American shooting, I should further recommend that it be perfectly plain, and free from all engraving. As to choice between muzzle and breech loaderw, I shonld advise the former, as cartridges are troublesome and bulky to carry, and if the stock should run short, a considerable loss of time would occur (if you were on the confines of civilization) before a fresh 
supply could be obtained, but there is no place, from a trading-post to a hamlet, where the ordinary loose ammunition can not be obtained. Further, I am of opinion that the muzzle-loader has greater force, killing farther and hitting harder than the breechloader. 


\section{CHINESE OYSTERS.}

Iv my wanderings about the Chinese coast in scarch of game, I frequently came across immense banks of oysters, apparently no person's property; asd this is the more remarkable when we remember that there is probably no people on the face of the globe who have the same skill in rendering all descriptions of animal matter fit for table purposes. About thirty miles from Victoria, the capital of IIeng Kong, on the route to the entrance of the Canton River, is situated the entrance to a bay, which from the distance it runs inland is designated Deep Bay; the northern shore is one continuous mud-bank, on the upper portion of which are to be found actually acres of oysters. My acquaintance with this fact is not likely to be forgotten. A friend and I had been shooting wild fowl; a cripple had given us a long chase toward shore, and after we had succected in eapturing the bird, we found our return cut off, as the tide had reecded, and the 
sharp edges of the oyster shells become so close to the bottom of the boat, that if we had persevered in forcing her out, we should soon have cut a hole in her bottom. To get out and wade was impossible, as shoe leather would never have stood

- the ordeal, therefore there was no alternative left but to remain till the rising tide would float us ont; any thing but a pleasant resource, when time was valuable and shooting at a preminm. Slightly to console our wounded feelings, we attacked the oysters, which were excellent, and certainly demolished an immense quantity. Another time, in a pheasant-shooting trip to Meer's Bay, one of the minor inlets, where our loreha was anchored, had its margin densely covered with oysters, and the natives did not make the slightest objection to our using as many as required. From this circumstance it may be presumed that they knew no marketable value for them, for if a Chinaman can have the slightest grounds for fabricating an excuse for squeezing an Englishman, he is certain to do it. 'The only oysters that I have known exposed for sale in Iong Kong, and those only in very small quantities, when they are always purchased by the Europeans, are firom Amoy, and they are really 
excellent, for from appearance and flaror they can farorably compare with those of Colchester. For some years the resident merchants of IIong Kong have been aware of the fact, and like Shanghai mutton and game, the representatives of headquarters at the port of Anoy annmally send propitiatory offerings of their delicate shell-fish to their superiors. Some time since I was informed that a considerable shipment of oysters was about to take place, with the intention of making an effort to furnish Australia and New Zealand. with this luxury. Now instead of taking them from here, if the coast of China was selected, the probabilities of success in my opinion would be much greater, for the transportation distance can scarcely be over one-fourth of the voyage to Europe, and moreover, in farorable seasons any thing but a stormy passage might be anticipated, a circumstance not without considerable importance, for it is well known that the oyster can support itself a long time out of water on its own juice. If this hint should be arlopted, then I have neither wasted the ink and paper with which this is indited, nor my time in giving my readers the information that oysters are to be oltained in the Celestial Empire. 


\section{CUTTLE-FISH.}

There are very few inhabitants of the ocean which have so extensive a range of residence as the cuttlefish. In the Atlantic or Pacific he is equally at home, and in the western end of the Mediterranean he abounds. Wondrous stories are told of his savage proclivities, and in a shop in China I saw a picture in which one of this family was represented embracing a junk (which, judging from the size of the figures on board, must have been two or three hundred tons), and quietly helping himself to mariners, as appetite dictated. Why the Celestials did not get under the hatches I was unable to comprehend. That some of this species grow to an immense size, there is no doubt, as the whale is often found to contain dismembered arms and other parts of this their favorite food, which must originally have been component parts of monsters of gigantic proportions. To their belligerent disposition I can attest, for well I remember seeing one 
about fire feet across, attempting to seize a retriever who was paddling in the shallow water at the head of Rosia Bay, Gibraltar. During my residence in that garrison, there resided a señorita who, from her graceful carriage and pretty feet, never failed to attract attention; but she always wore her mantilla so disposed that her face could not be seen. Curiosity induced me to inquire the reason from one of her acquaintances, when I was informed that while bathing she had been seized by a cuttle-fish across the face, and that ever since an unsightly mark, where the blood had been drawn to the surface, remained. The cuttle-fish, although most repulsive to look at, is much prized on the coast of Spain as an article of food; they are frequently taken on the hook, but more generally caught among the rocks in shallow water with a gaff. A number of such in a boat doubtless would be considered unpleasant companions, for out of the water they can move with facility; however, this is not so, for the fisherman immediately on bringing him to the surface, with his hands turns the globe which forms the body inside out, thereby destroying all the power of suction. This is easily done, for there is an oritice on one side which the fingers can be 
forced into, and unless the fish should be of unusual size, no difficulty is experienced in placing him hor's de combat. I have often eaten them; their flesh when properly cooked being excellent. The best mode of preparing them according to my taste, is the following: first cleanse thoroughly by scalding, then rub body and legs with garlic, afterward cut the whole into small pieces, which fry in olive oil, one or two fresh plucked Chili peppers being introduced for seasoning. 


\section{TEE SNIPE OF AMERICA.}

(SCOLOPAX TILSONII.)

I NEvEr met a good shot who was not partial to snipe shooting; whether I am a good shot or no, matters not; but of all pleasures, there are few I so thoroughly enjoy as a day among the long bills. In the different portions of the globe that fate or luck has knocked me about, I have always been able to find snipe; so I an inclined to believe that there is no family more generally and universally distributed. But the prairies of Western America far outdo all others in the abundance of this description of feathered game. Scolopax Wilsonii is truly a splendid bird, so nearly similar to our own home beauty that the skillful naturalist is alone able to distinguish the one from the other; in habits, flight, and even eall, they are essentially alike. Ilow my heart warmed the first day I shot them, for the familiar cry that each bird uttered as he flushed, 
transported me back to days long gone by, to the society of old companions long under the sod, and a happy circle of relations, to whom it was erer my delight to exhibit the proofs of my skill.

The Wilson snipe-for by this name he is familiarly known all orer the American continentspends the winter months in the Southern States, principally in those that border the Gulf of Mexico; but as spring advances, they follow up northward the line of demarkation between frost and thaw, ultimately arriving in that boundless expanse which stretches northward from the Great Lakes to the Arctic Ocean. $\mathrm{Up}_{\mathrm{p}}$ in this remote haunt is their principal breeding-ground, although occasionally a nest may be found much farther to the south; but in all instances of such that I have been able to find, I have been induced to believe that either the male or female bird had met with an accident, preventing the following of the migration of his or her companions. What a beautiful lesson all may learn from this; how it should speak home to the human heart this attachment of the mate, who, sooner than desert a companion, forsakes for the time being his whole race, sare one, and foregoes eren following the journey dictated by nature. 
In sonthern Illinois, where I had the greatest amount of experience in killing this game, the arlvance heralds of migration generally arrived about the 10th of March. Much, of course, depended whether the winter was late or otherwise; but if a thaw had taken place, and a moist southerly wind had been blowing over night, the ground that yesterday you had tramped orer in pursuit of mild duek without seeing a single snipe, on the morrow would harbor thousands. Their journey being a continuation of short flights, they are seldom out of condition on arrival; and as they do not take up a permanent residence, little compunction is felt in shooting them. Out of the large number that I hare brought to bag, I do not remember a single instance of an egg, or other indication that pairing had taken place. The prairies of this State (Illinois) are generally burned late in the fall, or early in spring, to improve the succeeding year's grazing, leaving the surface of the soil entirely denuder of grass, except where moisture has prevented the burn taking effect. Over this, especially in the vicinity of sloughs, dwarf persimmon bushes abound, and there the snipe much frequent. A dog is not necessary here, for the game is so abundant, unless, 
perhaps, a good retriever, who must be under such control as never to attempt to leave heel, except when orlered by his master to recover a cripple. I further attraction to this sport, beyond the numbers that can be killed, is that few days pass on which numbers of teal, pin-tailed duck, or mallard do not assist to swell the size of your game-bag. From the advent of the first flight till the middle of May, additional arrivals take place, but after that date all disappear till the fall of the leaf, and gusty changeable weather fortells the near approach of winter. But the autumnal flight is never numerically equal to that of spring; still, if twenty brace will satisfy the sportsman, he can have that reward for his labor, provided he be a fair shot.

In America are to be found many excellent shots. By them the arrival of the snipe is looked forward to with much pleasure; but to the pot-hunter, the fellow who will shoot pinnated grouse on the ground, the duck upon the water, or erawl all day through brush to have a standing chance at a wild turkey, this branch of shooting presents little attraction. How satisfactory it is that there is at least one gamebird who can langh with derision at such pursucrs. At first. when the snipe makes its appearance, 
especially if the weather be wet and blustering, they are inclined to be wild; but much depends upon the amount of cover, and consequently shelter, afforded by the locality, but when the genial sun of spring shines with invigorating warmth, they will frequently lie so close that many will flush almost at your fect. When wild, their flights are long and rapid; when not so, they droop their wings, and frequently alight before a hundred yards have been traversed. However, this does not apply to the whole day, for toward sunset, possibly from haring by that time digested their last night's meal, for they feed principally by night, they invariably become wild, and more difficult of access. To be successful in making a heary bag of suipe, there is a rule which may be beneficial to the tyro to remember, viz., always to hunt down wind, or as much so as possible, provided always dogs are not used. The stronger the breeze, the more necessity for toing so; the reason being, that invariably snipe fly against the wind, and being flushed by your advancing on them from windward, the birds will whecl round to the right or left, and present an easy cross-shot, in their determination to pursue the desired direction. 
The migration of this snipe, as well as of the American woodcock, is peculiar; all appear to act independently of the other. Dozens may be seen to pass or light near you in the space of a few minutes, yet each bird is alone. Many an evening, after sunset, have I watched their coming, yet never saw two or more together. As a rule, these journeys by both the above-mentioned take place before sunrise and after sunset. This scattered mode of traveling, and the hour at which it takes place, are doubtless the reasons that none but close observers of nature witness these flights. By the end of May the migration of this snipe has ceased, and their summer quarters are reached, which are, as previonsly stated, principally north of the Great Lakes and the St. Lawrence; although not a few spend the summer in Nova Scotia, New Brunswick, and Maine. Early in June they commence laying their eggs, four in number, in a nest of the most primitive construction, it being simply an indentation in some trifling excrescence of the surface. The eggs, which are of a yellowish-brown color, blotched with dark markings, taper very much toward the small end; they are always placed in the nest with the larger end outward. As soon as the young are hatched, they 
leave the nest, and in six weeks afterward are almost full grown. At this age it is impossible to tell the Wilson snipe from our home variety; however, at any period the difference is very slight; and as they are quite as strong, swift, and erratic in their flight, and, moreover, to be found in immense quantities, ten or twelve dozen per day being no unusual bag in March, those who can spare time and money would, if fond of this description of shooting, find ample recompense by a visit across the Atlantic. 


\section{A BIG BUCK.}

Is the autumn of 186-, when traveling across the Grand Prairie, I got caught in the first snowstorm of the season. The vicinity was but sparsely settled, and from the thickness of the drift our charioteer lost his way, and after getting mired times without number, and enduring one of the most disagreeable nights ont of doors it is possible to imagine, we reached the village of Kent. Under ordinary circumstances it would have presented no great inducements, but the large wood fire that blazed in the bar-room of the diminutive tavern, after our protracted night of hardship, possessed such attractions, that I determined to lie over for a couple of days. The neighborhood was well stocked with game I learned the following evening, when I presented myself among the habitués, who commonly made this public-house their place of rendezvous after the toils of the day. No small portion of the conversation was in reference to a buck, who for years had constantly been seen, yet 
none of the heretofore successful hunters had been able to circumvent him. It was evident that this animal was of no ordinary size, as he was dubbed by all with the sobriquet of the big buck, and one regrular old leather-stocking; whose opinion was always listened to with the reverence due to an anthority, ventured to assert that he believed the bullet would never be molded that would tumble him (the buck) in his tracks. This extraordinary deer had almost escaped my memory, and I was resting over my next morning's pipe, and leginning to fear that my visit, was longer than necessary, for there was absolutely nothing to do but eat and sleep, unless the prices of pork, corn, or wheat had possesserl an interest; when a man from the timber land arrived with a load of wood, and held the following conversation with the mixer of mint-juleps, cocktails, etc. "Abe, have you e'er a shooting-iron that you can loan this coon?"

Abe having replied in the negative, and inquired the reason, was told that the most alfiestest big buck harl crossed the roarl about a mile off; and sone into the Squire's corn.* Quietly groing to my

* Every person in Western America is either Squire or Coloncl. 
bedroom, I unpacked my heaviest gun, a ten bore, in whom I have particular faith, and having noted the route that the teamster had come by, I followed the back track of his sled, and true enough found the prints of a very heary buck. The day was still young, myself in good walking-trim, and with an internal determination not to be beaten, except night overtook me, and very probably with the hope to show the neighbors that a Britisher was good for some purposes, I followed the track with unusually willing steps and light heart. To get into the corn-field the buck had jumped the snake fence and afterward doubled back, and as the wind did not suit for me to enter at the same place, I made a considerable detour. In my right barrel I had sixteen buck-shot, about the size that would run one hundred to the pound, and a bullet in the left. As the corn had not yet been gathered, and the undergrowth of cuckle-burs and other weeds was tolerably dense; I had little doubt but that I would get sufficiently close to make use of the former. An old stager like my quarry, I knew from experience would be desperately sharp, so with the ntmost caution I advanced up wind, eyes and ears strainer to the utmost tension. I had only got about a 
fourth of the field traversed, when I heard some roices right to windward encouraging a log to hold a pig. The noise of the men, dog, and porker, I concluded would start the game off in the reverse direction, so hurriedly retracing my steps, I regained the fence, got over it, and took my stand at an angle that stretched close to a slough which was densely covered with a growth of various aquatic weeds and mshes. In about five minutes after gaining my position, I was greeted by a sight of the beauty, who hopped the fence where there was a broken rail, and gaining the opening, for a moment halted, then tossing up his hear, offered me a fair crossshot nearly eighty yards distant. Pitching my gun well in front, I pulled the trigger, and well I knew not fruitlèssly, for he gare a short protracted jump, dropped his white tail close into his hams, and with an increased pace disappeared in the swamp.

Unless the wound was mortal, or so severe as to seriously incommode him, I was certain he would not be satisfied to remain in such close propinquity to danger, so after reloaling I made a détour to find where he had left this cover to seek one more retired. My conjecture was correct, for after travel- 
ing nearly half-a-mile, I found the familiar telltale track. The snow was in pretty good order, both for tracking and walking, and I did not let the grass grow under my feet. As yet I had seen no signs of blood, which the more thoronghly impressed me that my lead had made more than a skin wound. In about an hour's walking, I found myself on the edge of another slough, which I was hesitating whether to enter or go round, when I espied my friend, some way beyond range, going over a neigh boring swell of the prairie. Of course I cut off the angle and cast forward to where the view was obtained, and as I rose the swell, in the distance I saw my friend at a stand-still, evidently anxionsly scrutinizing my direction. Мy cap was of a very light color, so I concluded he did not see me, and my supposition was again correct, for after a few minutes he relaxed his pace, and turning at right angles, walked into a small expanse of dense rushes, interspersed with an occasional stunted willow. In deer shooting, if you suppose an animal severely wounded, never hurry him; if he once lie down, and you give him time to stiffen, you will not have half the trouble in his ultimate capture that you would have by constantly keeping him ou the 
move. So I practiced in this instance; carefully for ten or fifteen minutes I watched that he did not leave the cover; then having concluded that he had lain down, I quietly lit my pipe and dawdled away an hour more. Deeming that $I$ had granted sufficient law, I renewed operations and pushed forward; the track was very irregular in length of pace from where he had reduced his gait to a walk, and several times from want of lifting his feet high enough, he had scuffed the surface of the snow with his toes. An old deer-stalker will know these symptoms, a young one may without harm remember them. IIaving cantiously followed the trail three parts of the way across the corer, and almost commenced to think I would have done better by waiting half-an-hour longer, the buck jumped up within twenty yards, heading straight from me, when I gave him the contents a second time of the right-hand barrel in the back of his head.

The distance was too great to remore him home that day, so cutting a branch off a willow, I aftixed my handkerchief to it, and left this banner waving to denote possession, also to furnish a hint to the prairie wolves that they laved better steer elear. 'That 
night at the tavern bar in the most ostentatious manner, in presence of the assembled crowd, I ordered a team to be got realy in the morning to bring in the big buck; old leather-stocking, sotto voce, remarking, that I had not been reared on the right soil to be able to come that game. However, next morning, when I arrived with my trophy, the crowd congratulated me, while leather-stocking remarked, that he knew not what the world was coming to, by $\mathrm{G}$ - d, when a Britisher with a bird gun could kill the biggest buck in Illinois. In conclusion I would say, that in skinning we found that at the first shot one grain had gone through the lungs, while two more had lodged farther back. The gross weight of this deer was one hundred and eighty-four pounds. 


\section{BLACK BASS.}

Is advocating the introduction of birds, I feel $I$ have not yet performed my work; bear with me further, and grant me space to adrocate another introduction that, in my opinion, deserves the favor able attention of all lovers of the gentle artw Although I love the dog and gum, still I am equaily devoted to the rod. As every season has its beauties and its fascinations, so has every variety of field sports. On a glorious September day, what can exceed the pleasure of following a brace of welltrained, well-bred, high-couraged dogs over the golden stubbles? On a mild spring day, with a soft southwest breeze and dark clouds orerhead, can any thing be more delightful than following the tortuous course of a trout brook, taking from pool or stream the speckled beanties, or knee-deep in a rapid, boisterous river, first rising, now hooking, and perchance killing the glorious salmon? The whirr of pheasant or partridge is pleasant music; the voice of hounds 
is not less so; but the sereech of your reel, when first you are fast to a heary game-fish, is a song that even Patti herself ean not rival. For a fish to be popular among fishermen, he must have three requisites, viz., gameness when hooked, boldness in feeding, and, when he has yielded his life, be a fit feast for an epicure. All these requisites I claim for the black bass; and, therefore, presume to lay his claims for introduction before your numerous readers. There is no section of the world so intersected by rivers and lakes as the North American continent, and in nearly all these waters, from northern Canada to the tributaries of the Mississippi, and the various waters that flow into the Gulf of MLexico, the black bass is to be found. It matters not whether it be river or lake; whether the water be clear or muddy, stagnant or rapid; in all he appears equally to flourish. What splendid bomes could we offer him here! All our ornamental waters, though generally unsuited to trout, would be retreats eminently fitted to his nature; and the fishermen, instead of capturing such common pluckless fish as bream, tench, carp, or even perch, would have an antagonist that would test all his skill, the stoutness and endurance of his tackle, with that untiring, untlinching resolu- 
tion and headstrong energy which no other fieshwater fish of the same size, I beliere, possesses.

'The black bass is an extremely free feeder, and is canght in all the various walys used to capture trout. IIe rises freely at the fly; with minnow or worm, craw-fish, spoon bait, or almost any artificial device, he can be taken. On being hooked, generally the first effort he makes for freedom is to spring from the water. Look out, Mr. Angler, dip your rod in courtesy to him, for if you neglect the requisite salam, your acquaintance will probably terminate. When this device has failed, with a purpose and force alike surprising, he makes a rush for parts unknown, and not until every effort, every trick is put in practice, that is known to the fish family, can you get the slightest chance to use your landing net. I have frequently, after a long and fierce struggle, been about to place the net under him, but the morement was enough; though apparently exhausted, the fish took a new lease of life, and a further trial of paticnce was demanded before I could call the prize mine. In shape, the black bass much resembles a well-fed trout; but is deeper and thicker made, while the tail is remarkalle for its brealth. 'Their weight varies from one pound to five pouncls; 
yet on the Niagara River, near the village of Chippewa, I captured a splendid fellow, quite eight pounds; but I was then assured that I had reason to congratulate myself, for fish of such a size were far from common. The color, as in all varieties of fish, varies much. In clear rumning water they are generally a very dark green upon the back (much such a shade as the darker hues in mackerel), gradually getting lighter, almost to white, as you approach the abdomen; but in those Southern waters, which are strongly impregnated with alluvial deposit, and consequently turbid, the back of these bass is less brilliant in shade, while the stomach is not so clear a white. A still further advantage that may recommend them is, that they are in season when trout should not be killed. In spring they spawu, the exact time varying in different waters on account of season and position as to latitude.

If I may judge from the quantity of spawn the female contains, they unust be immensely prolific; for although the individual orum is small, the roe is very large in proportion to the bulk of the fish. From my own observation and inquiries, I believe that the spawn is from sixteen to twenty days in maturing, after being deposited, which would give 
ample time for its transportation across the Atlantic. I am further of opinion that, indiseriminately, gravel or soil bottom is selected on which to deposit the eggs; for many of the rivers and ponds in which I have captured this bass flowed through, or were situated in deep bottom-lands, where a stone, even as large as a pebble, would be difficult to find. One pond in southern Illinois I particularly remember; it covered a space of about thirty acres, with an average depth of about three feet, except in the southern extremity, where abont eight feet of water could be found. The bottom was entirely composed of mud; yet this pond swarmed with black bass. Lake Champlain, the St. Lawrence, and Lake Ontario (all who have visited these regions will remember) are remarkably clear, with gravelly or rocky bottoms, and each is a favorite haunt of this fish. I mention this to prove the better how universal a farorite and extensive his adoption might become.

A friend, once a resident of the Isle of Skye, and a well-known suecessful trout and salmon fisherman, harl a beantiful little lake, about ten acres in extent, on his estate, not many miles from Toronto, which he had stocked with black bass. In a few years 
their numbers so much increased, that in an hour or two, trolling of an evening, a dozen or more could easily be taken. This lake had neither outlet or inlet, but was supplied with water from springs in the bottom.

I fear it will be almost deemed heresy to place this fish on a par with the trout; at least, some such idea I had when I first heard the two compared; but I am bold, and will go farther. I consider he is the superior of the two, for he is equally good as an article of food, and much stronger and untiring in his efforts to escape when hooked.

By all means let us have black bass introduced. I feel confident this fish requires but to be known to be most highly appreciated. 


\section{HINTS TO YOUNG ANGLERS.}

I cas not hope to teach the expert, but I doubt not that there are many of the younger readers of this little work who may be assisted in taking a larger basket of fish than they otherwise would, by a knowledge of the following artifices, which I have often found most successful. In a clear, warm day, at the termination of the green drake season, when the trout can not be induced to rise at the artificial fly, I have frequently been most suceessful by practicing the following ruse, viz., having only a trail fly on your casting-line (which should be very long and light), make it slightly fast to a water-lily or other leaf; having marked where a fish is feeding, go up stream well above the plaee, and guide, through means of your rod, the leaf, so that it will pass close by the spot, taking the precaution of using a long line, and to keep as much out of sight as possible; when the leaf has reached the trout's haunt, by a slight strike disengage your fly from 
the leaf, so that it will drop in the water, and but seldom will the fish hesitate to rise, and on such occasions will yourself fail to strike successfully. Now for hint number two: when I have been unable to get a strike minnow fishing, I have stimulated the trout's appetite, by taking a worm and hooking it transversely across the center, so that when your minnow is put on, both sides of the worm hang on either side of his head. If fish reason, I suppose they thus argue: That fellow is going off with a prize; if he was not in good health, he would scarcely have such a voracious appetite. It's evident Nister Fisherman has played no tricks on this chap. So at him he goes, and tyro's basket becomes hearier by another fish. Not to keenness but to accident I made this discovery. I had fished most unsuccessfully for several hours, having changed from worm to minnow and vice versâ ; in one of these alterations, being careless from want of success, some wormi was left on the shank of the hook after I reverted to the minnow: the hint was not lost, and often afterward practiced. 


\section{THE AMERICAN THOROUGH- BRED.}

I THINk that few will disagree with me that horse-racing was established not alone for the amusement it affords, but for the encouragement of breeding a superior stamp of animal, alike capable of speed and endurance. Of late years the former quality has been the desideratum, and to so great a pitch has it come through light weights, short races, \&c., that the most useless, as far as utility purposes may be considered, are patronized for sires. The result is, what would have been deemed a race-horse a quarter of a century ago, is now thought a hunter at best, while what our fathers would have condemned as a weedy tucked-up brute, we, with our arlvanced views of civilization, call a race-horse. Speed for a short distance is what all harp after, and if stamina with speed ean not be obtained, the more useful quality is neglected, or entirely sacriticer, for a second less time in a mile race. Double the 
length of the race-make the course two miles instead of one-and which would be first at the winning-post?-or, still better, make the race three miles, and I much doubt if the weed would come home at all, leare alone save his distance.

Much injury is doubtless done our horses by rumning them long before they reach maturity. If you take a growing boy and orer-tax his strength, what will be the result? A wreck before he reaches manhood. So it is with our thorough-bred colts and fillies. They are forced forward like hot-house plants, prematurely reach maturity of form, when they are put to work trying even to aged animals, their muscular development being still soft and unset, and consequently unequal to the task, causing a broken-down cripple at the very time when, if permitted to have followed Nature's dictates, the poor creature would have rejoiced in all the perfections of beauty that charm the eye and tell of speed and endurance. What an every-day occurrence it is to hear of such and such a colt, immense farorites with the public from their success as two-year olds, being scratched? And why? In some closely-contested struggle, when flesh and blood was doing its utmost, under whip and spur, 
a yet further exertion was called for, and from the effort a strain or injury was receiver which time nltimately developed; and thus the flower of the stable, the hope of the owner, is thrown out of work, ultimately to descend through the gradations from pampered pet to over-wought cab-horse. True, it is not unfrequently the lot of man to undergo the same vicissitudes of fortume; but he invariably has some hand in altering his position. But the poor horse eams degradation through his endeavor to serve a selfish master too well.

The Americans are justly considered close ubservers and an essentially practical people, possessed with that energy which has long characterized this their mother people. From being originally thrown in a new land, where every effort and resomee had to be employed to raise them to the standard of older comntries, constant required attention to all the details of life, through numerous generations, has male them what they are, inferior to none, and far, far ahead of many European powers who can rate their existence back numerons centuries. It an early age the inherent love of Englishmen for horse-racing showed itself in America; and as might be expected, when the importation of thorough-bred 
stock took place, such judgment was employed, that the best animals that could be obtained in Eugland were only introduced. Unfortunately, however, racing got into bal repute, from the number of mauvais sujets it attracted, and although the Southern gentlemen did their utmost to cleanse away the stain, the fanatical puritanical spirit of many Northern States, tabooed the institution for years; thus it only had a partial existence, and but few horses were imported, and those always to the Sonth; but if the number was small, the selections were the more carefully made. Howerer, again a reviral took place, principally at first through the instrumentality of the late $\mathrm{Mr}$. Atchison Alexander, of Woodford, Kentucky, and latterly through the efforts of Mr. Jerome, of New Tork; so that at the present date almost every State boasts one or two race-courses, where as fine racing can be enjoyed as at home. From an innate love of the horse, I not only visited the majority of the American races, but obtained the entrée to many of the training and breeding establishments; thus gaining opportunities of forming opinions, that defective judgment alone would cause to be incorrect. One only of these establishments will I 
mention, because I was more conversant with it, not because it was either the largest or most replete with conreniences, - that of Mr. Sanford, in New Jersey, about thirty miles from the metropolis. This gentleman had a large number of all ages at work, all his own, for he was not a public trainer, but a person of affluence, loving the horse for his beauty and use, and running them with the hope that if they were entitled to the laurels they would bear them. In close proximity to his stables was his prirate training-ground, and the buildings were replete with every convenience that ingenuity, art, or money could supply. In looking over his pets, numerous descendants of imp. IIedgeford, Glencoe, Fnight of St. George, Ece, were fomd, all good ones, as some old memories will recall, and closely allied to the American-bred cracks, Lexington, Boston, Kentucky, and Asteroid. One thing that can not fail to strike the English visitors, is the much greater amount of stamina that all appear to possess orer our home-bred animal; and I am inclined to believe that this is not only show. I a!n aware that an English nobleman, probably the most successful of modern times on the turf, thought the same, and in consequence introduced 
a stallion. However, the importation did not turn out a success; but might he not have been injured in the royage, or the purehaser been wrong in his sclection? To successfully clear a rasper, there is nothing like going boldly at it; so, withont further preamble, I believe that the introrluction of a good American stallion wonld be beneficial to those who want to breed weight-carrying, fast, lasting horses.

Three or four miles is no unfrequent distance for a race to be run across the Atlantic, and it has always struck me how wonterfully game all appeared to finish, something like the Irishman's carhorse, a spurt always remaining to take your honor to the hall-rloor.

The Americans run their youngsters in their twoyear-old form, but the weights up are very light, the distances short, and the ordeal seldom required oftener than three or four times in a season; therefore the occasion of accident that our colts of the same age suffer from is materially reduced; in fact, if scratching in the United States was as frequent as here, where the number of entries does not exceed one-fourth of ours, they would have few or no horses show at the post.

For three and four year olds, the old system of 
heats is much in rogue; no bad one, let me say, for proving endurance; and here again I was much pleased with the gameness with which the contestants always re-assembled. It Seacancus, near New Tork, there is a bi-annual meeting; the establishment is superintended by a most hospitable, kind-hearted old Virginian, whose heart is in his work. I attended one of the meetings here, in which a son of Kinight of St. George won a heat race; it was so closely contested, and so gamely finished, that it even now warms my blood while I write of it. The winner was a dark bay, wonderfully compact in build, with a few gray hairs at the setting on of the tail, so common a mark of many of his fimily. What a charger, I thought to $\mathrm{my}$ self, he would make; nor do I believe I was far wrong. That day this horse proved himself a good one at long distances, and in heats, but he has also made his mile in one minute and forty-six seconds-reliable time. Now, this horse, Kinghthooul by name, if I remember correctly, had not been galloped off' his feet when a two-year old, or he never could have undergone successfully the rrial he endured on the occasion mentioned. It Paterson, New Jersey, I witnessed another closely 
contested heat race; the winner was a mare of $\mathrm{Mr}$. Sanford's, called Nanny Butler; she was an uncommonly well-put-together undersized nag, but with the most unsightly height of withers; five heats had to be run before the race was decided. The mare was ridden by a well-known veteran jockey, black as my hat; his reputation was great, and that day proved not without reason; still a good jockey can't land a bad mount first, although a good jockey can materialiy assist a good horse. At the start, the odds were heavy against her, and when she was declared winner, not the mare, but the rider, got the credit from the shrewd public. Why not have divided the praise? But such is too frequently the way of the world. Now, if Nanny had been run to death-or I will say had done the work of Achierement in her two-year old form-is it reasonable to suppose that she would have gamely and uninjured finished as winner the last and fifth heat of a two-mile-heat race?

I was in New York when the beautiful Jerome Park race-course was to be opened. K'entucky was then the acknowledged crack of Eastern stables, but away south of the Ohio River was his halfbrother, both being sons of the famous Lexington. 
Wonderful rumors had reached the Atlantic seaboard of what the Western representative could do. For a long time it was doubtful whether this great gun would put in an appearance. So Kientucky was backed at immense odds for the great eventthe Inauguration Stakes. At length a telegraph arrived, announcing the intention of $\mathrm{Mr}$. Alexander to forward his horse Asteroid. Public opinion became divided, but, as is generally the ease, drifted back to the home farorite. Astercid arrived a few days before the meeting, but unfortunately broke down; however, I availed myself of an opportunity to inspect him, and such a horse I have seldom looked at-a hunter up to fourteen stone across any country -yet there was not a single gross point about him. To what his mishap could be attributed, few could say; but I learned that, for an American horse, he had done an unusual amount of work in his younger days.

Kentucky, the most successful, and possibly the best horse that has been produced in America in modern days, although differing in color, is very much like Blair Athole in form, very showy and cocky in his action, and of most desirable temper. IIe has, I believe, only once been beaten, and then 
by Norfolk, a half-brother, who was shortly afterward transported to the Pacific slope; however, this defeat was to be attributed to (as I have been informed by a most reliable person) being out of condition. He is also a son of Lexington, and therefore claims relationship to Boston and Imp. Glencoe, ancestors to whom he truly does no discredit. I have seen Kentucky run several times, but always was he so immensely superior to his antagonists, that the race was quite one-sided. At Saratoga, I believe, on one occasion, his jockey pricked him, but I much doubt if such was necessary.

Lexington I have frequently mentioned; I much regret that $I$ forget his genealogical tree. As a sire and race-horse, his superior in the Western hemisphere was never prodnced. One performance was his running at the Great State Race on Mfetaire course, New Orleans, a four-mile-heat race, in which one of the heats was male in 7 minutes $19 \frac{3}{4}$ seconds-a performance his owner might well be proul of -for I can find no record of its being excelled; and it must be remembered that American time is always correctly taken by reliable persons, and published at the end of each heat or race. Lexington still lives, and is the sire of numerons progeny, many of whom I know, 
and all except one who shall be nameless, are not only fast, but enduring horses.

In conclusion, whether the American thorough-bred is as fint as ours would be difficult to decide; but that he is a most lasting, enduring, game horse, I can assert, a proof that the Americans have not forgotten, in the unirersal mania of the age for fistness, the desideratum endurance-the sine quâ non for utility. 


\section{O T TO CAPTURE GRAY MULLET.}

Ofter I have stood on the fluvial portion of a river and watched the gray mullet freely sporting on the surface. Numerous were the efforts I made to eateh these wily gentry with hook and line; but all overtures were rejected, and the fish preferred declining the bait to leaving their element. The gray mullet feeds principally on the surface, more particularly in warm weather, and as they are remarkably shy and gifted with but small mouths, with a preference to sucking in the bait, to freely swallowing like trout or others, the difficulties in the way of capturing them are obvious, and hence I will explain a method some might call poaching, but really no more so than trimmer fishing; in truth, it is much more excusable, for by the latter you capture fish that freely take the hook, while on the other hand you ensuare rogues that all your skill and patience will fail otherwise to bring to bag. Obtain a piece of flat 
cork about one inch in depth and the size of a regular ship biscuit; have a pouch made of coarse ganze, in which a slice of bread, the size of the cork can be placed, the gauze retaining the bread flat against the cork. From the margin of the cork suspend around the bread a dozen hooks, about the size of those usually employed in trout bait fishing, these hooks to be tied on strong gut, six inches long, and on the points of a few of them a small dice of bread should be placed. Armed with half a dozen of these infermal machines, and provided with a landing net, go in your boat above where the mullet are known to resort, drop your corks in the water, about eight or ten yards apart, scattering some crumbs among them, and let the tide or current float them to the fish, keeping the boat a good way in the rear. Don't be in a hurry, the fish will not keep you long waiting; each float will soon be surrounded, and when the mullet find that they can not carry away the bread wholesale, they will knock the floats with their noses, slap them with their tails, and in a few seconds you will have a prize on each trimmer, hooked by back, tail, or side. If the eaptives run large much sport will be enjoyed in retaking your floats, for it is wonderful how long a four or five 
pound fish will manage to avoid you. This method I have practiced often, both in smooth and rough water, and never without meeting with the greatest success, not only with the gray mullet but many other species. 


\section{TIE PINNATED GROUSE.} (TETRAO CUPIDO.)

Tue first pheasant I killed in China I thought the noblest game-bird that ever I had pulled a trigger npon, and truly he was a beanty; the plunage was in the most perfect state-the neck of the greenest emerald, the ring of the purest white, the tail the longest, and the different shades and tints of wings and bolly the very brightest I had ever seen in one of his species; moreover, he weighed nearly one-half more than any of the same family I had killed at home, and to add additional apprecution, the shot that brought him to the ground was a difficult one and at long range. For years the pheasant of the sonthern portion of China reigned paramount in my opinion; but a change has eome over my ideas, and now superlative before all others, I place two varieties of American game-hirds. That days of pleasme have I hat in the pursuit of pinnated grouse; what splendid bags have I mate, and on such grotind 
as gave my darling companion setters the rery best opportunities of showing their sagacity and careful edueation to the greatest alvantage. In my previous notice of the ruffed grouse (Tetrao umbellus), I have stated that I do not believe this bird (the pinnated grouse) so worthy of acclimatization as the last mentioned; and why? he disregards distance in his late autumual tlights; and therefore where shooting ranges are limited by bounds, unless the proprietors on every side would mutually agree for their introduction and protection, I fear that the labors of one landowner in introdncing and propagating them would be franght with dissatisfaction, as his neighbors would enjoy almost as much as himself the benefit of his expense and trouble. But for all that, the pinnated grouse is most worthy of our attention; he is truly a most noble bird, and affords the sportsman the best of sport, till the cold winds preceding winter cause him to pack, in the same manner as our red and black game, when their wariness becomes so great that naught but quick shooting and Ely's green cartridges are likely to help the laborer to produce a bag remuncrative for his toil. That this bird could be acclinited here there is no doubt, for he is capable of withstancling 
great changes of temperature; is not particular as to choice of ground as long as it is open ; and plenty of grain and grass seed can be obtained. Although his range is now principally confined to the prairie country of the United States, not being found in great numbers till the edge of the Grand Prairic is reached, still formerly he was found equally abundant all over the open lands; still, however, Long Island and the island of Martha's Vineyard possess some remnants, who long since would have disappeared but for the protection and care of the landowners in those places, who have endeavored to prerent if possible the extinction of this valuable bird upon their estates. I can not well imagine any place so bleak in winter as the scrub uplands of the two aforementioned islands, unless, perhaps, Mull and Jura on the Scotch coast. The bird that could with impunity withstand the rigors of the cold in the

- former could doubtless with impunity do the same in the latter. The pinnated grouse pairs in March, and generally produces from twelve to fourteen young at a brood; the chicks very early take to the wing, but their flight is weak and short until they are more than half grown. During the infancy of the family, the courage and artiliee of the parent 
bird to intimidate or draw off intruders is worthy of notice. At first she will fly toward you as if intent on doing you battle, but when this course has failed, she will retire, droop her wings, struggle on the ground, only just keeping beyond your grasp, always moving in a direction contrary to where her brood are hid, until parent instinct tells her that the children are safe, when suddenly on strong wings she will start for a distant flight. The facility with which the young secrete themselves is most surprising. Frequently have I got unexpectedly into the center of a family, when up they would rise like a flight of bees and as rapidly drop again; certainly you see the exact spot on which they have alighted - that tuft of grass you believe most surely contains one, but search as yon will, turn over carefully every blade, look well about the roots-all is useless, for no fledgeling will you tind.

At the commencement of the pairing season, particularly if the weather is calm and clondy, the male birds will be heard calling all day; their note resembling the lowing of a cow, which can be heard distinctly for orer a mile. At this time fierce-looking encounters appear to take place, but I am inclined to beliexe that their fights are all a sham, performed 
to show themselves to the greatest arlvantage before the admiring ladies who assemble around ; for I have never been able to find a maimed hero, and seldom more than a broken feather resulting from the contest. As the spring advances they restrict their calling to evening and morning, and by the time the brood is hatched, case it altogether. The peculiarity of the call of the males of this species is such, that onee heard, it is difficult to forget, particularly when softened by distance; it is produceed by forcing the air out of two orange-colored receptacles placed on either side of the throat, and which, when inflated, are as large in circumference as a min's finger, perfectly fiee from feathers mpon their surface, but hid when in a state of quiescence by fan-shaper bunches of hackles that completely corer them."

The pinnated gronse is about the size of our pheasant; however, they differ considerably, those birls that inhabit sonthern Illinois being at least one-fonth ?larger than those obtained in Minnesota, Wisconsin, and the northwest prairies. They are of a beatiful mottled brown and fawn color, frequently with white finger-marks on the upper portion of the wings and

* Tho most killino hackles for tying trout-flius. 
back, are feathered down the legs to the feet, have beautifully set-on small heads, with a slight crest, and bright yellow iris. When standing, their attitude is very erect, but graceful, while their flight is strong and swift, more especially late in the season. On being flushed, they invariably cackle, and the first flight, except of young birds, is always long. In the commencement of the season, and in fact as long as the weather is bright and mild, they lie remarkably well to $\log$ s; but as soon as severe and cold weather sets in, they pack and become wild. However, late in October, if you should hit upon a warm, summer-like day, the birds will lie so remarkably close between the hours of $10 \mathrm{~A}$. x. and 3 P. x., that marvelous bags can be made.

As a delicacy, this bird can farorably compare with any of the grouse family, but is dissimilar in one respect from all the others, for the sooner it is cooked after being killed, the more delicate and savory it will be found. Even the skill of Delmonico, in New York, the justly celebrated restaurant proprietor, with all his knowledge of cuisine, can not impart the flavor that the same bird would have harl from the hands of the most ignorant cook, provided it was served a few hours after it was killed. 
The pinnated gronse can easily be domesticated. Mr. Autubon, the naturalist, for some time kept quite a number in a walled garden, where they became as tame as domestic fowls; nor do I believe there would be any difficulty in transporting them across the Atlantic. To gentlemen stocking preserves, or desirous of being able to show a great variety of game upon their estate, I believe this magnificent nember of the grouse genus well worthy of attention. 
FISHING AT GIBRALTAR.

\section{FISHING AT GIBRALTAR.}

Dear old Gibraltar, much as thou art frequently railed at, I believe the faults are more imaginary than real. Englishmen are grumblers proverbially and truly, more particularly the untraveled specimens. Transport them once away from native soil, and nothing that they see or make use of is equal to what is to be had at home. I am almost inclined to believe that there is a spirit of discontent in the breed, for our cousins across the Atlantic, although to a less degree, are strongly pregnated with the same peculiarity. Why is it that you seldom find one who is doing garrison duty at Gibraltar who does not sigh for change; true! you, if a subaltern, have more guards to keep, and in the cool season an overplus of brigade days, still you have your hounds, who, althongh they do not kill whenever they meet, afford plenty of fun; you have numerous pretty rides open to you into Spain, and if a fisherman or shot, sport can both be obtained in the bay and 
over the straits in the vicinity of Tangiers quite as good as you probably enjoyed at home, unless you had the privilege of a well-stocked salmon river or carefully preserved demesne. Althongh I am certain this garrison is seldom without numerous followers of old Izaak Walton, yet I clare bet that few have essayed their art while there-why, I can not sayfor althongh I did constantly, I never met a companion, and more the pity; for fishing (that is, sea-fishing) is here to be obtained of the greatest excellence. The New Mole, where vessels obtain their requisite fuel, used to be a favorite haunt of mine, more particularly on those serene, romantic nights peculiar to the Mediterranean, when with my light fly-rod and a small brilliant artificial minnow attached to very light tackle, I used to capture dozens of a beautiful little fish, of the mackerel family, there called horsemackerel; true they were not large, seldom exceeling nine or ten inches in length, but then they were so game, giving as much sport as a half-pound trout, before you conld safely land them on terra firma; and when fishing for these resplendent little beanties, you wonld occasionally hook a monster, when your only option was to give him the butt, place a check on your line, and force the weak portion of your tackle to 
part. So often did this occur to me, that I determined to go armed for emergencies; and having obtained a most puwerful bamboo-rod and attached a salmon reel, with a sardine for bait, I determined to try the results, nor was I long kept in suspense; the rush came, line was given, but all of no avail, for the hopedfor captive refused to be taken, and the loss of hooks and leader followed. A dozen times I made the essay, and a dozen times the results were similar. What those leviathans were, I never knew with eertainty, but I always strongly suspected the ravisher to be no less than a dolphin (Delphinus Tursio). To possess a big fellow I found was impossible, so I stuck to the little mackerel, and revenged upon them at breakfast the next morning, the depredations of their seniors.

At Catalin Bay, where I had to serve the allotted period of imprisonment, I found the fishing even better than on the west side. When I was sent there, I should have liked to question the colonel as to the justice of his selection, but after all, the two months flitted by, and eren now I look back with pleasure to the simple, small Genoese fishing-rillage. Perhaps by chance there is a fisherman stationed there now; well, if so, I will put him up to the ropes. As you gro 
along southward from the village to visit your guards, there is a care. Passing through it you find a porthole, looking perpendicularly down on the Mediterranean. Then there is an easterly wind blowing, the surf breaks beneath in grandest splendor. From this port-hole, with strong tackle and plenty of fresh sar. dines for bait, you can take more fish in the course of the day than will suffice for your whole detachment.

Off Catalin Bay there is a bank, four good miles from land. Get the village fishermen to take you to it, and if fortune smiles upon you with the faror it did on me, you will cry before the night is over, "Hold, enough." The fish principally taken were a copper-colored bream, ${ }^{*}$ about two or three pounds in weight, and so numerous were they, that we never thought of drawing up our lines till we had two or more victims hooked; and how do you think we knew this? Simply in this way, one fish on, you only felt a direct tug, two or more a constant vibration, as if a party were squabbling over the line, and each endeavoring to take possession of it.

* Called by the Spaniards "Bissengo." 


\section{SPORTING REMINISCENCES.}

For some days I had had a terribly hard time of it. The ground had drunk its full-and to spareof snow-water, game was scarce and wild, and the scanty herbage that my horse and mule were able to obtain since we entered the plains was barely sufficient to keep them alive; still, good seventy miles more had to be traversed before I could reach the friendly shelter of the belt of timber that surrounded the Fork. If it had been autumn, I dare not have chosen this route, for it is a debatable ground of the Camanche and Arrapahoe, to whom a solitary white man would be so tempting a morsel that he conld not fail to be caught, and we will not say what done to; the very eonjecture is disagreeable. The severity of the late weather, therefore, was my safety; for red skins, no less than white men, dislike unnecessary exposure. Still I was convinced some stragglers must have lately visited the neighborhood, for the occasional head of game I saw was so wary that I concluded hunters bad lately 
disturbed them. One thing was very much in my favor-I was in the lightest of marching order, no pack of peltries or well-stocked kit had I, for a few pounds of bullets, a pound of powder, and my buffilo robe, were all my animals had for a load. How independent a fellow feels when all his worldly goods can be summed up in so few words. To keep as much in the nags as possible, in case speed might be required, on the look-out for any thing suspicious, with cautions, slow steps, I pursued my route to the eastward. Nothing occurred to inerease my watchfulness; in truth, I commenced to believe that I had unnecessarily alarmed myself, when, crossing a small water-conrse, on the edge of which was a sandy margin, plainly I saw the prints where three horses had lately passed. The forefeet of one of them was shor-a good indication. Still they might have lately been stolen from some distant white settlement, so all my previous alarm and caution were again reverted to. Inalf an homr afterward I heard the report of a rifle; but, as there was a roll in the prairie between me and the direction the sound came fiom, I could not see who hat fired the shot. In ignorance of what was to be seen beyond, it would have been madiess to have ridten to the 
top of the bluff; so, turning off to the right into irregular, broken ground, the effects of the previous year's heat, I hobbled my animals, and started cautiously to stalk my way to some high ground, from whence I might obtain a view of the surrounding country, taking care to keep myself between the suspicious direction and my beasts. I had not traversed over 150 yards, and was halting, the better to notice the most available cover for future progress, when first the head and shoulders, then the entire figure, of a man loomed o'er the top of the swell. Camanche or Arrapahoe I knew at once he was not-perhaps Osage or Pottawatomie; but what the deuce would bring them so many hundred miles from their own hunting lands? Howerer, as every thing in the shape of red skins is to be dealt cautiously with, I changed my caps and got into most convenient and uneonspicuous shooting attitude, determined not to throw away a shot, or, much less, give my supposed foe a chance of returning the compliment. That he was alone, being dismounted, I knew could not be the case; and as he was coming in the very direction of my fresh trail, which, if he was permitted to cross, he could not fail to discover, and, with the discovery, bring his whole 
party in pursuit of me, there was but one alternative therefore for me to adopt. Last year, in this very locality, the Indiaus had been unusually active; scarcely a gang of emigrants or traders who had taken the southern route but had lost members of their party; in several instapces neither sex nor age had been spared by these blood-thirsty marauders, so what could I expect if alone I fell into the hands of a party of braves on the war-path? True, my scalp-for it has long been ignorant of a scalp-lockwould scarcely be worth lifting, but then I did not want to knock under yet; and if so I preferred making a fight for it, as, I think, under the excitement, the process of being wiped ont is less painful.

By this time my stalwart apparition had approached within eighty yards; he was a noble-looking figure, without the slouch of the red man when hunting, and his step was as free and independent as if he had been shooting over a private manor. A big bug he evidently was, conscious of his own divinity, still no eagle's feather or characteristic mark of a chicf distinguished him; presently he halted, and threw his large gun across his arm, when I saw at once that he was a white man. Great was his surprise when he saw me leave my ambush; quick as thought his rifle 
was cocked and brought to the port, but I prevented him from further hostile demonstrations by a salute in mother tongue. Our meeting was strange, both took a pretty good stare, and then mutually mentioned each other's name, for we had met before, and where?-in no less distant a portion of the earth than in the realms of the Tycoon. A restless spirit, a crack shot, and passionately fond of field sports, the world was his demesne-and where game was abundant, there he would be found, whaterer were the dangers that surrounded it, laughing at hardship and privation, the bitters that make the sweets of life the more enjoyable by contrast.

Securing my animals, I accompanied him to the party to which he had attached himself; they had only lately left civilization, and through his interest my equine companions got a feed of corn, to which they had long been unaceustomed; the night passed discussing old friends, a flask of brandy, and a package of kill-a-kinnick tobacco; and when on the morrow I shook his sterling hand at parting, before recommencing my journey, he presented me with a couple more feels of grain, which, without doubt, materially assisted my four-footed friends in rapidly traversing the balance of the debatable ground. 


\section{FISHING OFF THE CAPE OF GOOD HOPE.}

Wro has tried the fishing in Simon's Bay, Cape of Good Hope? Well, I have, and had such a take of fish as seldom do I remember falling to my lot. Those who have not visited southern Africa will please to learn that the coast is wild, irregular, and rocky; possibly as uninviting as can be imagined; and the waves that roll in on this distant shore, are giants in stature. Outside the anchorage of Simon's Bay is a light-ship; it marks the end of a most dangerons reef, which has pounded many a hole in stout-built vessels: but this reef, though repellant to navigators, is most attractive to the inlabitants of the briny deep; and close to the light-ship, on the edge of the reef, we dropped anchor and commenced work.

The bait, which certainly deserves a description, for such curions-looking shell-fish I never previonsly saw, was neither an oyster nor a mussel; it looked a little like both, for it had a hard external sheli, and 
numbers clung together in bunches; but oh, reader, hold your nostrils while they are opened, a description of the perfume is almost impracticable. If you have met a pretty little animal in the American forests, called a skunk, got a grood suiff of his otta not of roses, you may imagine the other, being tolerably similar, only that there was the additional flavor of decomposed fish. But if we disliked the perfume, and made wry faces over it, the fish did not. 'They took it with a bolt the moment it reached the bottom. The prizes that we obtained were all rock fish, some of them of immense size; in two or three hours we must have had several hundred-weight in our boat, but unfortunately it commenced to blow, and we were compelled to up anchor, and run for it. IVeather on this coast is very variable, not unlike what often will be experienced in the west of Scotland.

From the ship some of the seamen took a splendid fish, both for table and appearance. By the bumboat people it was denominated the Cape salmon. As might be supposer, it had no relationship to the salmon family, but belonged, I think, to the same genus as the striped bass of North America. The two are much alike, only the former is without the lateral lines possessed by the latter. This fish is well known 
here, and I believe is esteemed their best for the caisine. A wonderful place also is Agulhas Bank for fish, but you must be becalmed to enjoy it, no pleasant circumstance when you are either in a hurry home or the reverse. A calm away down in those ocean latitudes does not bespeak a level deck, no, quite the reverse, the ship heaves, pitches, and rolls with the long swell. All motions are combined in her action, and the yards, masts, etc., creak and groan in the most discordant complaining mamner. No, no, far sooner would I hear the blast whistling through the shrouds, ay, and so fiercely that the boatswain's whistle only played second fiddle, than listen to the complaining labors of a becalmed ship in the Sonthern Indian Ocean. But about Agulhas Bauk. A friend of mine, a really good and experienced fisherman, had the luck (if such it may be called) to have a couple of days' fishing on this distant shoal. Now this person had fished on the Newfondland. banks, and had wondrous tales to tell, but never anght like this. IIis belief is that there is not a place in the world to equal it as a fishing-gromud. If this be the ease, is it not surprising that some tight little schooners have not yet marle it their haunt? 'The weather here can not be more formiclable or dangerous 
FISHING OFF THE CAPE OF GOOD HOPE. 137 to shipping thian the northeast coast of America, while the traffic and consequent danger of collision is infinitely less; moreover, there are excellent markets within as accessible distances as the vessels have that sail annually from British and French ports for the great bank of Newfoundland or the Labrador coast. 


\section{A BEAR ADVENTURE.}

In following a flight of ruffed grouse, which had risen so far beyond range as to have prevented $\mathrm{my}$ getting a shot at them, I came across a perfeet brake of wild grape-vines loaded with fruit. I could not withstand the temptation of halting for a feed, for they had been touched by frost, which ehanges them from the most unpalatable to the most delightfully flavored fruit. The day had been warm for the end of autumn and I suppose the fatigue of my tramp, together with the delightful shade afforded, indueed me to lie down, and, as might be expected under the circumstances, I fell asleep. Iow long I might have been in a state of oblivion I can not say, but I was awoke by my companion, a mongrel English terrier, barking vociferously at some intruler. $\Lambda$ fter a stretch, a yawn, and the nsual awakening aetions, I turned in the direction of Prince to see what on earth had raised his ire and disturbed my siesta, when, judge my astonishment, I beheld a large bear erect, pull- 
ing down the vines not twenty yards off, ignorant of my presence, but occasionally casting a furtive glance back at his angry assailant, who took precious good care to keep beyond arm's length. Iren become cool in such situations, either from association or the power of controling their feelings. My gin lay at my side loaded with number six; if Bruin found me out and beeame aggressive, at close quarters, say eight or ten yards, I was prepared to risk the issue; if he would only move off a little way, still keeping to windward I thought I might improve my opportunity by substituting a brace of bullets. Under any circumstance my gun would be required, so watching the first opportunity when the bear's back was turned, I brought my double-barrel close by my side and cocked each lock. Many may laugh when I say I did not feel nervous, but I did not, and remained watehing with special pleasure the enjoyment that my foe appeared to take in crunching up whole bunches of the lnscious fruit. As he worked farther from me my dog became less demonstrative, only occasionally giving way to a suppressed growl, which his feelings were unable to control.

First one barrel was unloaded and the heavier missile substituted, then the next underwent the same operation, Bruin being now out of sight, still within 
hearing; but the tables were turned; if formerly I was prepared to leave him alone, I now felt equal to acting on the aggressive. Giving Prince a little encouragement, he again rushed to the attack, and it is wonderful with how much more ardor, knowing that his master's eye was on him. Soon I knew the dog had nipped him, for I heard a rush, and dogs will retreat toward their inasters, which brought Bruin full in view. As the distance was greater than I liked, I hesitated to fire, but the bear had seen me, and disliking my appearance, turned to make off', but the brave little cur was at his heels, and as I cheered him to the attack, he never lost an opportunity of pinching Bruin's stern, who at length tree'd to avoid the persecuting little pest which hung on his rear, the most desirable course for me he could have adopted. By the time I reached the spot the enemy had gained the first fork, not twenty feet overhead, and is it to be wondered at, that at such a short range, with not a twig to intervene, and with a clear view of his shoulder, one barrel brought him to the ground with no more life in his carcass than the usual death-struggle? My trophy was not large but well fed, and his hams afforded me for many a subsequent morning a bonne bouche worthy of a hunter. 
But poor little Prince got into trouble before he reached home. As I struck the margin of a river which lay in my route, I observed a large bald-headed eagle sailing about. Keeping under the shelter of some brush I waited for a chance. My right-hand barrel I had reloaded with heary shot, and, as the bird passed about seventy yards off', I gave him a portion of its contents, which was responded to by his immediately reaching the ground with a broken wing. Prince, plucky with the issue of his late engagement, made a dash at the bird, but caught a Tartar, for he was seized by both talons, and, but that I came to the rescue, would have been rendered useless for any other purpose than baiting a wolf trap. As it was, after I had killed the bird I had some difficulty in loosening his claws, and I doubt if my faithful little mongrel had lived to the age of Methuselah, he ever would have been induced to tackle another eagle. 


\section{FISIING IN MAINE-CHAR OR TROUT.}

Mune, one of the oldest States of the many that compose the Union, is, strange to say, less densely settled, less cultirated, and probably less known, than many of those that can date their existence no further back than ten or twelve years. The canses to which this is attributable are three, viz., the severity of the winters, the indifference of the soil, and the rugged mountainous rocky surface of the landscape. But where man is searce, there look for the wild denizens of the forest. Ifere the moose, caribon, and bear are still to be found, the homes of the beaver, otter, fisher, and mink remain undisturbed, and even the dreaded panther, painter, or more correctly, puma, is not rare. Neither are fish wanting; the country is a perfect laloyrinth of lakes and rivers, which swarm with various species of the salmon genus: but sidd to say, the grand, the grreat, Sulmon 
salar, the beloved of the angler, the bonne bouche of the epieure, has almost disappeared, for unfortunately, on all the outlets of the rivers, there are towns, and the inhabitants have long since verified the proverb of the goose and the golden egg. What Englishmen have done at home, so have their cousins done across the Atlantic. Englishmen and Americans, as merchants and traders, have been credited with acumen and foresight; such eredit they may have justly earned abroad; but their policy in reference to their home fisheries has been totally the reverse. Let us hope that they will at length see the error of their ways, and unanimously adopt the means that scientific men have pointed out, for remedying and counteracting their past transgressions.

But let not the enthusiast run away with the idea that in Maine there are no drawbacks to pleasure, that sport is found without an alloy, for the pests of every new land here swarm, black-flies, mosquitoes, and sand-flies; but fortunately their reign of terror does not exist over six weeks. The first (the blackfly), which is about the size of a small house-fly, and not dissimilar in appearance, is a perfect cannibal, refusing to be driven away, willingly immolating himself in his thirst for bloud, and drawing blood when- 
erer he ean obtain a footing, up your trousers, down your shirt sleeves or collar, everywhere he will get at his victim. Kill them by thousands, the phalanxes apparently undiminished will return to the attack; and even domestic animals do not eseape. The unfortunate cow that had been driven up to supply us with milk, I have seen changed from a strawberry to a black, by the myriads of these rampires that clung to her; and, but that we lit a large smudge* for her to stand over, I believe the poor old creature would have died under the incessant torture and irritation. But if the poor cow suffered, so did we, and it was only by constantly lubricating the exposed parts of our persons with oil of tar, or oil of pennyroyal, that we were enabled to stand the ordeal. Fortunately, the black fly is hungry during daylight only; like a respectable citizen, he early goes to rest, and equally early recommences business.

Next come the mosquitoes; I have found the same gentry troublesome in the Mediterranean, bad on the Malay Peninsula, worse in the paddy fields of China, but all these lack the 'cuteness and insolence of their

* Decayed damp wood, which burns slowly and emits a great quantily of smoke. 
Yankee cousins. If your hand is bare for a moment a dozen will be on it; when up to your knees in a pool, and fast in a big fish, both hands consequently employed, your face and the back of your neck will begin to itch-to burn-as if scalding water had been poured over them. Nor were the sand-flies deserving of better character, for though so small that you can scarcely perceive them, their powers of annoyance are tremendous.* Thank Providence that none of these wretches are made as big as the ferce naturce, or else genus homo must soon become extinct. I will here tell a little circumstance that befell the writer: he and two acquaintances were fishing under a fall; fish were abundant, but space, on account of the trees, too limited for so many rods, so down the stream he started, and forgot, in his desire to beat the other's in results, the odions preparation of oil of tar. After half an hour's scrambling through brush and climbing over rocks, he at length reached such a lovely pool. The first cast showed it to be alive with fish, and they in the proper way of thinking. Soon the gravel margin had over a dozen beauties glittering in all their glorious coloring, but the sun was near the horizon,

* Called by the Indians "No-see ums," from their minuteness. $7 *$ 
and the attendant warned the angler that time was up. On joining his friends, long and rociferous were their peals of laughter whenerer they looked at him. What the deuce was "p)? On arrival at the shanty all was explained. The black flies had attacked him when so immersed in his sport, that they had been unnoticed, or brushed off, making his countenance the most extraordinary-looking mess of blood and bruised Hies imaginable; but if he did not then feel the pain, you may bet he did that night when warm in bed.

Knowing that such torments exist, why did the writer go there? is naturally asked, and as simply answered, for before he started he was assured that not eren a mosquito was to be found in Maine. Afterward it was cliscovered that the visit of his informant had been paid to this Ultima Thule late in autumn. A dozen times conclusions were come to of sloping (not for Texas) in the morning; but the attractions were so great that the entire summer, eren on to the end of October, was got through, the last two or three months so delightfully, that the self-sacrifice endured in Jume and July was more than compensated for; and never can be forgotten the beantiful weather, glorious sport, and fice intepentent life enjoyed. The State of Maine being of considerably larger proportions 
than England and Scotland together, it is desirable that the particular locality should be mentioned. Seventy miles from the thriving sea-port of Portland, along the Grand Trunk line of railroad will be found on the map the picturesque, clean, flomrishing village of Bethel; twenty-seren miles north from it Lake Umbagog. Here you have the last settlement, and by following up the Androscoggin River, which enters the top of the last-mentioned lake, you get into a perfect labyrinth of lakes and ponds, mited together by brawling streams, only navigable by the lumberman's flat or Indian's birch-bark. On all sides precipitous momtains rise, covered with pine-trees where there is a possibility of their clinging, or immense bowlders, to all appearance ready to roll from their resting-place into the waters beneath. And here in this vast solitude, free from cares, we made our home, fishing or hunting by day, and sleeping such sleep upon piles of hemlock as seldom is enjoyed on feather beds (that is at the end of the fly season); for though the bears might growl around, the gray wolf give us a proof of his rocal powers, or the weird note of the loon come shrillyorer the waters, still all formed but a lullaby to make us rest the better.

In fishing the rivers of all the wild lands of the 
extreme northern portion of the United States and the Dominion for trout or salmon, little or no sport will be experienced by the angler until the snow-water has run off; in fact I do not believe the latter fish will enter a river that has not got rid of that addition. We got to our fishing-ground just at the desired time; a guide we consulted said we were too soon. It being better to be early than late, we pushed at once for our first halting-place, and the result was that we hit things so nicely that we struck the opening day. For about two or three weeks the take was very great, and the variety of coloring among our prizes something wonderful. A collecting naturalist, a pupil of the celebrated professor of natural history at Harvard College, Cambridge, Massachusetts, joined our party a few days after our arrival, and all these various colored fish were designated by him as Salmo fontinalis. To so great an authority I did not presume to differ, still when he informed me that the Salmo fontinalis of American waters was identical with our home brook-trout I thought that the lively, game little beauty of our mountain streams had wonderfully changed in color and appearance from his trans-Atlantic brother, or vice versê. As the weather began to get warner 
the more brilliant-colored specimens became scarcer, and ultimately ceased to be taken in the river. This circumstance induced me further to think that there was some difference either in habits or choice of haunts which their more plain clothed relatives did not affect, and that at least there were different varieties, if not species, among the inhabitants of this stream; and the more I think the subject over now the more thoroughly do I feel convinced that the name of Salmo fontinalis has been frequently applied to what is, in reality, our red-bellied char. Memory is often not to be depended upon, but with the assistance of a few notes (the lapse of time not being more than three years), I will endeavor to tell the differences that I most particularly observed. In outline of shape what I suppose to be the red-bellied char much resembled a well-fed trout, except that the first dorsal fin is nearer the head, the caudal fin has a wider spread at its termination, and the junction of their caudal fin with the body is more tapered away. In coloring the back was of a deep mackerel green, interwoven with irregular darker waving lines, while the belly was as brilliant as burnished copper. Above, where the green of the back and red of the stomach ran into each other, there were 
three lateral lines of large brilliant red spots, interspersed with minor straw-colored ones, and in some specimens the anal and pectoral fins had the first two or three spines black. Altogether in shape and coloring a more game-lnoking, beautiful fish can not be imagined; moreover, their table qualities surpassed in delicacy of flavor any fish I have evereaten, for the bright red flesh had a delicate nutty flavor indescribable, and, I fear, scarcely imaginable. Our guide, who was also cook and master of camp, used to fry in cream the smaller ones, and I doubt if ever prince or epicure had a dish placed before him more worthy of his palate.

But having given what I know to be, more particularly to the naturalist, a far from perfect description of this handsome fish's peculiarities, its habits, as differing from the tront I have known, may have interest. With the artificial fly they were not so readily taken as with mimnow or worm. When hooked I never knew them to spring from the water, and the quict reach of the pool was invariably a more certain find than the brawling neek. After sunset I never could suceeel in capturing them, and the best hours in the day were from sumrise till it commenced to get warm, and the two hours preceding sumset. 
After these fish had disappeared from the river, I discovered that they could be taken in the deep waters in the lakes, either with minnow or natural fly, the bait being sunk close to the bottom; and the places where I was generally most successful in this fishing was where, our guide affirmed, were situated the springs that partially fed these lakes; his reason for this statement being that this portion of the lake always remained open in winter, while the balance every year froze up.

Again, after these fish had deserted the river I had some admirable sport with them by going to the top of the lake and coming down on the amnial lumber raft. I was put up to this by the guide, he for years had followed lumbering, and the rafts as they floated down, he assured me, were always followed by swarms of trout. His information was correct as to the numbers of fish, but instead of the tront of the river, I found $\mathrm{my}$ beautiful-brilliant colored friend. This habit is peculiar, to say the least of it, and untrout-like, and I could only account for it in two ways, riz., either the shade afforded by these immense $\log$ s formed the attraction, or the constant immersion of the timber in the water caused the insect denizens of the bark to be drowned out of 
their retreats, and dropping off in the water furnished these fish with a favorite food.

Summer drifted past, and with it disappeared the incessant persecuting flies. Autumn, with all that brilliant coloring so remarkable in America, made its appearance, and the oppressive heat gave way to the most desirable temperature. An English antumn to me is always sad, an American autumn is quite the reverse; the hues and colors of the former are somber, in those of the latter brilliancy unsurpassable predominates. An American autumn once seen makes as lasting an impression on the memory of matureage, as the gorgeons fairy scene of the pantomime when first bebeld upon that of youth. For some time none of the bright-hued fish had been taken, and I much feared that my acquaintance with them for that year had terminated; but not so, a few sharp nights of frost took place, and going one morning to obtain sufficient fish for breakfast, in the run that formed the exit of the river from the lake, I with pleasure, in succession, captured several of the beauties. From that day forward they became more numerous, and the last morning's fishing which I here enjoyed, with the snow flying so thick that I could scarcely see my 
flies, I killed not only the greatest number, but the heaviest of the brilliant representatives I had captured during the season. With regret, having no desire to pass almost an aretic winter, I turned my back upon the three lonely, lovely lakes, with the following unpronounceable Indian names, Molleychunkeymunk, Mooseluckmaguntic, and Moligewalk, to scek the boundless prairies of the far West, and to substitute for constant companion, my double barrel, in place of my well-tried tapering fly-rod.

In my experience as a fisherman in Scotland and Ireland, I never knew of our river tront being eaptured in the sea. In Long Island, what is there called the brook trout (Salno fontinalis) is well known periodically, when practicable, to visit salt water; in fact they are constantly taken with the fly in the tidal portion of those streams. The char of Norway and Sweden does the same, and I can only say that both these fish are wondrously alike. On the other hand, the brilliant-colored inhabitants of the interior lakes of Naine, that I have mentioned, can not do so, for if they survired the descent of the Burling falls, their ascent would be impossible. Although the arctic char goes to the sea, the more resplendent colored relation remains, I think, con7* 
stantly in his fresh-water retreats-id est, supposing this is a char. To me it would be particularly interesting to know if my sumises as to the proper species of this beautiful fish are correct; and doubtless there are numbers of English fishermen whose verdict, even from my imperfect description, would set at rest a point important both to naturalist and sprortsman.*

* Since the above was written specimens have been forwardea to Mr. Frauk Buckland from America, and the surmises of the author are found to be correct. 


\section{A NIMAL LIFE. \\ "There is a pleasure in the pathless wood, There is a rapture on the lonely shore."}

Uxdoubtedly every one who loves nature has felt the truth of the above assertions, but is not this pleasure, this rapture increased by the addition of animal life, whether it be the occasional glimpse of the timid hare, the momentary glance of the graceful playful squirrel, the sea-birds dipping o'er the countless waves, or the fish-hawk hunting for his prey? Yes, there is society, where man does not intrude, and that society the most enchanting, that of the beautiful wild animals, rejoicing in their freedom, happy in their liberty, knowing no fear, dreading no intrusion. For hours in the far western forests of America I have stood, scarcely daring to breathe for fear I should disturb some family party, ay, although I knew full well that but for a successful shot, supperless I should have to sleep; yet who that could for a moment think, would wantonly destroy a mem- 
ber of the little coterie; disturb their innocent gambols, their playful, graceful tricks. Were they but for a moment aware of man's dreaded presence, all would precipitantly make a hurried and fearful retreat. The true lover of nature loves not alone the landscape, but loves those numerous additions, fascinating and inexpressible, without which, the effect of the grand foreground, the beautiful intermediate, and the soft subdued distance, would be materially diminished. In the northern portion of the State of Maine, the scenery is truly sublime; mountain after mountain rises, as if each strove to overtop the other. Giant pine-trees cling from precipice and erag, hanging as if suspended in the air, bowlders and rocks of all fantastic ontlines, far, far above threaten instant destruction to all underucath; brawling streams, grandly impetuous, leap and throw themselves from rock to rock, while every now and then glimpses of glassy surfaced lakes, embosomed in wood, form a lovely distance. But this country, lovely as it is, is almost destitute of animal life; no songster greeted my ear with his melody; no startled deer bounded across my path, so that an intense solitule that became painful prevented the enjoyment that might have bcen anticipated. But if grand natural scenery, ne'er des- 
ecrated by the hand of man, wants animal life to set it off to the greatest perfection, how much more do our tame artificial grounds and waters require this aljunct?

Few of our citizens can, when they choose, fly away into the highlands, the lake district, or the wilds of of Comnemara, but have to be satisfied with the artificial and formal beanties which our numerous public and private pleasure-grounds afford; but would not the enjoyment of those resorts be greatly enhanced if more animal life was added to the picture? In the city of Philadelphia a public park is tenanted by great numbers of squirrels, of different varieties, whose tameness, merry antics, and sprightliness canse them to be the admiration of all visitors. Could not squirrels be introduced here? not our common red variety, but the handsome black, gray. or ground squirrel of the American continent. What a suitable place would Kensington be for such inmates, and what a fund of amusement they would afford to the jureniles that in such numbers frequent it! There are also several beantiful varieties of water-fowl, whose advent would, I aun certain, be welcomed, such as the wood-duck, sprig-tail duck, loon, sheldrake, summer and black duck; all of these species are ex. 
ceedingly hardy, and the Serpentine and numerous other artificial waters are equally adapted to them. Further, while on the subject aquatic, I am informed that there are fish in the majority of these miniature lakes, but they must be of a very base order, grovelers in mud, so much afraid to show their ugly carcasses that the human eye is never greeted with their presence; of course in comparatively speaking stagnant water, the river or brook trout would not flourish, the lake trout might, although I doubt it, there being an insufticiency of depth without cool springs at the hottom to prevent the water in summer becoming heated, and a cold retreat is absolutely necessary for their health. However, there is a fish across the Atlantic, equal to either of the two mentioned, gamer for his size and a much bolder feeder, viz., the black bass, which is a frequenter of both rumning and still water, clear or muddy, an admirable table adjunct, and almost unmatchable in the eyes of the sportsman for pluck and gameness, taking indiscriminately the artificial fly or trolling bait, springing from the water when hooked, and refusing to be landed till after a long, fieree, and protracted struggle. I have killed a very great number of tront, and also black bass, and although it was a long time before 
I could believe that any thing of the size could equal the former, I have for some time been compelled unequirocally to give the palm to the latter. Now if we had this fish in the Serpentine, the water would not remain without a ripple; his presence would soon become known by his rising at the flies and otherwise disporting himself upon the surface. Who that has stood at sunset by the brink of some calm river, or the margin of some unrippled loch, say in the highlands, where trout are abundant, has not been delighted to watch the eager fish rising after their prey, and inwardly made notes of the size of each, from the amount of broken water displaced? When we have suitable homes to offer, do by all means let us have lots of animals; much room for thought is aftorded by their habits, much pleasure from their innocent pastimes, and the influcnce engendered by association with them is certainly most beneficial. 


\section{STRANGE FISHES.}

Wres returning from shooting pinnated grouse in the State of Illinois, I came upon a party of farmers who were netting a pond on the edge of the timber land. This sheet of water was about two-thirds of a mile long, with an arerage breadth of one handred aud fifty yards. The botton was composed of mud, except the southern end, where it was gravel. Only when very high floods occurred in the Wabash Rircr, was there outlet or inlet to this piece of water; still, I knew it was well stocked with fish, for on a previous evening, as I stood on its margin as the sun went down, waiting for wild duck, I had seen the surface in portions broken into spray with the fishes' numerous pastimes, or energetic pursuit of their prey. With curiosity I stopped to see the result of the first haul, and well was my patience rewarled, for what food for study was in the results! First and foremost, from the size and peculiarity of formation, I will mention what the fisherman designated a "spoonbill catfish" - a mame 
without doubt given by some one who knew as little about genus and species as a cow does about a watchpocket. This curious fish was beautifully shaped, with all those perfections that characterize the salmon family, but projecting from his head was a muscular continuation about sixteen inches long, and six broad in the center, not unlike the blade of a canoe-paddle. This spoonbill was entirely separated from and projecting over and independent of the mouth, the lower jaw being in its ordinary place; nor was the mouth large. As nature forms nothing without purpose, of what use was this projection? My own idea is that it was a feeler, used in poking about through the weeds, decayed vegetation, and mud : and by its sensitiveness the fish was enabled to find his food. On handling this rara piscis, I found that the slightest pressure on this attachment appeared to produce intense pain. The skin was entirely free from scales from the tail to the termination of the projection, and was very smooth and soft, not at all dissimilar to that of an eel. For a trifle I secured the prize, as I was assured he was an excellent table addition, and my informants were perfectly correct. I afterward cut ul the proboscis to satisfy my curiosity, and found it entirely composed of gristle, the surface underneath 
the skin being a labyrinth of veins. Afterward I saw, at different times, many of this curious family, thus proving what they are in no way rare; still, I have never seen them mentioned by naturalists. I'robably it is exclusively confined to inland American waters. Further, I would say, the vitality was remarkable, for after transporting it home it lived for over an hour. The weight of the entire fish was probably about sixteen pounds. The next attraction noticed was what is familiarly known in that ricinity as "the pond fish." In color it much resembles the beautiful black bass, in shape slender but graceful; the placement of the fins is the same as in the pike family, but the head is small and not unlike that of a trout. It is a greedy feeder, and from its being uneatable (the flesh being hard and rank) is considered a great bore by the fishermen. Their arerage weight is firom two to four pounds. Still another variety with which I had been previonsly macyuainted was taken, viz., "the great western cap" there called "the buffillo fish." It is frequently captured of enormons size-sereral I have seen over twenty poumls. They are much and deservedly esteemed, and are taken in immense numbers in the spring of the year by spearing; for as soon as a flood takes place, when the 
water is rising, they rush out over all the inundated lands, wherever there is sufficient depth for them to swim. For more than an hour one day I watched a lal, spear in hand, who had taken his post over an opening which passed under the Ohio and Mississippi Riailroad, made similar to a sluice for the purpose of preventing the water in time of floods becoming dammed. During my stay this youngster must have kiled a couple of hundred-weight. You must not imagine that these were all that were in the net. Sunfish, pike, pickerel, black bass, catfish, mullet, and turtle to a wagon-load rewarded the fishermen's efforts. In the end of the bag, I was about to place my hand upon what I consillered a rare prize, when I was stopped by the rough intervention of one of the people, and the exclamation of, "You don't want to die before your time? If he bite you, all the whisky in the gounty won't sare you." (Whisky is considered an infallible cure for snake bites.) This nondescript to be aroided was like Siebold's salamander, with four of the smallest and most awkward-looking legs; the brute was about fourteen inches long, and was there known as a water-dog. It frequently takes the fisherman's bait, who prefers to cut his line and lose the hook to becoming on any more intimate terms. 


\section{BUCK-SHOT.}

For many a day I puzzled myself to account for the uncertainty of the patterns frequently made with buck-shot, from the same barrels, with the same quality and quantity of powder; at one discharge at long range, say eighty yards, every pellet would enter a disk of five feet in diameter; at the next discharge, for no obvious reason that I could learn, they would be scattered over the extent of a coach-house door; through the first pattern it would be impossible for a deer to pass scatheless; through the second the probabilities were all in his favor.

However, after much time, I think not wasted, I believe I have hit on a method by which the wandering inclinations of buck-shot can be curtailed and reduced to considerable subșervience. For instance, we will suppose a ten-bore gun (the size I invarialbly used abroad) be taken; procure buck-shot of such a size that the barrel will exactly chamber four, that is, that four will fit in the barrel without using force. 
for if force be used their regularity of shape will be injured, and their flight will become erratic. Having thus learned the desired size of shot, make a cartridge of tolerably thick paper, carefully place your shot in layers of four each; with some grease reduced to a liquid consistency from heat, fill up the racancies between each layer, and as the grease cools and becomes solid, place in each layer, till the cartrilge contains sixteen pellets, when finish your cartrikge by inserting a thin, hard wad, turn down the surplus paper over it, and fix with a drop of glue. Since adopting the above method, I have frequently killed wild duck returning of an evening from deer shooting, at ranges far beyond the reach of ordinary drop-shot; at the same time I would not wish a sportsman to imagine that I would purposely load with this cartridge for duck shooting; but that I made use of them, as my gun happened at the time to be thus loarled. I am no advocate for long barrels, twenty-six inches being the length of the hardest-shooting shotguns, for ordinary shot, I have known. But I have observed that long barrels invariably throw back-shot the best; possibly the reason is that the missiles are then the less inclined to scatter, or that the friction with such large grain being less, the impetus does 
not meet the resistance presented by the smaller and more compact fitting grains. An American gentleman who for some months frequently shot with me, had a ten-bore gun thirty-six inches in the barrels, marle, I think, by a gummaker named Abbey, of Chicago, and weighing very nearly nine pounds. Such a camnon would soon have worn me ont, but my friend was big all orer and strong as an ox, and on the longest and hardest days, whether shooting snipe, duck, pimnated grouse, or deer, never appeared to suffer from its weight. Well this gun was an extraortinary performer with buck-shot; on one occasion I saw him kill a brace of deer right and left so far off that I hesitate to say the distance, knowing how slieptical many are on the subject of long shots. 


\section{THE AMERICAN TROTTING HORSE-IIIS ORIGIN.}

Triere is no nation on the face of the earth so thoronghly embued with a love of the genus Equus as we are; and knowing this to be the ease, I trust I may be parloned in advancing a theory which I believe not to be a fallacy, in reference to the origin of the American trotting-horse, and from what sonrce they inherit that specialty, entitling them to be aeknowledged the fastest animals in the world in that peculiar pace. But in case some readers are inclined to dis:llow this superiority, and dispute the point, that American horses are faster trotters than ours, permit me to state that across the Atlantic I have seen many nags that could perform their mile in harness in less than two minutes and a half, and three that have trotted the same distance in less than two minutes and twenty seconds; moreorer they have the most enduring qualities, as can be attesterl by several having performed their twenty miles within 
the hour; and that, after much investigation, I have been unable to find a single instance recorded of any thing like similiar rates of speed having been made by any of our home-bred animals. However, it would be better to state before going further, that there are plenty of thorough-bred horses in America; but it must be remembered that they are all sprung from stock imported from this country, and that they are totally distiuct from the fumily of trotters, although of late years the appearance of the latter has been much improved by judicious erossing the two,-in fact, so much so, that some of the late crack trotters have quite a racy look, one in particular, Lady Thorne, who, if her appearance does not speak falsely, would make no contemptible figure on the turf or across country; yet from all my experience and inquiries I have been unable to hear of a trotting dêbutante of pure breeding, nor do I believe such exists.

Some Americans I have heard avow that it was the result of training, and that Englishmen did not understand the art of teaching a horse how to make such use of his legs, so as to obtain the greatest amount of trotting speed ; and that they felt confident, that hat they but the opportunity, they could select out of our pastures numerous youngsters, who, in comsc 
of time, would be made successfully to rival the performances of any of the prodigies who annually exhibit on the various trotting courses in the United States. To this supposition I beg to disagree, for I am convinced if such rara aves existed, their excellence would as certainly be developed in an English breaker's hands, as under the tutelage of a representative of any other nationality. At the same time it is true that trotting is not paid so much attention to, or nearly so popular among us, as upon the Western Continent, where it may almost be designated the national amusement; but what person of means here would not be desirous of possessing a horse that could outpace all others on the roal, assist him to catch a train or post, transport him in the shortest time to distant meets, bring him home at railway speed after a hard day's shooting, or when thoroughly drenched, tired, and exhausted, with a long day's hunting in a heary country, land him at his hall door in half the accustomed time? Doubtless all would like such a useful hack, and doubtless such an animal would sell at a fabulous price; hence the inducement, if we had the raw material, to bring it to perfection.

But have we the material? I say not, but believe our horses and the American (not alluding to 
the thorough-hred, who are much in the minority in numbers) owe their origin to different sourees, that trotting is a national characteristic of the one, galloping or cantering of the other, ant the more I have seen of the two races the more thoroughly am I convincer that such is the case. In Kentucky, when visiting the farm of an extensive breeder, and who has bred and owned some of the most eclebraterl race and trotting horses in that State, I inspected both his droves of young ones, the race-horses and the trotters (for both families are kept separate and distinct), and was very much struck with the marked difierence in their appearance; the latter being heavy chesterl, large limber, small headed with tapering muzzle, while the tail was generally set on very low. IIowerer, if they differed in appearance, in manner and habit they were more essentially unlike: when you alarmed the thorough-breds, oft they went at a swinging gallop; if the trotters, their farorite : pace would be chosen, and in few instances, however much you might coerce them to increase their speed, could they be induced to break, and it must be borne in mind that the majority had not yet paseed into the breaker's hands, so that their action was natual. 
Again, I purchased a horse in Illinois, the produce of a very good trotting-mare. $U_{p}$ to the date of my owning him he had never been in harness. After a few trials he showed a very great turn of speed, and in a.month or two was a rery fast trotter; and so much did he prefer this gait, that no amount of punishment would cause him to break. Now, in this animal's edncation I did not use other means than those I have always practiced at home; still, I never previously had a hack that could drag a conveyance at the same relocity. To whom was the credit due, the hor'se or driver? Doubtless the reader will agree with me.

In temper and disposition a great discimilarity is also apparent, for, as a rule, the American horse is very free from vice (kicking and biting being rarely found), slnggish, patient, and subservient, not unfrequently without a certain amount of mulishness in look and mamner; in fact, one of the most celebrated trotting stallions (the sire of Dexter, who has made the best time in lamess on record, and many others almost as good), is the most wonderful likeness to that useful cross, viz, between the horse and ass, and thoroughly dissimilar to any of his race that I have secn in England; however, he must not be talien as 
a representative of all, for few handsomer harnesshorses can be found than Patchen, Jun., Butler, and George Wrilkes, all three of whom have reaped honors which will long render their names famous among the patrons of the American trotting turf.

IIaving stated my belief that the transatlantic trotter has a different origin from our home stock, it behooves me now to endearor to point out the source from whence he came, and thus in part account for the marked difference which characterizes him. The borse is not a native of America. If we may believe historians, on the discorery of the American Continent, no such animal existed there; the distant prairies and western slopes, which are now traversed by immumerable droves of wild horses, were then entirely without this grenus. But whence are they sprung? How are these innumerable herds which are now found there to be accounted for? In the following manner:-The Spaniards were the first people to attempt any important conquests on the American Continent. The first horses that were landed in that country were the chargers of the military force under the command of Cortez. The matives who at first received the foreign invaders with the strongest demonstratiuns of weleome were 
overwhelmed with wonder, and awe-stricken when they beheld the strangers mounted on animals dissimilar to any they had previously seen. Nor were the Spaniards slow to arail themselves of this artvantage, and in the numerous re-enforcements constantly forwarded, cavalry formed a large portion; familiarity between the natives and the dreaded animals soon reduced their fears, and as a natural consequence in many of the engagements that took place, the rider being slain the charger was cast upon his own resources and became free. Again, upon the line of march, doubtless many a foot-sore and exhausted animal was left to perish, but liberty and rest imbued him with fresh spirit, and the forsaken, broken-down steed, with abundant pasture, abundant water, perfect idleness, and self-control, soon became thoroughly resuscitated. Further, we learn that on one of the repulses which the Spaniards were subjected to, in their hurry to save their lives, they turned their horses loose, and took to their ship; and still again, when De Soto discovered the npper" waters of the Mississippi, he tumed all the expedition's horses free, as he had determined to continue his researehes through that then terra incognita, on the bosom of the mighty father of waters. From 
these horses introduced by the Spaniards, introduced by De Soto, are doubtless sprung the countless teams that the traveler may daily see orer the unperoled plains of northern Texas and northern Mexico. The Spaniards then bronght the first horses to America, from whence did they obtain them? None could be got nearer than Europe, none more conveniently than in their own comntry; we have, therefore, every right to conclude that the horses were from Spain, probably from the sonthern portion of it, as horses are more numerous there, and the inhabitants more partial to hor'semanship. Who, that has trav. eled in spain, if his eyes have been employed to take observation of more than the sierras and señoritas, can have failed to observe that the native horse is very unlike (in many respects) the English or French species, and that this dissimilarity increases the farther you go south; but it is in this very dissimilarity that the descendants across the Atlantic differ from our home breed. Moreorer, in Spain I have observed among their nags, a great deal of what is termed in America "knee-action," a peeuliar method of raising and placing the foot down, which is considered a necessary by the comnoissem in selecting an embryo trotter. The Spaniarts like this action, 
they think it showy, and cultivate it in their saddlehorses, but for the purpose of display, they being too indolent or ignorant to turn it to better account. Further, the roads are generally villainous throughout the land, and very unsuitable for quick driving, in fact some of the most wealthy and aristocratic Spaniards, even at the present day, always use mules in their carriages.

The Spanish horse doubtlessly has a very large proportion of Barb blood in his veins, more especially those of the southern portion; this may be accounted for by the shortness of the sea passage which ir the neighborhood of Gibraltar, in suitable weather, even before the days of steam, could be made in three or four hours; but the influx of Barbs into Spain, which must have been great, I do not attribute so much to accidental importation of individuals, as to the numbers which must doubtlessly have been taken there during the Moorish ascendency, for the purposes of war, more especially as the Moors at that period were famous as cavalry, and relied principally on this arm of the service for carrying out successfully their predatory system of warfare.

The Moorish horse also has very frequently this knee-action, previously mentioned in the spaniard. 
I was particularly struck with it in some colts in the neighborhood of Tangiers, and more especially in a horse, the property of one of the consuls. Qut of the numerous importations which come to Gibraltar, I have seen several who conld trot very well, and if pains had been taken, might have been made fast, not perhaps so fast as the American; but then it must be remembered that he (the latter) is a larger animal, of greater muscular development, which he loubtlessly owes to superior climate, intermixture of English blood, and the cultivating of this pace through successive generations.

In proof that the Barb can be made a trotter, it may not be irrelevant to mention that, when in Malta, I possessed a Tunisian horse as a hack. I ran him in one or two of the scratch races that frequently take place on the road to Sliema: however, he acquitted himself so badly that he, and I fear his owner, became quite a laughing-stock. Now, although this horse conld not gallop, he conld trot; and often surprised me with his spurts of speed when pushed. After mess one evening, a staff ofticer, who was my guest, kept chaffing me on what he was pleased to eall my dromedary. To put a termiuation to his nonsense, I offered to back myself to 
trot him to Sliema and back, from the St. Frances gate, in less than thirty-îve minutes. The performance was accomplished, and rery much under time; nor in the return did I push my nag, as I found I had the race in my hands. Now this Barb, if he had been in the possession of a person who would permit him no other gait, would doubtless have become a fast trotter.

Although a great many years may have passed since any direct importation of horses from Spain to America took place, still the resemblance between the two breeds remains most striking. The celebrated sire, known as Rydsich's Mamiltonian, whom I have alluded to hefore, as the father of the present champion of the transatlantic trotting turf, is mlike any horse Ihave ever seen in England, but is a perfect counterpart of many animals I hare seen in Spain and Moroceo, except that the American has the adrantage in height and substance. Few of us have not seen pictures of the celebrated horse, familiarly known as the Godolphin Arab. Now, this horse was doubtlessly a Barb, his appearance at once tells it, if we can place reliance on the correctness of his portraits; and eren conld we not, the majority of authorities who have written on hurse8* 
flesh, pronounce him to be so. In Anerica I showed a picture of this animal (if I remember correctly, (lrawn by Stubbs) to a well-known breeder and possessor of trotting stock, and he assured me that it was a most perfect portrait of the sire of several trotting celebrities, and very like many others he had seen.

I have further observed that a great number of American horses were addicted to those most ungainly modes of progression ealled racking and pacing, a gait that is very seldom seen in England, while in Spain and Norocco it is extremely common. In fact, the Spaniards highly approve of it, believing that it shows both horse and rider to the greatest perfection; nor is the American behind him in this taste, a good pacing hack being deemed by all as the most desirable animal for saddle purposes. IIaring shown, I think, conclusively, the similarity in appearance and proclivities between the American and the 13arlb, and further, how I account for the importation of the preponderance of Moorish blood in the Western Continent, I will encleavor to show the difference between the Barb and Arab, how our English stock, with few exceptions, takes after the latter, and that it is from this diflerence of parentage wo 
may attribute the superior speed in trotting of the American horse over our home-bred animals.

During an experience in the East that extended over three years, where I had the fortune to see every varicty of Arab; fiom the pure-bred Medjid to the Persian, I never knew one that was a good trotter or was gifted with knee-action; their paces are prineipally walking, galloping, and cantering, their morements being too close to the ground to excel in the trot. Nor can this be accounted for otherwise than from the great difference in the characteristics of the surface of the ground in Arabia and in Barbary, and that Nature with her wonderful forethought has adapted the gait of both races to the different surfaces over which they have to travel. If we are. correctly informed, the districts of Asia, where the pure caste Arab is reared, is undulating, very sandy, and sparsely covered with regetation; where the colt or mare can, without any fear of danger of interruption, lay well down to a gallop. But, on the other hand, Barbary is rough, rocky, and mountainous, intersected with ravines, and in many portions thickly corered with shrubs. On such grounds it would be impossible for a horse to gallop with safety, the velocity of his movements would certainly cause 
him to come to grief, and the better to aroid this he trots, his legs being all under him, enabling him to halt or turn to one side or cther with the greatest facility. Further, by raising his legs so high in this pace he saves his hoofs fiom coming in contact with stones and brush, at the same time giving him a better choice of where he will replace his feet. Adopting this action through numerous generations has dereloped those muscles which are more strongly brought into play, causing a change of shape; so that if the horses of Arabia and Barbary have a common origin, their difference of appearance can in some measure be accounted for.

So far I have been alluding to horses as trotters, that is to animals of such a height as would entitle them to that appellation. For a few moments I will take a glance at their more diminutive brethren, the ponies. Who in our metropolis has not been surprised to see how they trot, it may be under the weight of a patrician youngster or fat butcher-boy, in my lady's phaetorl, or a grocer's delivery-cart? Still they get over the ground at an amazing pace for such small quadrupeds, and much faster in proportion to their size and length of limb than their larger brethren. If we take up a sporting paper and see any trotting 
erents narrated or predicted, it is invariably ponies that are going to figure, and wonderfully good time the little ones make, exhibiting speerl, stontness, and endurance that is truly wonderfiul, But where do the most of our ponies come from? Devonshire, IVales, Shetland, Orkney Islands, Connemara, the wilds of Donegal and Antrim. Now on the coast of each place mentionel, portions of the Spanish Armala were wrecker ; a large force of carally doubtlessly formed a part of that fortunately ill-fated expedition, and is it not more than probable that many horses reached the shore? If so, these ponies have Spanish blood, and by that link are comnected with the Barb, their present diminutive size being the result of severe climate, exposure, scarcity of food, and possibly want of housing in winter. The wild horse of America has also become smaller than his ancestors, but not to so great an extent, from his range lying many degrees of latitude nearer the equator.

Further, all the above-mentioned places celebrated for ponies are rough, irregular, and rocky in their surface. Those who may be disinclined to acknowledge the Spanish origin or connection of our ponies may be disposed to think their trotting action is induced from the same reason that I attribute to the 
Barbs, viz., Nature adapting them to a pace which - is most suiter to the surface over which they have to travel.

Now this can not be said for the American horse; the gromul there is not stony and irregular, in those portions where wild horses principally abounded-the magnificent flat savamas or undulating praties on either side of the Mississippi; so that it may be safely inferred that trotting in the American horse has not been the adopting of a pace better suited to his present home, but the retaining of a peculiarity inherent in his ancestors. This is a further proof of the conneetion existing between the transatlantic horse and the Barb, also an additional inducement for us to believe that cur ponies have probably a large proportion of Spanish blood in their veins, and that from that source they obtain their excellence as tretters. I am aware that for some time great efforts have been made, more particularly at Exmoor, for the improvement of the original stamp of pony by the introduction of untersized Arab stallions. Suceess has been the result, and you frequently see ponies that are model race-horses, but, as a rule, the trotting proclivity does not exhibit itself in the beanties, lut in the rongh, shaggy, hardy, original breed, which not unfrequently 
more resemble mules, cart-horses, or even Newfoundlind dogs.

In Australia, where racing has long been the farorite amusement, and where great attention has been paid to breeding, the proof of which is the excellent time made on their courses, fairly rivaling the best we have on record, I never heard but of one nag that had gained a great reputation as a trotter. Now in this colony a great number of Americans reside, and they, doubtless to gratify their favorite taste if they could have found the material, would have had some steppers whose reputation would have reached the parent country. Now it is a well-known fact that the horse is not indigenous to Anstralia, but that it was introduced from England, Inclia, and the Capeall three so far from Barbary and Spain that it is extremely improbable that a native of the last-named countries ever set foot upon her soil. In Australia there have been no remarkable trotters. To Australia I doubt if there has been any direct importation of the Barb. Englishmen have long acknowledged the excellence of their through-breds to be attributed to the Arab cross; at the same time, it must not be forgotten that many Barbs have been imported of which, as I have previously stated, the celebrated sire, the 
mișamed Godolphin Arab was one; therefore a great many of our horses have Barb biool in their veins, but it is in the minority, the Arab being esteemed the favorite animal, and consequently moch more sought after when the foreign eross was deened advisable for the improvement of our stock.

In conversing with many Americang on the subject of their crack trotters, and in what sires and families they found this pace better developed, to the English stallions, Messenger and Mambrino, many years since imported into the United States, they gave the credit. Now if any one will take the trouble to hunt out their pedigrees, they will find a stronger cross of the Barb (going back as far as the Godolyluin and Barb mares) than is usually the case. Another stallion exported from bere into Boston (Mass.), and who a long time stood in Long Islank, near New York, called Bellfounder, or the Norfolk Trotter, has also produced a numerous progeny celebrated for this pace. Of his pedigree, although I nsed every endeavor, I conld learn nothing; however, a friend procured me a print, said to represent him when performing the feat of trotting $17 \frac{3}{4}$ miles in the hour, and never did I see a picture more remarkably represent an animal with the prominent Barb points. 
To the difference in disposition and temper between the American and the English horse to which I have alluded, much allowance must be made to the varied systems of breaking practiced. The former; as a rule, commence to handle their youngsters at a very early age, almost making them pets, till they become so familiarized with man, that when sufficiently old they go to work with the steadiness of old ones; while, on the other hand, the rice which we frequently see at home results from severity of treatment, or from the teasing of mischievous boys, or bad-tempered grooms, who are too frequently employed about our stables.

A statement of the time made by some of the most celebrated American trotters I will here appent, as it will doubtless be of interest to many; at the same time due allowance must be made that such is done from memory, I having unfortunately lost my records. Of one thing the reader may be certain, that if a mistake does occur it is only in the fractions of seconds. Flora Temple, one mile, on Kalamazoo course, Michigan, 2 min. $19 \frac{3}{4}$ secs. Dexter, at Buffialo, $\mathrm{N}$. Y., one mile in 2 min. 18 secs. Ethan Allen in double harness, trotting with a running mate, on Fashion course, L. I., one mile in 2 min. 15 secs., 
Dexter, his antagonist, being only two lengths behind at the finish, making his supposed time for the mile, 2 min. $16 \frac{1}{2}$ secs.

In conclusion I will state that I believe most thoroughly that the excellence of the American trottinghorse over ours is entirely owing to his having a preponderance or greater portion of Barb blood in his reins than our home-bred English animal, and for a proof that the American has this preponderance I refer you to his origin. 


\section{HINTS ON SIIOOTING.}

To lay down rules by the observance of which the majority of bad shots may become experts is easy enough; but the trouble is, however great the determination to follow the precepts may be, as soon as game is flushed the advice of instruction is thrown to the winds, and bang, bang, go both barrels, with the same unsuccessful results as previously. That more birds are missed by shooting too quickly, I assert as a fact that is indisputable; and knowing this to be the case, why will it continue to be practiced? For this reason, that many are so fearfully nervous that for the moment they have no control of their actions, or that they are so timid that firing off their gun they consider a duty, and the sooner it is got through with the better; neither of such pupils are ever likely to become crack shots. I have a friend who is, without exception, the most unlucky shotI was going to say the worst-that ever I met. We at one period very frequently shot together, and each 
evening, on our tramp home, he was certain to tell me that he had discovered the reason for his apparent want of skill. IIow various the causes attributed would be beyond possibility of enumeration; however, he always devised some means of counteracting them -viz., by stuffing cotton in his ears, not to hear the spring of the game; to wear a loose collar, so that he conld the better and more rapidly bring his head to the stock; to discard a waistcoat, for the thickness of cloth over his shonlder militated against bringing his gum rapidly up. However, he was always wounding birds-at least he said so; for constantly, if near, he would call out, "Don't you see the feathers fly?" which, perhaps owing to my less keenness of vision, I never perceived, sare it were the feathers flying off with the bird. Another peculiarity this gentleman possessed was, that although he might have discharged the entire contents of his shot-ponch without bagging a single head, as soon as we both shot orer the same point, one or other of the birds knocked down was due to his skill; donbtless companionship reassured him, or induced him to take more pains. I would alvise such, therefore, always to shoot in company, only I would rather be excused becoming the company. Of course oceasionally he would knock over a 
bird, but when this took place it either was lost or took no end of trouble to secure. I remember one instance in a marsh where we weresnipe-shooting, a number of mallards flushed within easy range ; following the report of his gun, one of the greenheads left his companions, sailed round several times, each cirele becoming lower and less contracted, till he dropped. Ialf-an-hour was finitlessly wasted in search, my friend would not give up, so I went forward alone; some time afterward he joined me, but lis perseverance harl not been rewarded. All that day he lamented orer this lost bird, for, like many of our fishing friends, he doubtlessly thought it (because it was not bagged) far larger and far finer than any obtained. The reason for the so frequent loss of the few birds he hit was this, the victim seldom received more than a stray grain outside the disk described by the shot, and therefore was not generally seriously wounded. That there are many like my friend I know, and I fear it will be a hopeless task to encleavor to make them good shots; at the same time I think there are many bal shots who might be much improvert.

I believe that too much importance can not be attached to the stocking of your giun. Occasional- 
ly you will meet with men who appear to do equal execution with either a crooked, straight, long, or short stock; but such's are rare, and when found you may feel certain that they have possessed unusual oj. portunities for constant practice. The length of man's arm, neck, and conformation of shoulder are so various, that seldom will a gun come up alike to different individuals; the straight, tall figure wants a crooked stock; the short, stout person, the reverse; and intermeliate figures, the bend between both extremes. I once possessed an excellent gun, with which I invariably acquitted myself creditably. The stock had always been an eye-sore, for it was composed of bad wood, and the previous owner had chipped and seratched it so bally that, after lengthened hesitation, I determined to have it re-stocked. However, when it reverted from the gummaker to my hands, I was surprised how indifierently I shot with it; but, on examination, I found that the new stock was much straighter than the old. Again: being in a neighborhood where game was abmulant, when I dicl not have one of my own gins with me, I borrowed from a frient, and my exceution was so bat that before the day was over I gave up in disgnst. This gum's stock was so straight that I doubt if any but its owner could lise it. In 
having a gun male, there is nothing that should receive firom the gunmaker more careful attention than the figure of the purchaser; for I feel confictent that a very great deal of bad shooting is male throngh want of attention to this point. Aggain : a gun should never possess a superfluous ounce of metal that is not necessary to its safety. When we start in the morning, fresh and rigorous, after a good night's rest, the weight may appear a trifle; but in the evening, if the day's work has been serere-more especially on grouse moor or snipe bog-yon will be surprised how little tells, and will induce you to undershoot your game.

Still another equally important point is the strength that is required to pull your trigger. After long practice you may get accustomed to either very fine or very heavy, bu whatever you are nsed to, that retain. With the tyro it is clifferent. Through frequent experiment he slould find out what weight of pressure he cangive without disconcerting his aim at the precise noment that he has obtained the firing line of sight. By imparting this knowledge to his gunsmith he will commence shooting under great alvantage. A great deal, we all know, depends upon a good start. It is almost equally applicuble to life, hurse-racing, and 
shooting. If you begin under advantageous circumstances success becomes probable. Success begets confidence, and with eonficlence we are certain to shoot well. An habitually bad shot has no confidence. Constant failure makes him doubt his abili$\mathrm{ty}$, his gum, in fact, every portion of his shooting paraplemalia. Nearly all persons who do not shoot regularly, fire their right barrel first. When such is the case, your left should shoot the strongest, as the second shot is so frequently at longer range. A good workman, however, will use either indifferently, and if such can be attained it should invariably be practiced, that one barrel may not be worn out sooner than the other. A fanlt which a great number are addicted to, is using too much shot. An ounce of number five, or any of the smaller sizes, is amply suflicient for a twelve-bore gun. However, if you have reason to use a larger grain, a quarter of an ounce more may be substituted. The reason for this is that the small packs the closer, and thus makes a more formidable resistance to the explosive power. For strong shooting, and, therefore, long shots, it is the driving force that is required, which you counteract by surplus lead, for friction is increased and fower wasted in starting the charge. 
Old hands may smile after reading the above, and justly say, "The fellow has told us nothing new ;" but remember we are not all old hands, and that all were once beginners, for whose benefit these hints are given. 


\section{A CIIINESE MODE OF FIS II I G.}

Is "Land and Water" is mentioned the circumstance, that while a pleasure party were descending the Thames, a large pike jumped on board their boat. The reason attributed is doubtless the correct one, but perhaps few of your readers are aware that in China it is a common practice to take fish in this way: viz., by inducing them to jump on board. I do not speak from hearsay, but have several times witnessed it, and will endeavor to explain how it is practiced. The boat used is built for the purpose, excessively long, narrow, of light draught, and close to the water. $\Lambda$ board abont three feet high and almost the length of the boat, painted snow white, is erected lengthways on one side or other, while on the reverse side from this board is attached to the gunwale of the boat, a shelf nearly the length of the boat, which gradually slopes to the water's edge also painted white. When the weather is calm and the moon 
bright, a single fisherman starts on the river in this craft, always shifting the board and ledge so that the former will be on the far sicle of the boat from the moon, while the latter is next it. The fish see the moonbeams glancing off this white arrangement and, why I can not say, jump at it, when they strike the board and fall into the bottom of the boat. On two occasions I examined the proceeds of John Chinaman's catch, and found it to be principally composed of gray mullet, and a representative of the Perka fami1y. The Chinese, to all appearance, are a most stupid-looking lot, still they are wonderfully cunning in circumventing fish and game; another instance of which is their training cormorants to assist them in taking fish. 


\section{AMERICAN RiUFFED GROUSE AND PARTRIDGE.}

W ITI but very few exceptions the grouse shooting for years has been an utter failure. Last year the results were the same, and we find ourselves thus early looking forward distrustfully to the future, hoping, but still doubting, that we shall ever again enjoy the sport which was usually awarded to our earlier experience. The grouse season for 1868 may virtually be said to have terminated, yet we are only commencing September, about three weeks' rery indifferent shooting being all the reward the sportsman has received in remuneration for keeping up a staff of keepers, a large kemnel, and, if not a proprietor, paying a heary rent for his moor, possibly not only for one but for several seasons past. This is a dreadful state of affairs, enough to discourage the most ardent, for although he has paid liberally, still no returns can be obtained at all alequate to the outlay. The journey to Scothand has been so much time thrown 
away, and the relaxation and pleasure well earned, possibly after tedious Parliamentary duties, supplanted by disgust, annoyance, and disappointınent.

From the heather let us look at the stubbles. Nearly all accounts taliy in the smaliness of the bags made and the extreme wildness of the birds. In this case we have not disease to lay the pancity of sport to, but a more than usually dry summer. Shooting in Fingland will thus be seen to be a very uncertain amusement, for if the birds should survive the numerous ailments of their infancy, our ecentric climate maly still intervene, and howerer good the early prospects were, when the time for enjoyment comes the spurtsman has to be satisfied, after hours of unsuccessful tramping, with the information that the heat or wet, or a combination of both, is the cause that so indifferent a bag is made.

If our game-birds are so susceptible of effects, that shooting becomes an amusement that can not be looked forward to with certainty, the best remedy to offer is the introduction of foreign game, hardy in constitution, suited to our country and the sportsman's wants. In time these strangers might be influenced by the disalvantages the home birds suffer from, but we would have variety, and the season that was unsuited 
to one species could scarecly be expected to be so to all. On the 12th of August, if the grouse fail, you lave no shooting. On the 1st of September, if the weather has been too dry and the heat more than nsually protracted, the partridges are so wild that indifferent sport can only be obtained. Now if the rufled grouse and American partridge were introdneed, if you could not fill your bags with one deseription you would with another, better far than returning empty-handed, disappointed, and probably out of temper.

The reasons that indnce me to select these American birds are that I believe they are in no way inferior to our own, that they are extremely hardy, withstanding with impunity the intense heat of the Southern States' summer, or the protracted winters of $\mathrm{New}$ England. Many I know have objected to them, becanse in the wildest portions of that continent, where man is seltom seen, when flushed they will oceasionally perch on trees, but this is not the ease in the settled parts, where they have become aequanted with dogs ant gums. In the Alleghany Momtains, New York, and Pennsylrania, I never remember such an incident taking place. Again, some assert that our country is too highly cultivated, which I deny, for 
the American partridge is only to be found in the neighborhood of furms; and I have been assured that this bird is more abunclant now on the western end of Long Island, which is close to the city of New York, and more carefully cultivated, than it was in days gone by, and the country more wild. The ruffed grouse, on the other hand, but requires irregular ground, plenty of water, and a fair proportion of timber, and they will attach themselves to a neighborhood without straggling off for parts unknown, like the pheasant.

That the ruffed grouse will breed here, there is scarcely room for doubt. I know that the American partridge has already done so, and that in a state of captivity; but let the experiment be made-the cost at most would be but trifling-and, if successful, their importation could be gone into on a larger scale.

In America, over a great portion of the country, their partridge goes by the name of quail. The same delusion appears to have crept over here, and a fear that the introduction of this species would be unsuccessful, for the reason that our migratory quail is scarcer now than in days gone by, from the land being more carefully tilled, is advanced as a caution to those who might entertain an idea of making the experiment. The 
quail of Europe I know well; I have killed them in immense numbers in Spain, Italy, and Greece. Twenty years ago in the north of Ireland, when partridge shooting, I seldom would conclude a day without bagging several couple; so I have no hesitation in saying that these birds are so totally dissimilar, that what might affect the residence of one should not be entertained as an argument to prevent the introduction of the other. 


\section{THE POIVER OF A SHARK'S $\mathrm{J} \perp \mathrm{W}$.}

EIGIIT bells had only struck a few minutes, and the old watch had been relieved, when the captain came on deck and ordered a man into the chains to heave the lead and obtain correct soundings. For several days this order had been so frequently given that it attracted little attention; and only that I happened to be lounging near the waist of the ship at the time, ruminating over a Nanilla cheroot, I should not have been an eyewitness to the following incident.

The weather was thick, blustering, and wet. For a day or two we had been unable to obtain an obserration, and as we were in a most dangerous part of the Chinese seas, it was necessary to be more than usually careful. Moreover, the barometer had suddenly fallen, a warning not to be neglected during the typhoon season; so our eautious old Scotch captain was not satisfied with bringing on deck the 
topgallant yards, placing the ship under reefed topsails, but had as further precautions the lead hove every half-hour. Although a long way off the const, the singing chant of the leadsman hitd in the earlier watches proclaimed six fathoms, six and a half: shoal water, all will say, for the center of a rast sea; but for days between the Straits of Sunda and the mouth of the Canton River you may sail without wetting the knots that mark ten fithoms.

It may be necessary to explain, for the benefit of the minitiater, that the deep-sea lead is a bar of that metal about two feet long gradually tapering from the base (which is abont four or fire inches in diameter) to the top, where the line is made fast. In the base is a deep inlentation, containing about half a pound of lard, which coming in contact with the bottom, informs the navigator (by the particles that adhere) of what formation the surface of mother earth is composed. The line which is attached is of various lengths (a hundred fathoms, I think, was on this occasion), carefully coiled in a tub, so that nothing can prevent it being freely paicl out.

Well, the lead was hove, aml rapidly the line ran out; five, six, seven fathoms were passed, still no stop, - - on, on, till double that number, yet no indi- 
cation of bottom. The captain looked surprised, but said nothing, till a third of the contents of the tub had gone over board, and then he uttered an exclamation very forcible, but far from polite. Howeser this did not alter matters, for soon scarce twenty fathoms were left. The seaman was now ordered to stop the line, and in doing so exclaimed, after a violent effort, that he was unable. Two or three turns round a belaying-pin soon settled this difficulty, and at length the lead was drawn on board. On being handled, it was found to be very much ent; so, to have a better inspection, it was transferred at once to the chart-room. On examination we found on the reverse sides a succession of furrows over half an inch deep, ont of which we picked, with the point of the compasses, a number of broken fragments of a large shark's teeth. The opinion of the majority was that the brute had smelt the fat and been thus induced to lay hold. From my knowledge of the habits of the fish, I believe he was attracted by the glitter of the metal passing rapidly through the water; under either cireumstance, the rapidity with which he must have dashed through the water to seize his prey, is a proof of the agility with which some of the species of this genus are possessed. The 
amount of strength of jaw necessary to make such deep indentations on a bar of lead four or five inches in diameter, can scarcely be conceived possible in a cartilaginous fish. If this shark is still alive, I pity the sailor that chances to fall orer board in his neighborhood. 
BLACK BAis AND MUSKALLONGE FISHING. 205

\section{BLACK BASS AND MUSK- ALLONGE FISHING.}

Is the memory of the past there are always reminiscences the recalling of which give us the greatest pleasure. Such is particularly the case with me when I think of the scenes and erents which I am about to endearor to describe. I was living on the confines of cirilization literally, for there was but one residence further north than the house of which I was an immate, and it was inhabited by a canny Scot, who never knew what it was to take a lay's relaxation, his entire energy, early and late, being deroted to the improvement of his homestead. Shortly after my arrival I paid him a visit, but I found that information on shooting matters would have to be obtained through my own exertions, for more than a complaint against Bruin occasionally depriving him of a pig, he knew literally nothing of the sporting capabilities of his neighborhood. It is always pleasant on a new field of operations to obtain a slight inkling of what you may expect. It is far fiom 
agreeable to have to draw a charge of snipe-shot, and thus lose time, to substitute $\mathrm{B} \mathrm{B}$, or perhaps ball, small game being expected and large game found. The locality of which I am abont to speak is at the extreme northern end of Lake Simcoe, where one uninterrupted forest extends northward for sereral humdred miles to the banks of the Upper Ottawa, except when an occasional lake or river occurs to break the monotony of this ocean of timber. In wandering about the neighborhood of ny temporary residence, about two miles from home I came upon one of those beantiful little sheets of water so frequently found upon the northern portion of the American continent. This soon became a favorite retreat, for wild inck were numerous on a portion where wild rice grew luxuriantly, and wood pigeons and spruce grouse had adopted it as a watering-place, owing to its freedom from intruders. All clevoted admirers of natme know what a pleasure it is to be alone where none of man's work mars the prospect, where every object the eye rests upon is as it came from the Creator's hands, musullied and unchanged. As I sat on a rocky promontory to see the sun dip the horizon, perhaps r isions of my dist an land and far-off friends flitting before me, I was struck with the immense numbers of fish that kept breaking 
BLACK BASS AND IIUSKALLONGE FISHING. 207

the unrippled surface,-good evidence that the rod and line might find abundant work, and on the next risit I determined to put it to the test.

To those who are acquainted with the birch-bark canoe it is needless for me to say any thing. All the praises I could sound could not further enhance it in their estimation; but to those who are not, to them let me say, that there is not in existence a more perfect piece of mechanism for the purpose it is intended. Only learn to handle it properly, and you can go in it anywhere, over shoals, down rapids, through channels where an-oar would be useless, and finally, if necessary, you can take it on your shoulders and tramp across portages where nothing but an ox-team could transport a boat. In construction they are models of skill, yet the Indian alone knows how to make them; for although a white man may occasionally attempt their manufacture, they never do so successfully. On the following day, with my birch-bark on my shoulders, looking like a gigantic animated letter T, I crossed the portage with a formidable array of lines and artificial baits, full of most mischievous intent toward the finny tribe. This day the surface was broken by that desirable ripple, 
whether it be for trolling or fly-fishing, and dark clouds occasionally darkened with their shadow the face of the water. With exhilarating freedom, deep I dipped my paddle, pushing for the rocky end, waiting till I had crossed the centre of the lake before I commenced to fish; for, as a rule, unless there should happen to be a reef, seldom any fish will be taken far from the margin. When alone in a canoe ore line will be found as much as can be conveniently attended to, for the navigation of your craft requires both hands. Getting under good headway, I soon had twenty-five to thirty yards of line astern, with a few inches of red eloth for lure, which proved so attractive that I almost immediately had a break, and in a moment or two afterward a fish hoked. Of all plucky, determined fish, to Black Bass I give the palm, they are so thoronghly reckless in their efforts to escape,-first springing from the water, then possibly coming at you like a cricketball, giving you often more than you can do to get the line out of their way,-next dashing to the right or left, and only succumbing when exhausted nature refuses to do more. For two or three hours such was the sport which continued with never over a few minutes' cessation. 
As I pushed slowly along the shore I came to a river previously unknown to me, and which I have since learned is the only outlet firom this lake. The edge of this stream was fringed with a dense network of weeds, and the channel had scarcely a perceptible current. On breaking full in riew several dozens of wild duck rose, conspicuous among whom were many of the beautiful wood duck, a gem among his brilliant-plumed race. What a pity at home we could not acclimatize this bird, but I fear his migratory habits would sally interfere. The sedgy nature of the shore here preclicterl pike, so, replacing the red cloth by a large Buell's spoon with some scarlet ibis feathers tied alung the shanks of the hooks, I again tried my fortune. Few who have not heard of the muskallonge, the king in stature of the pike family. He is to be found in nearly all the rivers and lakes of northern Canada. Among the shoals and rapids of "The Thousand Islands," on the St. Lawrence, he is said to attain an immense size, even eighty pounds; but the largest I have seen did not exceed two-thirds of that weight. Such large fish as the above I had not on that occasion to deal with, but before I ceased, the bottom of my canoe hal a goodly show of bass and pike: so many, that I was 
satisfied to select three or four for present use and hide the others, with my bireh-bark, till I could send across for them in the moming; but a couple of bears, judging from the different-sized tracks, got at my caclé during the night, and had the bad taste to maul and pull about what they did not eat, so that I rejected it as unfit for food. Fish I have always found the most tempting bait with which to attract Bruin into a trap, so I built a bower-house and hung up the bait at the end of it, with my trap nicely corered with leaves; still all would not do, he and his companion were too wide awake, or had left the neighborhood. This lake I often visited again, and with equal success; the influences of weather never appeared to affect the fishes' appetites, and they are always a welcome addition to a backwoolman's fare. In company of a Chippewa Indian I also tried fishing through the ice. The methorl adopted is simple, viz., cutting a hole two or three feet in diameter, over which is built a snall hut to keep ont the light and sufficiently large for the fisherman to sit inside, the end of his fish-spear protruding through the top. With an artificial minnow on a few feet of line in the left hant, and wrighted so as to make it rearlily sink, you attract the pike to the surface, when, with a 
BLACK BASS AND MUSKALLONGE FISHING. 211

dexterous blow, you drive your leister home. Very much like poaching; still where fish are so abundant and wanted for food, this system beeomes less culpable.

At the northern end of Lake Conchachin, the beautiful Severn, after tumbling over a grand fall, starts on its erratic, precipitous course for Lake IIuron. 'To visit this spot was not more than seren or eight miles of water, through a labyrinth of islands, and along the most picturesquely beantiful shore, wooded to the margin. Beside the fall was a sawmill belonging to a descendant of the French aristocracy, who had emigrated before the dass of "The Empire." Whether or not the proprietor happened to be at home, a cordial welcome could be relied upon, and the fishing underneath the fall was always excellent-sometimes so good that your bait would scarcely touch the water ere it was seized. However, there was one drawback, for the spot was infested with snakes, particularly a large, thick, dirty-brown water species, which logked exceedingly venomous. From the indifference with which the mill hands treated them, I imagine their look was worse than their bite. They had, however, a penchant for minnow, for I saw one captured on the 
hook. As the wild fowl migrate this is a splendid stand; for if the weather is in the least stormy, with an indication of cold, the ducks keep passing all day, and their flight invariably is so low that they are well within range. By following the Serern down to its junction with Lake Iuron, plenty of occupation can be found for both rod and gun; and the appetite your open-air life will impart will make all you eat taste superior to any thing obtained in civilized quarters. 


\section{LIFTING THE TRAPS.}

Ox the northwest of the State of Maine exists a ridge of hills which divide it from the tomship of Success, in the State of New IIampshire. Whatever may have been the cause (possibly the presumption of the namer), it has remained as wild and unsettled as it was in the days when the whole country belonged to the aborigrines. No, I make a mistake; a ruin of a tumble-down diminutive barn, on close scrutiny, may be found. The area of this township is composed of an immense meatow (through which a clear hut deep and sluggish stream flows) and the pine-clad slopes that divide it from the State of Maine. For some weeks I had been residing eight or ten miles distant from Success. The person in whose house I stayed was a trapper during winter, when the inhospitalle climate foiled any attempt at cultivating what at no season was a prorluctive soil. Night after night with pleasure I listened to his stories of how he had run down 
this moose, shot that caribou, or at length trapped the most troublesome of bears.

For some days my fly-rod had been indefatigably most successfully at work, furnishing not only my own table, but many of the neighboring families with trout, so that a change of programme was far from unaceptable. One morning as I was deliberating in which direction I would go, my host asked me if I should have any objection to accompany him to lift some traps he had not risited sinee spring. The trip promised an acquaintance with a new beat, and an insight into what I was not as yet conversant with in this section of the American continent, riz, the methor followed of trapping martens. As the sum was rising orer the eastern hills-for these primitive people are early risers-we found onrselves about to leave the surveyed road. My friend hore on his back a sack in which to place his longr-neglected traps, while I carried my trusty ten-bore double gum, loaded by request with ball in one barrel, and buck-shot in the other. Our route at first was through a dense cedar swany, excedingly irregular on the surface, while the mulerewth was so close that it was with difficulty parterl; a thick coating of moss was muler foot, so spongy and full of water that if we remained station- 
ary for a few seconds we would be over the insteps in water. Nevertheless, the tracks of the American hare were innumerable ; an animal, by the bye, which I believe very closely allied to the Scotch mountain hare, slightly changed by climate and different habits of life, caused by the very dissimilar localities in which they are found. A blazed path was all we had for direction, but as both were in the full vigor of manhood, we steadily progressed. Sereral times we flushed the Canadian willow grouse, but as my projectiles were not suited to this stamp of grame, and my companion continually kept informing me that larger might be looker for, I forbore troubling them.

From the swamp we got on drier soil, very rocky, and densely wooded with pine,-such glorious pinetrees as might one day form, withont discredit, the mainmast of a three-decker.

Upward, like the youth who shouted "Excelsior," we kept ascending, but we had not the maiden to warn us, but whose warning I doubt not, unless she had been unusually pretty, would have been disregarded. Soon the walking became climbing, and after an hour's clambering the summit of the ridge was reacheil. Here the first trap was lifted, and at intervals of two hundred yards or so, according to the nature of 
the ground, the others were found distributed. As they had been down for nearly two months, whatever had been captured was found in a decomposed state. Soon the whole had been gathered, over a dozen, when we descended to a stream literally alive with fish; trout of all sizes up to a pound, appeared to be actually crowding each other, while our presence by them was totally disregarded. Lunch-time had arrived, and on the margin of the brook we enjoyed our meal; several of the trout which my companion had taken with the most primitive tackle, and rod cut from the nearest tree, forming no inconsiderable portion of the meal.

After a smoke and half hour's dawdle, we started on our return, following an entircly different route, still equally disadvantageous for rapid progression. During our homeward tramp I learned that martens could only be taken on the highest ridges, and that the bait used was either a red squirel, the beautiful little eedar-bird, or the heart or liver of the Ameriean hare. I was not a little surprised at the number of times my companion halted to inquire if $m y$ gun was all right, more especially as so fir we had seen no indications of large game, excepting some broken-mp stumps, riloved logsis, or scratched trees where bruin long sinco 
had been searching for insects or stretching himself. As the sun set, we once more regained the path, well fatigued with our rough and protracted tramp, myself not a little disgusted that I had seen nothing sufticiently large to be worthy of considering fit game for the heary missiles which both my barrels contained; in fact, I could not help openly grumbling that I should have been inveigled into such a useless journey, to which I was informed that I might thank my stars we had got back safe. With this answer for the time I had to be satisfied, but that erening the mystery eame ont, and the selfish motives that had dictated my companionship being sought. I will endeavor to state the story as told by the trapper.

Last April, when the snow was on the ground, I laid out the traps we have to-day lifted. The traveling was rery bad at the time, for it was near the break-up of winter. I got along the ridge all right; but as I thought the walking would be better to return as I had come, I had determined to retrace my steps. I had scarcely turned about when I found to my surprise, the print of an animal following my old track. I lnoked in every direction to see where the follower could be, but was unable to detect him. However, I knew well that the skulking villain was 
no other than a painter (Anglice, puma); and as I had only my old single-barrel loaded with bird-shot, I became justly scared. All of a tremble, I started for home, and you may bet I made traeks. The very evidence of the brute following me, showed he was after 110 good, and I was right; for as I drew near the outside edge of the swamp, I saw him right ahead; but I went out of the way to avoid him, and after I left the rood I heard him howl, doubtìess in anger because he had missed having ne for supper:

At the time I could not help thinking that my host had been needlessly alarmed, and told him so, when he informed me that nothing would have inAnced him to return alone-in fact, that he would sooncr have lost his traps than do so; that a painter in those regions, more especially in winter, was much to be dreaded, and in corroboration informed me of a little tragedy that occurred some years past in the same neighborhood. 'Two friends once trappert the township of Success. They hat two beats, rmming in reverse directions, while the shanty in. which they hoth lived together was sitmated equally distant from each. The one who examined the traps to the north to-rlay, risited those to the sonth to-morrow, chamering their routes with each other daily, and always 
meeting at night at their common residence. Almost half the season had thus passed away, when the trapper who had returned for the night became seriously alarmed at the continued absence of his friend. At length the little cur dog who constantly accompanied the missing man came home alone. There is an end to every thing, and so there is to a long winter night; and with the earliest indications of day he sallied forth to find the missing trapper, whom he found dreadfully mangled and partially eaten. The assassin had been a painter. The tracks on the tell-tale snow spoke correctly. About thirty feet above where the corpse lay, an immense limb ran out at right angles from the parent tree. From this the skulking coward had doubtless sprung upon the unsuspecting trapper.

That the puma has attacked and killed human beings is weli corroborated; but fortunately he is such a cowardly, skulking scoundrel, that he seldom makes the attempt. 


\section{STRANGE FISII IN CALAI MAINE.}

Tue strange fish lately canght on the coast of the State of Maine, and dubbed the shark dog-fish by some of the learned in those regions, I have little doubt, from the description given in American periodicals is the basking-shark, for these reasons, that the basking-shark has been found on the Newfoundland banks not far from that neighborhood, that the basking-shark is the only proper fish with which we are acquainted that grows to this gigantic size, thirty-three feet long; that it could not belong to the whale family, or the inhabitants of that section of the coast, from their long experience and connection with the whale fisheries, would have known it, and given it either its proper name or a local one recognizable; and that from its being so excessively like an ordinary white or blue shark, with which the American coast abounds. To make the name more telling or characteristic it is christened with a Chris- 
tian name and surname, each of different species of the same genus. Don't langh at the Tankce misnomer; remember the tunny that was melted down into an albicore by some of our educated fellow-citizens and accepted natural historians. But still the most important part of the mystery remains unexplained. The anal fins of the basking-shark have an elongation of a different color and texture from the balance of these fins, which, if broken, would look excessively like a flipper on a small scale. If the carcass had been knoking about on the coast for some time before it was stranderl, is it not very possible that this fragile portion of the anal fins would get broken? and hence the fractured members in the imaginative minds of the country people, be supposer intended to perform the functions of feet. It has long been believed that the basking-shark lives principally on marine vegetable matter, although on dissection one was found to contain a portion of a mangled crab. In my opinion a desire for romancing or attaching mystery to a strange animal has indneed the good people of "away down East" to exaggerate the most strin ing peculiarities. 


\section{BUFFALO PLAINS.}

Wrrurs the last year or two the borders of Missouri and Kansas, where they adjoin, have become so much altered, from the springing $u p$ of ncw towns, and the making of the Atlantic and Pacific Railroad, that the points which were formerly considered the best starting-places for the plains, on account of their being situated on the verge of civilization, are deemed so no longer. IIowever, as in days gone by, I should choose Leavenworth for commencing outdoor life, if the intention were to reach the hunting ground by land. Although all frontier towns are to be aroided, from the number of loafers and blackguards that constantly haunt them, Leavenworth nowadays can scarcely be classed in this light; morever, the reliable and minute information with which you will be furnisherl by the ever-kindhearted oflicers of tho United States' regular army stationed in its fort, is most desirable to obtain. But instead of going by land, I would by choice take the river route by one 
of the numerous trading-boats that sail for the upper waters of the Missouri, every May, from St. Lonis. IIere, also, I woull purchase my horses and stores, which when once on board would be safe and well taken care of till required. However, to aroid the tedious journey up, the river to Leavenworth, I should leare my traps and nags (provided I had an attendant), and go by train to Leavenworth. Of course it would be even better, if your party be large enough, and do not object to expense, to charter a boat of your own, as you would then alivas have a comfortable home, good hard food for your horses, and the means of transporting many luxuries, which it would be impossible to carry with a limited number of pack mules, for the river is navigable through a large portion of the best hunting range, and from. the boats being of very light dranght you can land or ship your horses without trouble; on many occasions, while the vessel is progressing onwarl, you may be hunting, for the bends in the river are frequent and abrupt. The exact places where buffalo will be found is difficilt to say. In summer they keep going north, feeding on the just-spronted grass, up to almost the sixtieth degree of latitude, while in autumn their progress is south, till New Mexico and 
Texas is reached; nor do they follow the same rnutes yearly, the section of country passed over one season often being deserted for years. A few years ago the Black Hills used to be a favorite wintering-place of the hunter and game, but it was ever dangerons from hostile Inclians. All are now fled that locality, hunters, game, and Indians, and the formerly lonely sierras and woods now echo to the navries' whistle, the stroke of the chopper's ax, or the grunting of the locomotive; but why I mention the Black Hills is, that between them and the waters of the Yellow Stone and the Upper Missouri the sportsman can not fail to obtain more game than it is possible to makr. use of. 


\section{RENCOUNTER WITH A BEAR.}

In America a bear-story and a suake-story are synonymous, to the generality of listeners, to crammers. Knnowing such to be the case a man can not help approaching this subject withont nervons feelings, particularly when a bear figures as one of the principals among the dramatis personce of the narrative. But it matters not, travelers appear to be born to be doubted. I do not hesitate to say that they will sometimes romance, but invariably the fiction portion is credited and the reality ignored. We do not need to look at the experience of modern timss, our forefathers were impregnated with the same spirit; vide the reception poor Bruce received after his incredible hardships in Nubia and Abyssinia.

A friend, in the true sense of the word, and myself went to visit a small lake that was reported to swarm with trout, almost believing that no such place existed, but as a tramp through the woods was never objectionable we determined to make an effort to $10 *$ 
find it out. An old lumberman, long superannuated, gave us our instructions thus: "First go through the woods two miles north, then incline a little to the westward, and after about half-an-hour's walking through a swamp you will strike a small brook, which follow up and you will certain sure make the pond."** To those who have not wandered through an Ameriean forest, such instructions will be perceived to be far from lncid; to the thorough woodsman, however, it would be sufficient. Before we left the township road where we were to branch off, there stood ? shanty, at which we halted to put up the horse and buggy in which we had thus far traveled. From the head of the establishment we made inquiries, who, calling to his son, who was within, gave the following directions_- "Bub, take the gents and show them the pond." Now "Bub" was a most communicative youngster about fourteen years of age, and scenting a dollar in the distance, hopefully undertook the job. A cow-path we, the trio, followed for more than a mile, then we continued on what is fumiliarly designated a blaze road-icl est, a path marked out

* Small lakes in Maine are always called ponds.

† A Yankee father's farniliar way of addressing his son; daughters after the same manner are ealled "siss." 
by a tree at every hundred yards, more or less, having a piece scuoped out of its bark. The walking was as barl as possible, for constantly we were delayed by giants of the forest who had been prostrated by the gales of the preceding winters. At length, tired and frightfully worried by mosquitoes, we reached a brook eight or ten feet in diameter, but deep and sullen as a canal; down this we pursued an erratic course till between two lofty bluffs we came upon a beautiful sheet of water of an area of about forty acres. To fish it from the banks was impossible, for the sumac and cedar grew to its margin, so that no other resonrce was left but to cut a number of cedar logs and form a raft. An hour or more was lost in this operation, and when we had launched ont we found that nothing but the smallest fry could be taken, although these were in such quantities that frequently we would have three or four rises to a east. For an hour or more we fished indefatigably, still nothing over a quarter of a pound rewarded our labors, and when we landed for our pic-nic lunch I determined to fish the stream with the hope of obtaining some heavier specimens. My friend, who felt indisposed, either from the effects of the sun, or some State-of-Maine whisky (which is warranted to kill as 
far as a six-shooter), and which he had been imbibing, refusel to accompany me; so, with the youth who had acted as Palinurus, I left him to ruminate over his transgressions or misfortune.

As I had supposed, large fish were to be found in the stream, and my basket began to groan under its weight; when I hooked my flies in the top of a larch that leaned over the water close in my rear. With all my efforts I could not get them fiee, so sending the lad aloft, I waited patiently for him to cast them off The place where I stood was hummocky, such lumps as you come across in the bogs of Ireland when snipeshooting, only a great deal larger. Writh care and precaution the hummocks could be traversed without wetting a foot, but hurry would certainly get you between them, when over the boot-tops would be the consequence. I had stood for sereral minutes for the youngster to get the line loose, when across the stream, but a short distance off, I heard an animal grunt; the spot from whence the sound issued was a large clump of whortleberries, where some fallen timber lay. Not being quite certain that my cars had not deceiver me, I waited, when the noise was repeated. By this time my line was free, and my juvenile companion was descending, when I asked 
him to listen to the noise, for I felt convinced it emanated from no other than a bear feeding, enjoying his favorite bome bouche, the blue-berries. loung America listeneil; Bruin gave another grrunt of evident satisfaction, when the former-exclaiming "bear!" slid down the tree with such agility as would hare put in shade the majority of monkeys. As soon as he reachel the gromnd, off he started down stream, but the fumiest part of all was that my guide, in the precipitancy of his movements, must have tripped over the hummocks at least half-a-dozen times in a dozen strides. When we had got thirty or forty yards off,--for I followed, though searcely as rapidly,-my cmour propre asserted itself, and I halted; not so with my companion; soon he disappeared through the labyrinth of shrubs, and I remained alone. To my relief I found no bear was in pursuit, so, placing my rod against a stalwart hemlock, I ascended its branches to take a view of the situation; for a long time I could not discover Bruin, but at length detected a large mass of black fur, accompanied by two smaller ones, busily employed feeding. They had quitted the wet ground and were on the edge of an acclivity, where the mother was most industriously drawing the broken fragments of shattered logs on one side, while 
her hopeful progeny feasted upon the beetles and ants thus exposed. 'The old larly had neither winded nor heard us, and she remained sedulously pursuing her arocation, perfectly ignorant that her industry and strength were forming a subject of admiration to a son of Adam. At length their search for insects took them out of sight, and I descended to join my companious.

The day by this was far spent, and neither of us having arms suitable for an assault upon the happy fumily, we determined to seek the settlement and revisit the scene on the morrow. Next day, at an early hour, with quite a re-enforeement, all armed with most formidable fire-arms, from the Spencer rifle to the old smooth bore, and accompanied by a well-tried bear dog, we sallied forth; for miles we tracked Madam Bruin by the broken fragments of decayed timber and the numerous logs she had disturixed from their original resting-place.

Finally, we thought she conld not be far distant, and the dog was untied; off he went like a thunderbolt, and in a quarter of an hour we heard lim baying vociferously. Guns were looked to, the men most encrgetic previously now dropped behind, doubtless to examine their trusty rifles and see that the pow- 
der was up in the nipples; but when we reached Watch, what was our disgust, of course, to find that he had tree'd a covey of Canadian partridge? * Unwillingly we went to work and decimated this unhappy and unconscious brood, nor could all our efforts afterward indnce the unfailing bear-tog to take up the desired track; intensely disgusted we all returned, and bear-meat and bear-hunting for a long time were subjects that few of the would-be hunter's liked to hear mentioned by the residents of the settlement, for there was a strong suspicion that what was said on these subjects was said in chaff.

* Willow Grouse. 


\section{DEAS ON FLY-FISHING.}

To those who have gained skill from constant prac* tice in the gentle art, I do not address my remarks; still they can read if they will, provided they will do so in good temper, and furnish beginners with such minutia as have been forgotten, or have not been told. I faney I hear numbers discenting from my proviso, for it was only throngh long months, ay, years of toil-we may also say pleasure-they gained the information on fly-fishing which they now possess, and, therefore, why impart the result of their study to Tom, Dick, and Marry. But if our forefathers through generations had held back their views and experiences, for such selfish reasons, do yon suppose the machinist, the naturalist, the navigator, etc., etc., of the days in which we live, wonkl be as proficient as they are in their respective trades or sciences? For all Izaak Walton states, I much fear the followers of the rod and line possess the quality of selfishness. As one of its votaries, 
I can well remember keeping buried in my own bosom, the position of pools, the color of flies, etc., where I was either certain of taking the largest fish, or by the using of which, I could almost guarantre myself good sport. But I trust I no longer possess this love of self, and in no better way can I prove it than by endearoring to teach the young idea, not how to shoot, but to fish; come forward ye, also, who have experience, and help me in my task.

But to commence, we will first allude to the implements. The fly rod, like the gum, can not be too light, as long as it possesses the requisite strength. This is even a greater desideratum in the former than in the latter, for there is no convenient resting-position in which you can carry it incessantly; while on the river it is at work, not even the respite for loading being necessary, and if a heary gun after a hard day's work will make you undershoot your game, a heary rod will make you a sluggarl at evening in striking your fish, and the result will be about similar in both instances. For the trout fisherman, he, I mean, who fly-fishes burns and rivers, from twelve to thirteen feet is quite sufficient length for his rod to be (lake fishermen frequently use longer, but what they gain in reach they lose in quickness, a loss, in my estimation, 
of most serious importance), and such an implement should not exceed in weight eight or nime ounces. I can imagine I see many cast up their eyes and exclaim, that such is impossible to procure, but let me say they are mistaken. I have owned several of that weight, and with them, days in succession, taken baskets of tish, of not only all the ordinary sizes, but on one occasion I killed a trout nine pounds in weight. As I can not help regarding this as a performance to be proud of, I will relate how it took place. A comple of companions and myself were encamped on the margin of Mad River in Oxford Comn$\mathrm{t} y$, State of Maine. Our guns had failed to provile dinner, so taking a hazel wand I essayed to capture sufficient chub to make a chouder, a description of omnium gatherum stew. In taking a small fish, as I was about lifting him into the canoe a large trout rushed from underneath the birch-bark, seized the chub, and althongh I gave him both line and time to pouch what had not been intencled for a bait, on taking a pull upon him the chub came away, and I was free from the larger antagonist. Having taken suffieient small fiy I went home, brooling over my misfortune, but keeping the adventure closely locked in my own bosom (selfishuess again). About the hom 
that the sun began to dip behind the giant pines, I had made up my mind to the course I would pursue, which was to take my pet rod, mount a cast of two flies, and carefully whip the hole from end to end. As if it were but yesterday, I remember distinctly the flies. The trail one was ginger-colored cock's hackle, with light corn crake wing, tipped with silver; the dropper a large-sized moth.

"For" work at that hour," I hear some internally mutter, "the moth did the business." No, it did not; cock's hackles of all shades may invariably be backed against the field, and the cock's hackle on this oceasion kept up its reputation. Down on my knees in the bow of the canoe, the camp-keeper holding her hack by a pole in the stern, slowly and cautiously I fished the throat, from thence down into the less angry but wider-spread current, when just as my flies passed over an eddy that divided the downward flow from the back water, there was a splash rapidly responded to by a nervous quick movement of the wrist, which planted the hook firmly home. I doubt if I exaggerate, in fact I think I scarcely state enough, when I say that thirty minutes elapsed before my trophy could sufficiently endure the sight of a landing-net to have it placed under him. Thus 
was taken the largest river (salmo fario) trout I ever canght. But to my rod; it was made out of cedar from butt to tip, did not exceed nine ounces, and was the most lively, quick, light casting treasure I ever used. Cedar fly-rods I have heard objected to, because they are brittle; doubtless you may find them so, and your casting-line also, if you change its use into that of a carriage whip. Howerer much I admire a cedar rod I do not think it suited for a tyro, but when the beginner has gained experience, and is able to offer an opmion and "use a fly rod as it should be used, I doubt not he will perfectly agree with me. A cedar rod ean seldom be purchased ready made, as tradesmen dislike the job; so if any readers of "Gmn, Rod, and Saldle" should wish to possess one, he had better go to the very best workman he knows of, and give him the order.

Next to the cedar rod, hut one that will stand any anount of fair work, is the split bamboo; this, I think, can be procured oren lighter than the former. There is a firm, the Messrs. Clark, of Maiden Iane, New York, who make this a spécialité. I never had the fortune to use one, but have handled them often and listened to the raptures of experts on their merits; on their good qualities I believe I can say nothing 
that they do not deserre, but their price is necessarily high, from the care with which the cane has to be selected and put together.

When I was a boy, I beliered Flint and Martin Kelly, both of Dublin, before all other makers. I have used their rods over a great portion of Englant, Scotland, and Ireland, and did not, until I used the cedar rod, believe that any rod ever was made that could compete with theirs, but so it is, and so it will continue to be. Old bluff-bowed lumbering packetships sufficed our fathers to go to India; now we have the $P$. and $O$. service, with rail across the Isthmus, and it is far from probable that this means of transit will always suit our children. If Joe Manton was to arise among us, I doubt much if he could hold his own among moder'n gummakers.

Some persons, particularly Irish fishermen, are attached to double-action rods; that is, rods which have so much elasticity in them, that they display two movements, one up and the other down, when suddenly used. I do not like them, for more than one reason; the movement of the wrist in striking the fish, while raising the butt, throws the tip down, thus giving quite a contrary motion to what is intenderl. Agran, if you have to fish against the wind, they 
will not only be found most difficult to manage, but excessively fatigning. There is a rod made in Castle Commell (principally for salmon), after the above pattern; it has many admirers, who donbtless through experience have become proficient in its use; still I can speak only from what I know, and my verdict is, leare them to their present arlvocates.

A combination-rorl has always been my horror. I mean such as fishing-tackle shop proprictors guarantee to be both a perfect fly and bait rod only by altering the tip. If persons will but use their brains they can in a moment see that snch is impossible. The two uses are essentially different, recuiring the spring and elasticity in totally different parts. The act of placing a dull, lumbering tip on the first three joints of a delicate, pliant tront rod is really desecration. ITowever, some may say, you will find a medium between the two more generally useful. My answer is, what is worth doing is worth doing well; and if your intent is fly-fishing, the most perfect rod for that purpose should be selected. If the river is so discolored or swollen that bait has to be resorted to, or you must go supperless to bed, for gooduress' salke go amb colt a hazel waml, muless you cary a bait rorl-an ant icle for capturing trout that no true fisherman ought to 
be proud of. In fact, I am not certain that its possession should not entitle the owner to be arrested, in the same way as a pocketful of snares for game would a known poacher. IIybrids, whether in rod or gum, are to be carefully avoided. I remember being once entrapped into using a hybrid gun, in the township of Markham, Upper Canada. Going through some brush I flushed a quantity of woodcock. I stated the circumstance when I returned to the farmhouse where I was residing. As I had no gun with me the host offered me the use of his, which from his description was wortly of a royal duke and therefore I accepted the offer. On production it proved to be half shot-gun, half rifle- that is, the right-hand barrel was smooth, the left rifled. This was my first experience of such a weapon, and most probably my last. The game was found, the cover was close, and snap shooting necessary. It was of no use. The gun would not come up, or the game come clown. The fact was, that the shot barrel was only half the weight of the rifled, consequently the whole fabric was without balance, and to what I would my aim was invariably disconcerted.

Of the joints used in fly-rou?s the plain sliding one is probably the most convenient. If properly fitted it should never jam or work loose; but if I lived on 
a river I should never make use of any other than the simple splice, for the lashing affects less the action of the spring; and if a few additional moments are lost in putting it together, the return is ample recompense. But I fear the age is too fast for its adoption.

Having given my thoughts upon the rod I will now go to the reel. Of late years, at least since I was a boy, all kincls of mechanical inventions and appliances have been used to produce a more perfect reel: there are now to be obtained stop reels, multiplying reels, and reels with as many internal cog and other wheels as would start a clockmaker. Of these complicated aplaratuses beware, for they are franght with disappointment and rexation of spirit; the old simple click reel is the only one that deserves the honor of being attached to a fly-rod. Still, too much care and attention can not be deroted to their construction. Every serew and joint shonld be as perfectly finished as those of a gim from a firstcliss manufacturer. The barrel of the reel should be wide in proportion to its length, for you thus gain power or give line with greater freclom; mothing is more mosightly or more awkwarl than a long narrow-barreled reel. Brass is the metal usual- 
ly employed for their construction, but the newlyinvented aluminium bronze is infinitely to be preferred, for it does not corrode or discolor with the action of the atmosphere, and it is less liable to suffer from a blow or a fall; mischances that the fly-fisher's paraphernalia, more particularly in a rocky mountainous country, are especially liable to when following the course of a tront brook, for stones will be slippery and of treacherous foundation. Who among our expert salmon or trout fishermen can not remember having obtained a frightful cropper when precipitously following up or down stream a heary fish he was fast to? I do not require to tax my memory greatly to recall half-a-dozen such casualties.

There are varions metliods of attaching the reel to the rod. Of none do I approre so highly as that by which the reel is held fast in a shallow indentation by a movable band. In those cases where the butt is pierced, or the reel held on the rod by a brass band attached to it, which closes with $a^{\circ}$ screw, the nuts are constantly getting lost or loose, through the thread being worn out; moreover, the hand not unfrequently gets chafed by coming in contact with them.

On the subject of fly-lines there is great diversity 11 
of opinion. Of whaterer materials they are composed they should taper. IIair and silk I was at one time much in favor of; but, after a lengthened trial, I found one great oljection-the two materials har not the same amount of elasticity, so that a heary strain would bear more severely on one than on the other, which ultimately caused brittleness. A plaited-silk line, which has been submitted to a process of rarnishing, rendering it impervious to water, will, I think, do the greatest amount of work and throw the greatest length of line; but for delicate, light, fine fishing, nothing I know of can surpass the old-fashioned one, composed entively of horselair; for they are possesserl of more vitality, elasticity, and quickness. In the selection of one of these crery foot slould be carefully examined and tested, for a carcless, slop-shop workman will frequently work in short and worthless hair, possibly in the center, which will kestroy the whole fabric; for if the line be "once broken it is uscless. It matters not how much ingennity and time you spend over the splice. For a day or two it may pass through the rings, but the fivetion will weatr it rough, and it will catch, sooner or later, not improbalsly with a large fish, for then the strain is gratatest. Can any thing more disgusting 
be imagined than taking the last look at eight or ten yarls of your line, perhaps more, rapilly clisappearing in the eldying stream with your casting line and flies acting as adrance guard? The thought of such a catastrophe is enough to make a man's blood run cold.

Casting lines should also taper, and, provided the gut is good, can scarcely have too fine a termination. Although a great many disciples of the rou always purchase these ready-made, every fisherman should be able to knot one nip himself. The process is simple. Select your hairs-coarse ones for the top, fine ones for the bottom-steep ihem for some minntes in water, as warm as the hand can conveniently bear, then knot them together, increasing $\mathrm{or}^{\circ}$ diminishing gradually in size according to the end you liave commencel at. Care must be taken that such a knot be used as there is no slip to. The safest I know of is formed thus: take the encls to be joined and place them alongsicle one another, then take one end and mike a single hitch by doubling it back and passing the end through the loop, which pull tight. Do the same with the reverse encl, when by pulling on the line both will slip together, the strain having the tendeney to tighten the knot. 
After cutting off the surplus ends a few turns of very fine silk to whip them down and the smallest quantity of varnish, will add much to the appearance of the line. There is no amusement that I know of in which it is so requisite for the follower of it to know how to make use of his hands and his ingenuity. Bacl luck, or whatever you choose to call it, may, before an hour's fishing be done, reduce you to the alternative of either ceasing work or manufacturing out of broken fragments a new casting line. Very possibly this is caused by the fish being more than usually on the feed. How disagreeable to be compelled to halt!-better far to spend ten minutes with the dry end of gut in your mouth, the more rapidly to render the hairs fit for knotting, and to know how to put them together afterward.

The rings upon your rod should be large and not too numerous, five are sufficient for the lower joints, and about five more for the tip, supposing it to be a rod thirteen feet in length, and in three pieces. In America I lately saw rods ringed on both sides, so that if after unusual hard work and constant use a tendency to warp was evineed, you altered your reel to the reverse side and thus connteracted it. However, the better plan, I should say, would be to use 
the reverse sides day about. The only objection to this double arrangement of rings is additional weight, but that must be very trifling.

Haring now described the rod, the reel, the line, and the east, I approach a subject that I hesitate to touch, viz., fly-tying, for I do not believe that any one can become an expert, hut throngh constant practice, after having received a few elementary lessons from an adept. I beliere I can tie a fair fly; but how long do you suppose it was before I rearhed my present excellence? Years; and even now I discover wrinkles and new methods of which I was not previously aware; however, one rule may be laid down: never to take a turn of the silk round your hook without purpose, or without giving it sufficient strength to keep it in its place and perform the dnty intended. The most important part is the simplest and first, the securing of the gut to the shank of the hook. Unless this is attended to all your labor is rain and worthless-so much time thrown away and wasted. Here comes all the strain, and a thoughtless turn or two will canse naught but disappointment. Some anglers, particularly Irish ones, place the wings on so that the feather points from the hook, then double them back and tie them 
down. In this method much practice is necessary to form a handsome hcad; but its arlvocates claim for it strength. Howerer, I have so frequently fomm the silk slip, and the fuathers consequently point in the reverse direction, that I mulesitatingly condemn the practice. To make a handsome and serviceable fly, I have always followed the method of putting the wings on separately, care being taken not to injure the pile of the fiathers; and this should be done last, the most minute drop of rarnish being used orer the silk when the head is finished off. My first effort to tie a fly turned out a thing like a humming-bird, my second like a humble-bee, and so on till I have suceecled in making a goor imitation of a gnat. I'atience and persererance have done this, and none will ever exeel in fly-tying without exereising these qualities, so essentially useful in every walk in life. As a rule, the ligger the river, the more water it contains; and the more boisterons the weather, the larger the flies that are used; but insummer, when the streans amd lume have become clear and low, the smallest sizes must be resorted to, thrown with the lightest line, from the most moloservable ami most shelteresl position.

Three flies, their coloring and component farts, 
that I have found successful on almost all waters and at every portion of the open season, I will describe; in fict, I have so much faith in them that I invariably use all thrce in making my first essay on an unknown river, viz., the red hackle, hare's ear and yellow, and black hackle. In America, on the small trout-brooks, I found them equally attractive, evidence of a similarity of taste in fish on the Eastern and Western continents. Fly No. 1, the red hackle, body composed of rufus wool, twisted in with tying silk, lower portions of body to be fine, gradually increasing in thickness till the shoulder is reached. Shoulder of bright-red cock's hackle, the color that is obtained in a natural state from the domestic fowl, game fowls gencrally producing the finest; but if those from the East Indian jungle-cock can be obtained, you will possess the rery best. Wings put on separately, and obtained from the wings of the corn crake, shot immediately previous to their antummal migration. Fly No. 2, hare's ear and yellow; this has a tail composed of two strands from the larger feathers of the guinea fowl, body composed of the fine mottled hair off the cars of a hare, mixed with fine mohair, of any of the intermediate shades from straw color to olive. The mohair should be eut 
short, so that it will the better mix with the hare's ear. This dubling must also be ticd in with the silk, and the fly should be large at the shoulder. No hackle in this specimen is required. The wings from the large wing-feathers of the fieldfare, each placed on separately. Fly No. 3, black hackle; body of blue wool or mohair, fuished at termination with a couple of turns of silver tinsel, black hackle from domestic fowl for shoulder, with the wing composed of the feather either from tail or wing of the water-hen. The angler had better be provided with various sizes of these, as rivers are not always in the same condition, and weather is variable. For me to say that other flies will not kill better on some rivers, or at least equally well, would be absurd, but those described I have found most generally useful. A handsome and frequently very killing fly at times, particularly in blustering weather, is made of the following material. Body of two of the longest and most rufus strands of a feather from a brown turkey; theso strands to have the fingers pulled up them, so as to canse the fine edges to stand out; then wrapped firmly on. Shoulder of brown cock's hackle, with brown gronse feather for wing. In autumn, particularly if the stream should be clearing after a flood, I have 
known this fly to be most effective. Howerer, it is no bad plin if you are a stranger in a neighborhood, to get hold of a poor honest disciple of Izaik Walton, who will give you information, and rery probably sell you some of the contents of his book. Howerer, be. ware that he does not palm off upon you the débris of his collection. Except for sea-tront fishing, the brilliant and many-colored macaw-like compositions are totally useless in our inland streams, so let not love of gaudy coloring or the adrice of inexperienced persons induce you to spend your time and money on such fibrications.

We will suppose the norice accoutered with all that money and judgment can obtain in the shape of tackle and rod, at the same time hoping that his garments are composed of those sober quiet colors that are least obscrvable; for whether in shooting, deerstalking, or fishing, attention to this is all important ; that he wears naught that is not useful, and not like the Laocoon, as I once observerl a young gentleman, so covered was he with straps and bright-colored strings suspending lunch-box, and flasks, and innumerable other contrivances, the very weight of which must have impeded his morements and fagged him to death long ere the day was over. IIe is on the $11 *$ 
river's margin, at a spot free from bush, rock, or other impediment. The rod is carefully put together (I hope it is a spliced one, for I sha!l have more hope for the beginner's ultimate sucecss from this choice), the reel is attached, the line drawn through the rings, and the cast and flies carefully taken off lis hat, round which they have been wrapped (to make them more subservient and less obstreperous on commencing work), and marle fast to the line. Ere an attempt at the first cast is malle, take one worl of advice. Englishmen are so horsey in their proclivities that they invariably consider a rod, when first they handle it, an instrument to be treated and used in exactly the same manner as a carriage whip. From boyhood upwarl they have been nsed to the latter, and the Englishman's hand has obtained wonderful cuming in cracking the same. Now the two motions are essentially different; the one is performed by the quickest possible jerk, the other loy making the widest possible sweep, as fiee from angles as the turus on a race-course. Get this information so grafted into your brain that you will not be likely to forget yourself, for on each occasion of this forgetfulness you will pay a penalty by being minus a fly, probably the trail one. I have known some persons so 
skilled in snapping off flies, even although possessed of considerable experience, that their custom must have been of no small advantage to the tradesman who supplied them with tackle.

Supposing the angler is facing a river which he is desirous of throwing across. The rod being held in the right hand, gradually, but with increasing veloci$t y$, raise your rod from left to right; when the line is straight out from you, make a sweep, and bring the flies down upon the water with a half-circular motion of the hand. This last movement will raise the slack of the line and cause the trail fly to strike the water first, which should always happen. When this first lesson is thoroughly learned with the left hand, it should then be practiced up and down stream: when, with persererance and attention, such precision may be gained that the fisherman can place the flies at every effort within an inch or two of the desired spot. 


\section{STRONG SHOOTING.}

Do guns of this day shoot better than those manufactured ten years ago? The reason why I propound such a question is, that I hear and read of birds being killed steadily at seventy and eighty yards, of trapshooting being practiced with a fifty yards' rise, and the performers scoring four out of five. I never lived in a neighborhood where it was not reported that there was a wonderful shooting gun, but I never have had the fortune to see any of them perform their umprecedented feats; either the shooter's nerves were out of order or the powder was bad. How unfortunate it is that powder will so often be bad, more especially when it is desirable that it should be excellent. When I hear sportsmen, particularly the young gentlemen, narrate the performances of their double barrels, I can not help commiserating myself that I have never been able to obtain better than a third-rate article for my use, for I have heretofore thought the gun which killed reliably at forty and 
with considerable certainty at fifty yards was as near perfection as obtainable. I do not mean to say that occasionally a snipe, or even a duck, has not been turned over at serenty yards, still at such ranges I have aiways thought the odds very much in faror of the birds. As none of my old battery can accomplish more than above stated, before $I$ go abroad again it would be desirable to obtain a modern gun, yet I should not like to adopt a new favorite, which would shelve an old, without tirst seeing him perform, but if the novice will kill steadily at seventy with ordinary gunpowder, such as C'urtis and Harrey's, I shall not have a moment's hesitation on the subject; therefore I ask, do modern guus shoot much better-say thirty per cent. better-than those turned out ten years ago? 


\section{IDEAS ON DOG BREAKTNG.}

How many that would have turned out good men and useful members of the community, have been ruined in their youth tirongh not being nuderstood, and possibly treated with undue severity? How many promising colts, perfect in general appearance, liave turned out lumaways, apt to shy, and possessed of every failing that it was possible for horseflesh to learn, therefore irrecoverably ruined, throngh the bulJying and barbarity of the trainer? As men are mined, as colts are ruined, so are a preponderating pereentage of our pointers and setters. My old Dominic used habitu ally to go about with the end of his strap langing out of his pocket; no ordinary strap, but what the reader might imagine a conple of feet cut ofl an omnibus trace, terrible only to behold by such as were fond of toffey, or eneased in tight-fitting jackets. And then the possessor of this strap was no puny bookworm-no, not he-but a stalwart Celt with a biceps so trementous that his wife, proud of 
his manly development, used frequently to ask her friends, her female ones of course, when discussing the relative merits of husbands, "IIare gou erer seen William's muscle?" I don't know that I ever saw it; I an certain that $I$ often felt it, and believe now that I would have been much better informed, and at that period more devoted to my books, but for the whackings that no excuse, whether just or not, could save me from. So it is with the majority of dog-breakers, they invest their surplus cash in the purchase of the mest formidable whip that can be found, and with it conspicuously displayed fiom the yawning pocket of their velveteen coat strut about in conscious pride, and are at once dubbed dog-breakers; and truly they are $\log$ breakers, if breaking the heart and spirit of por canines deserres the appellation.

The dog I have found much like the child; study his character, mark his eccentricities; when he does wrong gently admonish him, when he does well, withhold not the approbation meriter. Of course in both races a headstrong pupil will eccasionally be found, when castigation becomes necessary. With this I can find no fault, but I am persuader that unnecessary correction is too often administered to both. In the course of my life I hare possessed a great num- 
ber of pointers and setters, the majority of which I have broken, and not giving myself undeserved praise, I have had among the number dogs which I have seldom seen equaled, never surpassed, and why? Simply because I through kindness got my pupils to love me, to repose confidence in me, and never caused them to suppose that their love was misplaced and their confidence trespassed upon. No, no, neither is the strap the necessary adjunct of the schoolmaster, nor the dog-whip that of the instruetor of the deroted, unselfish, enduring, and persevering companion of man. The dog, like the child, is possessed of affection, which can easily be won if the proper means are used, and affection alone will induce both child and dog to do all in their power to serve the object of their adoration.

Probally the most important point to be attended to is that the material you go to work on be well bred and well made. In a puppy two or three months old the latter is no easy thing to tell, for it is really extraordinary how they change; but if, on the other hand, he should be nine or ten months, and possessed of the following points, you may go to work with the prospect of your labor not being thrown away: Medium size, short back, strong couplings, and well 
ribbed up, feet and limbs large, eyes high and intelligent. This last is perhaps not so absolutely necessary, for I have seen dogs with the most washy-looking daylights possessed of wonderful sagacity, particularly anong spaniels and French poodles, but I can not consider it other than a great defect in their personal appearance. Above all things, avoid a youngster with a curly tail. I know nothing more unsightly. The last, although the most requisite, desideratum is to know that the pupil possesses a good nose. When very young this is not so easy to fincl out, still with attention to the rapidity with which he notices tirlbits of bread or meat, a probably correct opinion may be come at; but when of mature: age, say old enough to be shown game, if when 1 unting he carries his head well up there can be no longer room for doubt that his olfactory nerves are all right.

Your field language should always be th: same, and each command be expressed by a word of one syllable, the words being as dissimilar in intonation as possible; but it is better far to do without the voice by substituting the whistle. At all events nerer speak to your dog while hunting unless absolutiiy necessary. In early education I always aceomfany each order with a movement of the hand; for in- 
stance, in saying "clown" I hold up my right hand. In a short time the holding up the hand alone is sufficient. In quartering your gromed, if your dog is far ahead and you wish him to hunt either to the right or left of his present position, with one note on the whistle attract his attention, then turn in the line you wish him to hunt, at the same time waving your hand in the desired direction. Before long, with a note on the whistle to make him look towarl you, a wave of the hand will be all that is necessary to cause him to alter his course to that which may be wished.

All well-bred dogs will stand game. I believe they do it for the purpose of ascertaining the exact position of the birds, that by a sudden direct rush they may have a chance of capturing one. To prolong this pinse is the important part of the youngster's education, and for that purpose the checkstring is to be used. A plan that I have adopted with the wreatest suceess is the following:-Procure some game birds, I generally nse quail, pluck the fuathers from one wing so as to restuce their power of fight: llope them at different places in a grass field, marking within a few feet of the spot with a piece of paper, then give the birds ten or filteen 
minntes' lair, so that they may get over their fright and move abont.

Tine being up, take your pupil, with check-string made fast to him, and hunt him up wind. As you approach where a bird has been deposited, cantion him, appear to be anxiously expecting game, your manner will make him doubly cautions, so that when he winds the game he will give you credit for more capability of finding than himself; your ability will be appreciated, which will be shown by the desire he will manifest in carrying out your future orders; but having come up to the birds, when the dog stauds tighten the check-line, bearing heavily against him if he appears determined to be headstrong, cautioning him in a soothing, confidential tone, and the instant the bird flutters up give him a sharp jerk and cause him to "down," as if the departure of the bird was his fault. Three lessons of this kind, given with care and proper attention, the pupil being at the proper stage in other respects, I have always found sufficient to make him steady on his point.

Why I disapprove so much the use of the voice, is founded on two reasons: first, that it is more alarming to game and more apt to cause them to be wild than any other sound, not eren excepting the report 
of the gun ; secondly, if you keep constantly speaking to your dogs, from hearing incessantly your voice they become so used to it, that in emergencies they will fail to give it that prompt attention so desirable. I always teach my setters and pointers to retrieve both by land and water; with the former breed this portion of their education I have never had any difficulty to impart, with the latter I have in one or two instances found a most decided antipathy to the aquatic portion, yet I have always succeeded in the end by following this plan. When the weather is warm take the youngsters with you bathing, with one or two more aged and previously instructed companions, wade some distance out and then call them; if you have gained their affection they will ultimately come; if you can do so without alarming them caress them when in the water, and give them a small piece of food. After getting the pruppies to wale till nearly out of their depth, cross deeper water, and if they will not come at first, hide yourself, occasionally calling them; I never knew an instance in which they would not nltimately eome, more particularly when they see the example of their more aged companions. A few lessons of this sort will give them confidence, 
and after instructing them to retrieve by land, they will do the same from water.

Some dogs have a natural tendency to retrieve; with such there will be no diffieulty, while others take a long time to comprehend what is desired of them, one pupil that I possessed coud not be tempted for a length of time to take any thing in his mouth and cirry it. For days I tried to overcome this repugnance till my patience was almost exhausted; at last I adopted a new plan and found it successful, I attached a long string to a ball and after rolling it from me, he would go and nose it, but do no more; when he was about to leave, by pulling the ball his curiosity became exciter, and he would then lay hold of it. Repeating this, it awakened a desire to retain it, and at length, as if in sheer opposition, he would keep it in his mouth and carry it with him. With others I have tried the same course, and always successfully. I do not consirler any $\log$ of these breeds perfectly broken that will not retrieve from both elements; and although I know that in England it is not generally considered a necessary part of their education, the advantages are so obvious that it does not neerl further cumment. At four or five months old you should commence to handle your youngsters. Ac- 
custom them to the roads, it will help to orercome their timidity and assist in hardening their feet. At six or seven months they should be familiar and consersant with the more simple portions of their edncation, such as "lown," "heel,"\&c.; and at about ten months game can be shown them; but on no account permit them to do a day's work, or exhaust themselres in hunting, till six or seven months more are orer their hearls. As to speed, it is a common supposition that if a log have a good nose he can not have too much speed; but very fist logs are apt to run over game, and consequently flush it from the very rate they are moving at. I have olserved also that those who will do the longest and sererest day's work are less impetuous as a rule than others. When shooting regularly, the dogs in use should always be kept in their kennel except when in the field; their associating liberty with their work makes them more zatous am anxious to please. On hunting days one good substantial uncal, immediately after reaching home, with a piece of onten or coarse bread in the midelle of the day, will le fomm the best working aret; a dog with a full stomath is in a most mutit state to be used.

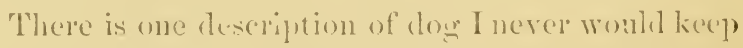
in my kennel, viz, vane that trails his gyane. Sune 
persons recommend an artifice to make him hold his head up, which is in my opinion all nonsense, because the fault lies in the animal being lefective in seenting powers. But even if such should not be the case, and they are capable of finding as much game as the $\log$ who ranges with his hear up, yon will not have the same sport, for although game may lie well to the latter, they certainly will not to the former. The birds possibly argne thus, "that harum-scarum fellow with head up, slashing along after some important business to the other side of the field, is too preoceupied to mind us; as long as we lie close, there is nothing to be feared." But, on the other hand, the inquiry (if birds talk to one another) will be made by some sagacions old paterfamilias, "What's that pottering dog doing down there?" All eyes are immediately directed to the disagreeable intruder in question, and rery soon it becomes a decided point among the feathered family that their footsteps are being followed, and that with felonious intentions, and in preference to waiting for further information they wing their way to safer retreats. It is not becanse birds and quadrupeds don't talk that they don't think, particnlarly wild ones, when it is on a point regarling safety. When young logs are 
so jealous and headstrong that they will not back one another, it is well to use them separately, along with an old and stanch farorite. A point being obtained by the senior, let the younger approach him as close as, if possible, for him to see the old dog, then make him down charge, by raising your hand, and kecp him in that position till your barrels are reloaded; but if it be attainable, the elder dog being the farthest ahead, call up the pupil and give him the wind, afterward slowly approaching where the first point is made, showing by both manner and voice that you are on the qui vice, and do not let his pace be faster than your own till the elder dog is reached, when any attempt to outstrip or go ahead of the proprietor of the find, should be instantly corrected. With a little patience and repetition of these maneurers success will be the result. I can not recommend, however, the practice of constantly hunting old and young dogs together; for the former, fiom greater experience, will find more game, and the latter sceing this will begin to disbelieve in his own powers, and follow the veteran, that he may always be at hand when sport is obtained.

The report of the gun should invariably be the signal for dogs to drop to shot; this lesson should early' 
be inculeated at home. To familiarize the dog with the gun I have been in the habit of taking a pistol with me to the kennel, and all the youngsters being called into the yard, fire it, making all drop to shot; after having kept them a sufficient time down, I would cause the food to be brought in, and with a wave of the hand permit, them to rise and have their grub. To have to shout "down," keeping an eye at the same time on each of your dogs so as to enforce the order if necessary, is very unsportsmanlike, and certainly very much out of place when all your power's of vision and observation are indispensable to mark where the departing covey are going to pitch, or the dead and wounded drop.

When seeking for a wounded or killed bird never allow your dogs to know that you have been unsuccessful : if you have given as long a time as you can spare for the purpose and see no ultimate prospect of finding, take one of your bagged birds and drop it when the $\log$ is engaged, then cast back that he may wind it, and thus believe that his search has not been fruitless.

The setters most in vogue at the present day I do not like nearly as much as those that were preferred fifteen year's ago, for this reason, that they appear to 
me too seedy; such of course may suit the person who only shoots a few hours at a time, and then over highly cultivated level land, but the sportsman who goes in for work, who shoots for shooting's sake, and not simply to get up an ap'petite, to whom every day that he is out is too short, would, I am certain, fiurl more satisfaction in the representatives of the old school. Some time since so decply was I impressed with this irlea, that I crossed some of my stock with a well-bred, but rather large cover spaniel; the result was that the second cross were not only hantsome, but animals that there was no end of work in, with great artivity and energy.

It frequently happens that among a lot of youngsters you will find one most provokingly backwarl, who won't hunt or take any interest in the procecelings. Put a curb on your temper and have patience. You may have to wait, but gradually the apathy will wear off, and ultimately he may turn out the flower of the flock. I remember a youngster, which mutil he was eighteen months old, refirsed to take notico of game. Two or three times a week, for months, he saw birds killed, yet all was ineapable of imbuing lim with the proper spirit, for he would scarcely ever leave heel. At length the ice was broken. He got by ac- 
cident among a covey, which his experience told him he would flush if he moved, and from that day a new era commeneed in his life. But this is not so much to be wondered at. Can not all of us remember some contemporaries at school who were supposed to be almost wanting common sense, but who, ultimately, turned out brilliant men? Intellect is not equally rapidly developed in each, and precocity is not always the precarsor of brilliancy in mature life.

IIaving said thns much about our farorites, I can scarcely lay down my pein without expressing an ilea or two on the lords of che ereation. Bad sportsmen never have good dogs. The fussy, nervous, excitable person never has good dogs. It is a moral impossibility that they can be so, although they may have been most perfectly broken. In such hands they are certain to retrograde in performance, in the same way that the regiment that is perfect in its drill when under its cool and eollected colonel, becomes a rabble under the irate, iraseible, nervous major. "Kieep cool" should be your motto; for if you can not, your success will ouly be mollerate. Nothing is so destruetive to both dogs and suecess as hurry. Listen in conclusion to the advice of an old and excellent sportsman, and you will see that his ideas much coin 
cide with mine :-Above all things never permit yourself to be hurried; but when using youngsters, yes, and even old and tried dogs, perform your loading and duties with as much accuracy as a soldier upon parade, remembering that the loss of a crippled bird is nothing to spoiling a valuable $\operatorname{dog}$; for those which have courage and energy, and consequently the most promising, will, from such neglect, be the most liable to suffer. 


\section{WILDERNESS IIFE.}

Cincumstaxces had caused me to attach myself to a trader, who, with about twenty teamsters, was en gonte for northern Mexico. My dnties were to hunt and supply the party with game, a pleasant enough occupation but not withont danger, for the greater portion of the comntry we trarersed belonged to the much-riearerl Comanche, the most reckless race of freebooter's and horsemen probably on the face of the earth, who are at war with every one, and prize nothing nore than a white man's scalp. Knowing such to be the ease it behooved me to keep my weather eye open when separated from my newly-formed acquaintances, but for all my watchfulness I several times had narrow escapes. Still time fled pleasantly onward, and as I write this I look back with delight to the haply, fiee, thoughtless hours passed either in the saddle or watching the movements of the will animals that knew no bounds to their demesne. The Indians sel. dom troubled my thoughts, for I had a mare, that 
I daily rode, handsome as a picture, and as game, fleet, and endurirg as any animal I had ever thrown a leg over, thorougli-bred I believe, and as sagacious as a dog. Between her and my bat inule there existed a most extraordinary affection. I har but to go aheal, and the latter was certain to follow, so if I dirl not fall into an ambuseade I knew full well I could distance any Comanche braves till I regained eamp, where, behind the wagons backed by the stalwart Missomian teamsters, who well knew the use of their rifles, I would be safe. Unfortumately the principal of the expedition was a most unpleasant and mopopular person, so that between his bullying and his unpleasant manner, a mutiny was raised among his retainers, and the eonsequence was that the majority started en masse on their own hook, to seek another employer, or find their way lack to their native State.

My education and antecedents had been such as to grive me a horror of mutiny; moreover, np to this date, I had nothing to complain of, so I deternined to stick to the wagons, and use erery effort in my power to save the owner from the only alternative that appeared left, the deserting of all his property in the wilderness. Ere long, however, I was com- 
pelled to change my resolution, for no one could submit to his irascible temper and constant insulting language; so, with no companions but my mare and mule, I left the camp, one bright morning in the month of February, with the determination of returning eastward alone. The step was full of danger, but I preferred running the risk rather than remain to be further insulted, or seek redress by recourse to weapons, too often done in this lawless portion of the world.

As the teams were being hitehed up I started in the reverse direction, little aware of the trying ordeal that was before me. My animals were in good condition and spirits.

For a week I traveled northeast, in the hope of finding a suitable halting-place to remain in till spring fairly commenced. At length I came upon a spot which took my fancy-a small table-land well sheltered from the northern wind, and underneath a valley, from which the snow had partially disappeared, and where there was a fair quantity of bunch grass, the most desirable food for the quadrupeds. Under a projecting rock I male my camp, for the spot was so inclosed that I hoped the lighting of a fire would not attract attention. W'eeks rolled by, and the mare and mule lost little of their 
condition, although the weather was frequently pinching cold. The cañons in the neighborhood supplied me with abundance of game, and each day I expected that a break in the weather would justify a start for the eastern settlements. Of course one day was only in outline a repetition of the other, but how widely different in detail. In the morning the horses were taken to the bottom, breakfast was cooked, the enjoyable pipe lit, and the direction settled in which I woukd hunt, returning earlier or later, according to success. The afternoon would pass mending moccasins or clothes, cleaning arms or arranginis camp, procuring firewood, till it was time to hunt "1p the nags, which being accomplished, and the evening meal dispatched, on a bed of leares I would smoke myself to sleep, painting pictures of distant home till no longer conscious. A hunter's camp always becomes a rendezvous for two or three wolves, and two of these scoundrels were seldom beyond sight. Latterly they became so tame that they would come close enongh to pick up a bone if thrown to them, and one night when the cold was more rigorous than usual, on a waking to ard fresh fuel to the fire, I saw one of them sitting besile the warm embers, nodding his liead like a sleepy listener to a prosy sermon. Every 
day I expected to be able to set out. The appenrance of the sky denoted change as I turned in on the last evening, but whether it was anticipation of the good things to be obtained when eivilization had been reached, I know not, or an unaccountable consciousness that danger was not far distant, I could not sleep. First I tried one side and then the other, but withont effect. $\quad$ s it was not cold the fire har gradually decayed till only a few embers remained, m.king the surrounding darkness more intense. While I was hesitating whether the rebuilding of the fire or a fresh pipe would induce sleep, uneasiness seemed to have taken possession of my animals. The mule was as watchful as a dog, and as I knew he would not leave his ficiend, I invariably left him mtied. Several times he uttered that short, quick snort so peculiar to the species, and alwass indicative of alarm, while the mare kept moring as far as her lariat would permit her. It might be any thing, from a deer to an Indian, so as my arms were at hand, I quietly crawled ont of my lair, taking special caution that no momentary flicker from the fire should disclose my movements, and by a short détour got beside the nags, and soou hard the soft, silky muzzle of Beckey in the palm of my hand. The great- 
est disaster a man can suffer in such a sitration is the loss either of his ammunition or of his horses. If there were any hostile redskins in the neighborhood, by the step I hat taken a stamperle of my animals was now impossible. $\Lambda$ few of the longest hours I thus sat, my presence reassuring the beasts, and, when day broke, so still had all become, that I doubt not I should have been asleep, only that the hour preceding day is well known to be invariably the time selected by Inclians to carry out their machinations. In the morning, quietly moving about camp, as if pursuing unsuspiciously my usual arocations, I particularly examined the locality, when, among the remaining seattered patehes of snow, the easily-distinguished bruised moceasin track of an Indian was discorered, doubtless made by a brave, who in search for game had got benighted, when he har stumhled across my hiding-place. My eamp was therefore no longer safe; the coming night, he, with his companions, would be back, when woe betile the solitary white man. My horses I aceompanied to their feeding-ground, not permitting them to get beyond control, and as soon as their appetites were sutliciently satisfied, I returned to my little home for the last time. The few trifles I possessed were 
soon packed, and nothing remained further to delay me. Still I waited a quarter of an hour longer, for the purpose building a pile of wood, in which I placed some smoldering embers, in the hope that it would not blaze up till several hours after dark-an indication that I doubted not the redskins would construe into a certain evidence that I was still ignorant of being discovered. On my arrival in the Bayou my mare had been a little tender in firnt from her hoofs having been worn very close; the period of rest had rectified this, and, full of hope and anticipation, I pushed my way eastward, the ouly regret that passed like a cloud orer my mind ocenrring as I took the last, ay, and long look, at my wilderness home. 



